\title{
Big Tobacco and the human genome: driving the scientific bandwagon?
}

\author{
HELEN M. WALLACE ${ }^{1}$
}

\begin{abstract}
The tobacco industry first began to promote the idea that a minority of smokers are 'genetically predisposed' to lung cancer in the 1950s. We used tobacco industry documents available as a result of litigation to investigate the role of the tobacco industry in funding the 'scientific bandwagon' described by Fujimura, in which genetics has come to dominate the cancer research agenda. From 1990-1995 inclusive, $52 \%$ of the project funding allocated by British American Tobacco's Scientific Research Group went to genetic research, mainly based in universities and at one cancer charity. The largest project involved a pharmacogenetic research unit, based in a UK medical school, which was established with the help of tobacco industry PR consultants in 1988. The unit received half its project funding from the industry in 1992. Its main aim was to identify a minority of smokers who are supposedly 'genetically susceptible' to lung cancer, so that smoking cessation measures could be targeted at them. This aim was adopted and promoted by influential scientists at the US National Institutes of Health and the UK Medical Research Council in the late 1980s, in the run up to the Human Genome Project.

BAT's research funds were also used to counter claims by others to have identified a unique 'genetic fingerprint' for tobacco smoke in lung cancer cells. We conclude that the tobacco industry has played a significant role in shaping research agendas, in particular, by promoting the idea that individual genome screening would be of benefit to public health.
\end{abstract}

\section{Introduction}

Tobacco smoking was responsible for an estimated 3 million deaths worldwide in 1990 , predicted to rise to 10 million by 2030 if present trends continue. ${ }^{2,3}$ The tobacco industry has a long history of funding research into the health effects of tobacco as part of a sophisticated legal and public relations strategy. ${ }^{4,5}$ Its strategies on Environmental Tobacco Smoke (ETS) and nicotine have been discussed elsewhere ${ }^{6,7,8,9,10}$ but we are not aware of any detailed examinations of its funding of human genetic research.

Fujimura (1988) describes a "scientific bandwagon", which "exists when large numbers of people, laboratories and organizations commit their resources to one approach to a problem". "She describes how, by 1984, molecular biological cancer research became a line of research that scientists increasingly joined in order to build successful careers. The bandwagon was driven by major investments in infrastructure and very large increases in funding allocations, particularly from the US National Institutes of Health (NIH). 
However, the NIH were not the first or only funders active in this area. From 1954 to 1999 the Council for Tobacco Research (the CTR, formerly the Tobacco Industry Research Committee) was the main tobacco-industry-funded research body worldwide, and genetics played a central role in its $\$ 20$ million a year research programme. ${ }^{12}$ By 1994 , the CTR was one of the largest private funders of medical research in the USA and had awarded nearly $\$ 225$ million to approximately 1,000 researchers, sponsoring "pioneering work in identifying familial cancers, the role of genetic factors in cancer formation, and the identification of oncogenes". Its first director, Clarence Cook Little, was a eugenicist who promoted the idea that there might be a gene that both leads people to smoke and predisposes them toward cancer, implying that the statistical link between smoking and lung cancer was not causal. ${ }^{13}$ To support his position, Little used a 1957 paper by the British statistician and eugenicist Sir Ronald Fisher, published in the British Medical Journal. ${ }^{14}$ In 1958, following a letter from Fisher to Nature ${ }^{15}$ the New York Times reported that Fisher was a "consultant statistician to the tobacco manufacturers". 16

Although Fisher's theory no longer commands scientific support, ${ }^{17}$ genetic predisposition to lung cancer is still a topic of active research. It is possible that such research may help to elucidate the molecular mechanisms underlying cancer. However, some researchers have also claimed that genetic screening will one day predict which smokers will get lung cancer, allowing smoking cessation measures to be targeted at this minority of individuals. Claims to have developed a genetic test which "apparently distinguishes cigarette smokers whose genes make them prone to lung cancer from those resistant to developing the malignant tumour" were first made in the New York Times in 1973, ${ }^{18,19}$ by researchers who were seeking (and subsequently received) funding from the CTR. ${ }^{20,21}$

However, this hypothesis is not supported by twin studies, which suggest that lung cancer has no significant inherited genetic component and that therefore there is no possibility of a genetic screening test with high clinical utility. ${ }^{22,23,24}$ Further, because many diseases are caused by smoking, ${ }^{25,26}$ all smokers benefit from quitting, whatever genetic variants they have. Genetic testing in clinical practice would therefore provide no additional useful information for physicians and could mislead individuals about the risk of smoking. ${ }^{27}$

Hall et al. (2002) argue that the tobacco industry may have an interest in using the possibility of genetic screening for disease susceptibility to convince ambivalent smokers that they do not need to quit. ${ }^{28}$ This theory is consistent with a 1996 memo from the director of media at PR firm Burson-Marstellar to Philip Morris, which puts the marketing case for the tobacco industry to undertake this type of research:

"A simple test might eventually be devised to tell a smoker whether or not he is at risk. This would put the burden of any consequence from smoking on the individual, and would clear the way for the non-susceptible population to smoke with a clear conscience". ${ }^{29}$ 
Although the CTR ceased to exist in 1999, British American Tobacco (BAT) continued to fund academic research via its Scientific Research Group (SRG), including research on genetic predisposition to disease, until at least $2000{ }^{30} \mathrm{We}$ therefore set out to detail the role of the SRG in human genetic research, using BAT documents released as a result of litigation, supplemented with related documents released by the CTR and by Philip Morris. We aimed to identify what research had been funded and why, and the influence of the tobacco industry on the research agenda.

Whilst the tobacco industry may see promotion of genetic screening of smokers as advantageous to its business, it may perceive other genetic health research as a threat. In 1990, researchers began to link the pattern of damage in the p53 gene in lung cancer cells with benzo[a]pyrene, a constituent of tobacco smoke, and by 1996 Denissenko and colleagues had demonstrated an in-vitro effect. ${ }^{31,32,33}$ The prospect of a unique 'genetic fingerprint' for tobacco smoke in lung cancer cells has implications for the financial liability of the tobacco industry. Bitten et al. (2005) investigated the tobacco industry's response, showing that the industry conducted research which appeared to cast doubt on these findings. ${ }^{34}$ Our research, which overlaps with theirs, also sheds some further light on these developments.

\section{Methods}

Our primary sources were documents made publicly available as a result of past litigation settlements. In 2001, we visited the BAT depository at Guildford to identify the scientific research projects funded by BAT's Scientific Research Group (SRG) during the 1990s. We used the search terms: "Scientific Research Group"; "SRG"; the names of the BAT employees responsible for the SRG ("Proctor" and "Boyse"); and, in secondary searches, the names of researchers and consultants funded by the SRG. We collected more than 800 documents in total during 10 days at the repository, including SRG meeting minutes, contracts, newsletters and notes of visits; grant proposals, reviewers comments and progress reports; BAT memos, notes and letters; and letters to BAT.

The document set is not comprehensive due to limitations in both the supply of documents and their indexing, and the difficult logistics of obtaining access to the documents at Guildford. ${ }^{35,36,37}$ Making an exact catalogue of documents proved difficult, as documents with different Bates Numbers are sometimes copies of the same original and in some cases the distinction between single and multiple documents may be somewhat arbitrary. However, the SRG budgets we identified contain partial information for 1989, complete figures for 1990-1995 and projected figures for 1995-1997, allowing us to make an analysis of BAT's research funding priorities from 1990-1995 (see supplementary material, S1).

To obtain a fuller picture we conducted additional searches of two further tobacco industry websites using the names of researchers and consultants: the Council for Tobacco Research USA, Inc. (the CTR) ${ }^{38}$ and Philip Morris (PM). ${ }^{39}$ We omitted researchers and consultants primarily involved in nicotine research or environmental tobacco smoke (ETS). Our search terms and a summary of the additional documents 
we identified are given in Table 1. The presence of documents in the CTR and PM files does not necessarily indicate a link between the company and the named researcher. For example, documents may include copies of published papers; newspaper articles; notes on conference presentations; or research proposals that have been refused.

Table 1: Summary of CTR and PM documents*.

\begin{tabular}{|l|l|l|}
\hline Search term & $\begin{array}{l}\text { Number of CTR } \\
\text { documents }\end{array}$ & $\begin{array}{l}\text { Number of Philip } \\
\text { Morris documents }\end{array}$ \\
\hline Idle JR & 460 & 304 \\
\hline Daly AK & $20^{\dagger}$ & $8^{\ddagger}$ \\
\hline Rothschild H & 194 & 196 \\
\hline Springall A & 1 & 467 \\
\hline Carter ND & None & None \\
\hline Cooper DN & 4 & 13 \\
\hline Currie G & 1 & 5 \\
\hline Poulsen H & None & 1 \\
\hline Clausen J & None & 9 \\
\hline Stell PM & 11 & 21 \\
\hline Field JK & None & 13 \\
\hline Farmer P & None & 47 \\
\hline Parry J & None & 83 \\
\hline Feinstein A & 108 & 1384 \\
\hline
\end{tabular}

* Documents relating to different individuals with the same name have been identified and omitted from these totals. Documents with different Bates Numbers are counted as distinct, even if they are copies of the same original. In some cases PM documents are copies of CTR documents.

$\dagger$ All but 2 overlap with Idle JR.

\$ All but 3 overlap with Idle JR

By checking funding applications and their response, we established that two researchers (Idle and Rothschild) had received research funding from the CTR. A detailed analysis of these documents is included in this paper. Idle also received funding from Philip Morris, mainly for work on ETS which is largely omitted from this paper. The consultants J. Parry and A. Feinstein received funding from Philip Morris and from the CTR respectively. We used these documents to establish the extent of their tobacco industry links, but did not examine these projects in detail. Springall was a commercial consultant to BAT (not an academic researcher) so we did not investigate the PM documents listed in his name.

We then searched PubMed ${ }^{40}$ for journal articles published by the researchers listed in Table 1 (omitting the consultants Feinstein and Parry). We used the documents to provide an overview of the SRG's aims, objectives and relationships with researchers and consultants; to quantify the cost and duration of each research project and the importance of genetics in the programme; and to examine funding declarations on journal articles. We also produced two detailed chronologies of the involvement of BAT-funded researchers in research on 'genetic susceptibility' to lung cancer and one on p53 mutations in lung cancer cells (see supplementary material, S2, S3 and S4), 
and analysed the role of these researchers in the development of the scientific bandwagon described by Fujimura.

\section{Results}

\section{The $S R G$ - aims and objectives}

BAT's Scientific Research Group (SRG) was formed in $1986 .{ }^{41}$ A key objective was: "To maintain a detailed awareness of, and an ability to respond to, scientifically related regulatory issues that impact on cigarette use". ${ }^{42}$ Research proposals were assessed by BAT not only for their scientific merit, but also for their contribution to the agreed strategic objectives of the BAT group. Future strategies for research were developed as issues arose and in 1993 gave particular emphasis to seeking "confounding factors" in the associations between both active and passive smoking and lung cancer and heart disease. ${ }^{43}$ The SRG considered "genetic predisposition" to be one possible confounding factor, along with other factors such as diet.

\section{Contracts}

BAT funded both consultants and researchers via the SRG. Researchers signed contracts with the British-American Tobacco Company Limited. ${ }^{44}$ These contracts allowed them to publish at the sole discretion of themselves and their research institutes, but required them to send copies to BAT at least 28 days in advance. BAT reserved the right to terminate grants at any time if the research programme did not follow the proposal.

The consultants reviewed research proposals for the SRG. Although most were medical researchers based in universities, they signed contracts with BAT which committed them to safeguarding the "best interests of the Company". ${ }^{45}$ In 1993, BAT's consultants on molecular biology and epidemiology respectively were Professor James Parry (University of Wales, Swansea) and Professor Alvan R. Feinstein (Yale). ${ }^{46,47}$ Feinstein had a long history of involvement with tobacco industry research, including funding for "special projects" determined by tobacco industry lawyers. ${ }^{48,49,50,51}$ Parry, who was receiving project funding from Philip Morris in 1998, was described as having a "long-standing relationship" with the company, and had recently applied for a new grant. ${ }^{52}$ Both Parry and Feinstein were editors-in-chief of academic journals whilst employed as BAT consultants.

\section{The SRG - funding priorities and journal publications}

The SRG budgets we obtained were complete for the period 1990-1995, as detailed in the supplementary material, S1. Most of the SRG's research budget during this period $(60 \%$ or $£ 1,570,600)$ was spent on projects based in UK universities and associated hospitals or research institutes, including one cancer charity. The remainder was spent on projects undertaken in overseas universities $(26 \%)$ or by UK consultants $(13 \%)$.

Whilst research on nicotine (24\% of funding) and ETS (12\% of funding) were clearly of high importance to BAT, genetic research, mainly into cancer, was more important - receiving $52 \%$ of the total $£ 2.6$ million allocated for $1990-1995$. 
Table 2 outlines the genetic research projects funded by the SRG for the period 19901995. Where indicated, projects extended before or after this six-year period, receiving additional funding. We have divided this genetic research broadly into two types:

(i) research into whether some people are more genetically susceptible (or "predisposed") to some diseases - particularly lung cancer - than others;

(ii) research into the genetic damage caused by tobacco smoke and other factors, and the molecular mechanisms leading to cancer.

Table 2: SRG Genetic Research Projects 1990-1995

\begin{tabular}{|c|c|c|c|c|c|}
\hline Project & $\begin{array}{l}\text { SRG } \\
\text { Funding } \\
1990- \\
1995\end{array}$ & $\begin{array}{l}\text { Earlier/ } \\
\text { Later } \\
\text { Funds }\end{array}$ & Institution & $\begin{array}{l}\text { Lead } \\
\text { Researcher } \\
\text { (dates) }\end{array}$ & $\begin{array}{l}\text { Number of } \\
\text { publications } \\
\text { acknowledging } \\
\text { BAT-funding }\end{array}$ \\
\hline \multicolumn{6}{|c|}{ Genetic susceptibility projects } \\
\hline $\begin{array}{l}\text { Cytochrome } \\
\text { P450 poly- } \\
\text { morphisms }\end{array}$ & $£ 429,200$ & Yes & $\begin{array}{l}\text { University } \\
\text { of } \\
\text { Newcastle } \\
\text { Upon Tyne }\end{array}$ & $\begin{array}{l}\text { Prof JR Idle } \\
\text { ('89-'93) } \\
\text { and } \\
\text { Dr AK Daly } \\
\text { ('94-'96) }\end{array}$ & $\begin{array}{l}\text { Sixteen, }{ }^{53,54,55,56} \\
, 57,58,59,60,61,62,63, \\
64,65,66,67,68\end{array}$ \\
\hline $\begin{array}{l}\text { Human } \\
\text { genetics of } \\
\text { lung cancer }\end{array}$ & $£ 80,000$ & Yes & $\begin{array}{l}\text { Louisiana } \\
\text { State } \\
\text { University, } \\
\text { USA }\end{array}$ & $\begin{array}{l}\text { Dr H } \\
\text { Rothschild } \\
\text { ('94-’96) }\end{array}$ & None identified \\
\hline $\begin{array}{l}\text { Segregation } \\
\text { analysis }\end{array}$ & $£ 72,700$ & No & $\begin{array}{l}\text { None: } \\
\text { Consultant }\end{array}$ & $\begin{array}{l}\text { Dr A } \\
\text { Springall } \\
\text { ('91-'93) }\end{array}$ & None identified \\
\hline $\begin{array}{l}\text { DNA poly- } \\
\text { morphisms } \\
\text { in } \\
\text { hypertension }\end{array}$ & $£ 36,500$ & Yes & $\begin{array}{l}\text { St George's } \\
\text { Hospital } \\
\text { Medical } \\
\text { School, } \\
\text { London }\end{array}$ & $\begin{array}{l}\text { Dr ND } \\
\text { Carter } \\
(' 87-' 90)\end{array}$ & None identified \\
\hline \multicolumn{6}{|c|}{ Genetic damage/mechanisms projects } \\
\hline $\begin{array}{l}\text { Mutations in } \\
\text { thrombotic } \\
\text { disease }\end{array}$ & $£ 154,700$ & Yes & $\begin{array}{l}\text { Thrombosis } \\
\text { Research } \\
\text { Institute, } \\
\text { London }\end{array}$ & $\begin{array}{l}\text { Dr DN } \\
\text { Cooper } \\
\text { ('92-'95) }\end{array}$ & $\begin{array}{l}\text { Four }{ }^{69,70,71,72} \\
\text { ( plus one } \\
\text { acknowledging } \\
\text { "British- } \\
\text { American } \\
\text { PLC",73) }\end{array}$ \\
\hline $\begin{array}{l}\text { p53 and cell } \\
\text { cycle }\end{array}$ & $£ 141,700$ & Yes & $\begin{array}{l}\text { Marie } \\
\text { Curie } \\
\text { Research } \\
\text { Institute } \\
\end{array}$ & $\begin{array}{l}\text { Dr G Currie } \\
\text { ('90-'93) }\end{array}$ & None identified \\
\hline $\begin{array}{l}\text { Oxidative } \\
\text { DNA } \\
\text { damage }\end{array}$ & $£ 145,000$ & Yes & $\begin{array}{l}\text { Copen- } \\
\text { hagen } \\
\text { University, } \\
\text { Denmark }\end{array}$ & $\begin{array}{l}\text { Prof H } \\
\text { Poulsen } \\
\text { ('94-'96) }\end{array}$ & Four $^{74,75,76,77}$ \\
\hline
\end{tabular}




\begin{tabular}{|l|l|l|l|l|l|}
\hline $\begin{array}{l}\text { DNA } \\
\text { adducts }\end{array}$ & $£ 123,600$ & No & $\begin{array}{l}\text { Roskilde } \\
\text { University, } \\
\text { Denmark }\end{array}$ & $\begin{array}{l}\text { Prof J } \\
\text { Clausen } \\
\text { ('90-'93) }\end{array}$ & One $^{78}$ \\
\hline $\begin{array}{l}\text { p53 in head } \\
\text { and neck } \\
\text { cancer }\end{array}$ & $£ 80,200$ & No & $\begin{array}{l}\text { University } \\
\text { of } \\
\text { Liverpool }\end{array}$ & $\begin{array}{l}\text { Prof PM } \\
\text { Stell } \\
\text { ('91) and } \\
\text { Dr JK Field } \\
\text { ('92-'93) }\end{array}$ & None identified. \\
\hline $\begin{array}{l}\text { DNA } \\
\text { adducts and } \\
\begin{array}{l}\text { free radical } \\
\text { damage }\end{array}\end{array}$ & $£ 60,000$ & Yes & $\begin{array}{l}\text { MRC } \\
\text { Toxicology } \\
\text { Unit, } \\
\text { Leicester }\end{array}$ & $\begin{array}{l}\text { Dr P Farmer } \\
\text { ('93-'96) }\end{array}$ & None identified \\
\hline $\begin{array}{l}\text { Review of } \\
\text { cytokines }\end{array}$ & $£ 11,000$ & No & Not known & Nelson ('95) & Not known \\
\hline
\end{tabular}

\section{Journal publications}

Table 2 also shows the publications acknowledging BAT funding relating to each project.

The largest number of journal papers resulted from the project led initially by Professor Jeffrey Idle at the University of Newcastle upon Tyne, UK. Of the 16 papers by his research team listed in Table 2, six also acknowledge CTR funding and two acknowledge both the CTR and the Smokeless Tobacco Research Council (STRC, another tobacco-industry-funded body). Six additional papers ${ }^{79,80,81,82,83,84}$ acknowledge support from the CTR and another three acknowledge the STRC. ${ }^{85,86,87}$ Fourteen of these 25 tobacco-funded papers (12 with Idle's name on) were published in Pharmacogenetics. Idle was editor-in-chief of Pharmacogenetics from 1991 to October $1998,{ }^{88,89}$ a journal which he founded whilst receiving BAT funding.

For most of the projects we were unable to identify any journal papers acknowledging BAT funding.

\section{Projects}

\section{Genetic susceptibility to lung cancer}

Research on genetic susceptibility to lung cancer received the most funding, confirming the tobacco industry's continued interest in this area of research. Jeffrey Idle's project was also the only project simultaneously funded by the CTR. ${ }^{90}$ Chronologies for the projects involving Idle, Daly, Rothschild and Springall are provided in the supplementary material S1 and S2.

Idle informed the CTR in $1986^{91}$ that his 1984 Nature paper on role of the CYP2D6 gene in metabolism of the drug debrisoquine and its link to risk of lung cancer "may herald a long-overdue change in the practice of epidemiology" and that he had established collaboration with the US National Institutes of Health (NIH) to pursue "the host factors which determine individual lung cancer risk". He joined the CTR's Scientific Advisory Board (SAB) ${ }^{92}$ in July 1986. Statements to the press by the NIH in 1987, endorsing Idle's results and suggesting that genetic testing would allow 
smoking cessation to be targeted at a minority of smokers, were regarded as "favorable publicity" by the industry. ${ }^{93,94}$ This led to a presentation by Idle to the CTR Board (which included representatives of six tobacco companies, two legal firms and the CTR's PR company) in December $1987 .{ }^{95,96}$

Within a month, CTR and BAT public relations advisors became involved in helping him establish a "Laboratory of Cancer Pharmacogenetics" in the UK. ${ }^{97}$ The Pharmacogenetics Unit in the University of Newcastle Medical School, was "greatly expanded and revamped" to create a Chair for Idle. BAT's chairman, Patrick Sheehy, was kept informed of progress. ${ }^{98,99,100,101}$ The university received a five-year "research agreement" from BAT on Idle's move there in September 1988. ${ }^{102}$ In 1992, $50 \%$ of the project funding for "this and related research" at the unit was from the tobacco industry, ${ }^{103}$ which spent US\$1.5 million on research projects there from 1989 to 1996 (Table 3). The unit also received substantive funding from the North of England Cancer Research Campaign, the UK Medical Research Council (MRC) and the pharmaceutical company Bayer.

Table 3: Tobacco-funded projects in the Pharmacogenetics Unit, University of Newcastle Upon Tyne

\begin{tabular}{|l|l|l|l|l|}
\hline Dates & Project & Funds & Funder & Researchers \\
\hline $1989-1990$ & $\begin{array}{l}\text { A case/control study of } \\
\text { breast and lung cancer with } \\
\text { the addendum of the } \\
\text { debrisoquine study* }\end{array}$ & US\$77,700 & CTR & JR Idle \\
\hline $1989-1997$ & $\begin{array}{l}\text { Cytochrome P450 } \\
\text { polymorphisms }\end{array}$ & $\begin{array}{l}\text { US\$772,000 } \\
107 \\
\left(£ 530,880^{\dagger}\right)\end{array}$ & BAT & $\begin{array}{l}\text { JR Idle, } \\
\text { AK Daly }\end{array}$ \\
\hline $1991-1994$ & $\begin{array}{l}\text { Pharmacogenetic } \\
\text { epidemiology of lung } \\
\text { cancer }\end{array}$ & US\$296,500 & CTR & $\begin{array}{l}\text { JR Idle, } \\
\text { AK Daly }\end{array}$ \\
\hline $1991-1994$ & $\begin{array}{l}\text { Pharmacogenetics of } \\
\text { nicotine metabolism }\end{array}$ & US\$318,700 & STRC & $\begin{array}{l}\text { JR Idle, } \\
\text { S Cholerton }\end{array}$ \\
\hline
\end{tabular}

* Idle's collaboration with Professor Henry Lynch (Omaha, USA). ${ }^{110}$ The first payment of US\$47,000 was made prior to Idle's move to Newcastle and is not included in the table. $\uparrow$ Source: SRG budget documents. Two 3-year projects were funded.

$\$$ The Smokeless Tobacco Research Council (STRC), another tobacco-industry-funded body. ${ }^{111}$

BAT's commitment to fund Idle's project was made on 7 April $1988,{ }^{112}$ some days before his project was formally approved by the $\mathrm{SRG}^{113}$ and several months before his research proposal ${ }^{114}$ received an extremely critical review from Feinstein: a review which questioned his understanding of statistics. ${ }^{115}$ The funding decision was influenced by a meeting with the leading molecular biologist (now a Nobel Laureate) Dr Sydney Brenner, then director of the MRC's Laboratory of Molecular Biology (LMB) in Cambridge. BAT report that Brenner:

"went so far as to recommend the industry should carry out screening, if appropriate, for those individuals carrying genetic markers for diseases such as lung cancer". ${ }^{116}$ 
The tobacco industry's main aim in funding projects like Idle's was to identify a "genetically susceptible" minority of smokers so that smoking cessation efforts could be targeted at them and "the rest of the population can be allowed to puff away contentedly and without serious risk". ${ }^{117}$

BAT met Brenner on 30 March 1988. By the end of April he was a founding member of the Human Genome Organisation (HUGO), an organization that he is credited with first proposing. ${ }^{118}$ At the time, Brenner was also a member of the Council of the MRC. ${ }^{119}$ According to the Wellcome Trust, it was Brenner who gained the personal support of the then prime minister, Margaret Thatcher, after Brenner and Sir Walter Bodmer (a former student of Ronald Fisher) initially had difficulty persuading influential bodies in the UK to 'think big' about the genome. ${ }^{120}$ In 1986, Brenner had been told that any human genome mapping had to be undertaken within the MRC's existing budget, but after gaining the prime minister's support, the MRC was awarded an extra $£ 11$ million over three years, agreed in February 1989 and paid from the start of the $1989 / 90$ financial year. ${ }^{121}$ There is no suggestion that Brenner was receiving funding from the tobacco industry in March 1988. However, BAT's memo of the meeting notes that he "seemed quite willing to meet with BAT again on a specific subject".

A conference abstract by NIH researchers, sent "in confidence" by Idle to BAT, also appears to have influenced BAT's decision to fund his research. ${ }^{122,123}$ The CTR's response to a 1989 New York Times article advocating genetic screening of smokers ${ }^{124}$ was ecstatic, describing the NIH's statements as "vindication" of its research strategy, ${ }^{125}$ and interest from the NIH prompted the CTR to invite Idle to resubmit one of his research proposals ${ }^{126}$ and to make an extra payment to him. ${ }^{127,128}$

Beginning in 1988, a series of studies failed to confirm Idle's hypothesis of a link between CYP2D6 polymorphisms and lung cancer. ${ }^{129,130,131,132,133}$ CTR-funded studies in Norway and Los Angeles also failed to confirm the association and both were ultimately published (in 1994 and in 1997). However, prior to the publication of the Los Angeles results, Idle co-authored a series of reviews ${ }^{134,135,136,137,138}$ and conference papers ${ }^{139}$ implying that genetic susceptibility to lung cancer had been firmly established.

One review was published in Pharmacogenetics when Idle was already aware that the preliminary results from Norway did not confirm the proposed association ${ }^{140}$. A response (also in Pharmacogenetics, but not published until two years later) concludes that the review is "factually misleading and gives an incorrect impression of ...the current conclusions which can be drawn from the literature". ${ }^{141}$ Genetic variations in CYP2D6 are now thought to play little or no role in lung cancer. ${ }^{142,143,144,145}$

Henry Rothschild (University of Louisiana) was funded by the CTR from $1977 .{ }^{146,147}$ In 1982, Rothschild gave evidence on behalf of the tobacco industry to the Waxman Hearings, which were considering proposals for new stronger warning labels on US cigarette packs. The industry argued that: "Science...would be frozen in its tracks if 
Congress, through such legislation, tries to settle unresolved medical and scientific controversies." Rothschild gave evidence that genetics may determine who gets lung cancer. ${ }^{148}$ The following month, on the advice of tobacco-industry lawyers, ${ }^{149}$ he was awarded a new 'Special Project' grant by the CTR to study genetic factors in lung cancer in Louisiana families. ${ }^{150}$ Rothschild received US\$160,700 in total from the CTR for research on genetic factors in lung cancer. ${ }^{151,152,153,154} \mathrm{He}$ co-authored three papers during this time that claim to support the concept of genetic susceptibility to lung cancer (none acknowledge tobacco industry funding). ${ }^{155,156,157,158}$

In 1990 the Journal of the National Cancer Institute (JNCI) published two articles on genetic susceptibility to lung cancer - one by NCI researchers ${ }^{159}$ and one by Sellers et al., ${ }^{160}$ on which Rothschild is a co-author and CTR funding is acknowledged. BAT describe the NCI researchers as "close to" Idle's group. ${ }^{161}$ The papers gained extensive press coverage, ${ }^{162,163,164}$ some of which led to scientific criticism of the researchers for implying that genetics rather than smoking determines whether lung cancer develops. ${ }^{165}$

Following the publicity surrounding the Sellers et al. (1990) paper, this research group published two further related papers which acknowledge CTR funding ${ }^{166,167}$ and three which do not. ${ }^{168,169,170}$ Springall's BAT-funded project sought to confirm the Sellers et al. findings, using the Louisiana data set (purchased by BAT for $£ 25,000^{171}$ ). In 1993, Springall reported that he had successfully reproduced the segregation analysis ${ }^{172}$, following initial difficulties. ${ }^{173}$

Rothschild's colleague J.E. Bailey-Wilson presented his team's proposal for a pilot study of lung cancer probands with at least two affected relatives to BAT in October $1993^{174}$. The SRG minutes record that if the pilot study fails to identify any genetic markers, the team hopes to go on to a global screen of the genome, funded by the NIH. BAT subsequently agreed to fund Rothschild's genetic-linkage project "pending funding by the NIH". ${ }^{175}$ We have been unable to identify any papers by Rothschild acknowledging BAT funding. Two NIH-funded papers by other authors also conclude that a major gene explains familial aggregation of lung cancer: both rely solely on Rothschild's Louisiana data set. ${ }^{176,177}$ In 2000, Rothschild was awarded three grants by the NIH, totalling more than US $\$ 660,000$, to continue his research. ${ }^{178}$

In 2004, Bailey-Wilson et al. published a paper identifying a major lung cancer susceptibility locus in 771 families with three or more first-degree relatives affected with lung cancer. ${ }^{179}$ Press reports again claimed that the study paved the way for a genetic screening test to identify susceptible smokers. ${ }^{180,181,182}$ The paper appears to report the next step in the pilot project presented to BAT by Bailey-Wilson in 1993, and subsequently funded via a grant to Rothschild "pending funding by the NIH", as described above. Rothschild is a co-author on the paper. A subsequent paper, on which Bailey-Wilson and Rothschild are co-authors, investigates a different locus, again with funding from the NIH as part of the Genetic Epidemiology of Lung Cancer Consortium. ${ }^{183}$ The paper claims that evidence of a genetic basis for susceptibility to lung cancer has been demonstrated through genome-wide association studies (citing three new studies ${ }^{184,185,186}$ ) and via the segregation analyses previously reported by 
the group in Sellers et al. (1990) and subsequent papers. It reports a further genomewide association study among individuals with a family history of lung cancer.

\section{Genetic damage}

BAT supported a basic research programme on the p53 tumor suppressor gene at the Marie Curie Research Institute from 1987, led by its former director, Graham Currie. Currie's colleague John Jenkins also worked on the project, which received $£ 240,000$ over eight years to the end of 1993. ${ }^{187}$ Bitton et al. (2005) document how this relationship gave BAT an early insight into research on $\mathrm{p} 53$, which they felt could lead to either benefits or problems for the industry.

One BAT-funded researcher, John Field, believed that research on p53 mutations had added weight to the link between smoking and lung cancer. ${ }^{188}$ The original lead researcher on his project, Philip Stell, had given evidence on the tobacco industry's behalf in a smoking damages case in Finland in $1991^{189}$ but Field took on the project when Stell retired. In March 1994, BAT decided that further funding for Field's project was "low priority" 190 and the SRG then noted: "Applications from other p53 researchers will be sought." 191

In contrast, a discussion forum by Krawczek and Cooper, ${ }^{192}$ published in Mutagenesis in 1998, uses an earlier paper, Krawczak et al. $(1995)^{193}$, as the basis of a rebuttal of new evidence for a unique genetic fingerprint for tobacco smoke in p53 mutations in lung cancer cells. James Parry, editor in chief of Mutagenesis from $1986^{194}$ until November $2001^{195}$ was a BAT consultant in $1993^{196,197}$ and in 1998 was receiving project funding from Philip Morris. ${ }^{198}$ Bitton et al. (2005) note that no funding source or competing interests were reported in the discussion forum, but find no evidence that either Cooper or Krawczak received tobacco funding for this research. However, we have identified additional evidence that the earlier Krawczak et. al.(1995) paper, on which the forum was based, was BAT-funded:

- Two of the authors (Cooper and Kakkar) received research funding from BAT (Kakkar from 1987-1992, for a project on arterial damage which we did not classify as 'genetic research' for the purposes of this investigation, see supplementary material S1; Cooper from 1992, as shown in Table 2). ${ }^{199}$

- A BAT note of a visit to Cooper in June $1992^{200}$ and the minutes of two SRG meetings in $1993^{201,202}$ outline the proposed comparison reported in the paper.

- A BAT note of a visit to Krawczak in Germany in September 1993 records that he is working with Cooper on a paper making this comparison and what they have found. ${ }^{203}$

- A BAT memo from July 1994 refers to an enclosed "paper in press" from Cooper and cites part of the abstract. ${ }^{204}$

- A BAT memo from March 1995 outlines new evidence linking mutations in the p53 gene to tobacco smoke and references Krawczak et al. (1995) as the basis of BAT's rebuttal of the evidence. ${ }^{205}$

Bitton et al. (2005) document how Parry again published a response in Mutagenesis when further evidence that smoking causes specific mutations to the p53 gene was 
published, this time from an author based at a private institute sponsored by the German Association of Cigarette Manufacturers. When one of the authors of the original paper discovered Parry's tobacco industry links, the journal's publishers introduced a conflict of interest policy. Parry, who did not sign up to the arrangement, then left his role as Editor-in-Chief, and transferred to a non-executive role on the editorial board. ${ }^{206}$

Poulsen, Clausen and Farmer's projects investigated different types of DNA damage (oxidative damage and DNA adducts) in smokers and non-smokers. Poulsen's research included attempts to try to reduce oxidative DNA damage in smokers by giving them dietary supplements. ${ }^{207}$ The efficacy of this approach is questionable ${ }^{208}$ and beta-carotene supplements are now believed to increase risk of death in smokers. $^{209,210,211}$

\section{Other issues}

We did not analyse the documents we collected which relate to environmental tobacco smoke (ETS). However, we found one example where genetic research was used to seek to undermine evidence of children's exposure to ETS. In 1990 BAT's consultant Feinstein published a commentary by Idle in the Journal of Clinical Epidemiology criticising work on ETS by Jarvis et al. ${ }^{212,213}$ In the article, which did not declare tobacco funding, Idle argued that genetic variations in cotinine metabolism make cotinine tests an unreliable measure of tobacco smoke exposure. Philip Morris had commissioned an outline of a review of cotinine from Idle in March 1989. ${ }^{214,215}$ A faxed copy of his paper is in Philip Morris' files, dated 4 July $1989,{ }^{216}$ a week before the Journal of Clinical Epidemiology recorded receiving it. Idle copied his acceptance letter from Feinstein to BAT, saying:

"Dear Ray, with the compliments of Professor Jeffrey Idle, Cotinine editorial now in press! (no changes asked for!) Regards Jeff."

\section{Discussion}

Our research has some limitations. We focused on the academic research funded by a single company (BAT) and restricted our analysis to projects involving human genetics. Our searches and the documents themselves may not be comprehensive, nor are recent documents generally available. However, our approach also has some strengths. Firstly, the SRG budgets we obtained are complete for the period 19901995, enabling us to assess the relative importance of the different projects at this time. Secondly, searching the CTR and Philip Morris collections and PubMed for the names of the BAT consultants and researchers allowed us to build an in-depth picture of the history of the projects and related journal publications. Searching by name is one of the most effective strategies for identifying tobacco industry documents.

The majority of SRG-funding in the period 1990-1995 was spent on human genetic research. The main area of research was genetic predisposition to lung cancer. Research was also used to counter potential threats to business (particularly the link between p53 mutation patterns and tobacco smoke) and to study ineffective alternatives to tobacco control (such as giving smokers vitamin supplements). 
The tobacco industry selected research projects to suit its own strategic interests. Lawyers and public relations firms both played a role in influencing its research agenda. The industry's influence did not lie in scientific fraud or suppression of results, but in providing significant support for those researchers who adopted its perspective. Idle, for example, remained sceptical that smoking causes lung cancer until at least 1999, when he endorsed Fisher's theory in a letter to the Lancet. ${ }^{219}$ Vijay Kakkar, director of the Thrombosis Research Institute in London, where Cooper was based, reportedly informed the SRG in June 1992 that his hypothesis was that the most important risk factor for heart disease is not smoking, but levels of mercury in water. In addition, journal editors who were also receiving industry funding as consultants 'placed' editorials from seemingly independent scientists to support the industry's position in matters of scientific controversy.

The tobacco industry's funding decisions played an important role in shaping the genetic research agenda, contributing to a scientific "race to find the gene or genes which predispose to lung cancer". ${ }^{220}$ Idle, in particular, boasted of his connections with the NIH and was a member of the Lung Cancer Task Force at the US National Cancer Institute (NCI) from 1984, when the NIH began to increase massively its spending on cancer genetics research, creating the "scientific bandwagon" described by Fujimura (1988).

Our research suggests that a coincidence of interests between advocates of molecular genetic research and the tobacco industry helped to drive this scientific bandwagon, as demonstrated by the timing of the meeting between BAT and Sydney Brenner. This meeting led to the establishment of Idle's pharmacogenetics unit in 1988 - with funding from the tobacco industry, Bayer and the MRC - at a time when Brenner was anxious to convince the Thatcher government of the industrial applicability of human genome mapping. Brenner was not receiving funding from BAT at the time of the reported meeting. However, some years later, in 1996, the journal Science reported that a new 'Molecular Sciences Institute', based at La Jolla in the USA, for which Brenner had been recruited as director, was to receive a grant of $\$ 15$ million a year for 15 years from Philip Morris (a plan which appears to have been first discussed with Brenner in $1994^{221}$ ). ${ }^{222}$ Following this exposé, Brenner and Philip Morris terminated their research funding agreement for the institute. ${ }^{223}$

The benefits to the tobacco industry of the promotion of gene screening for smokers are clear: it regarded the public endorsement of genetic screening by the NCI in press stories in 1987 and 1990 as "favorable publicity" and "vindication" of the research strategy that it had followed since the 1950s. Media stories about genetics are likely to exert a powerful public influence ${ }^{224}$ and self-exempting beliefs, such as believing in genetic causes for lung cancer, are one strategy used by smokers to avoid facing the difficulties involved in quitting smoking. ${ }^{225}$ Combined with the Thatcher government's reluctance to strengthen tobacco control measures, it seems likely that the promotion of this 'scientific solution' to the problem of lung cancer both benefited the industry and harmed public health. 
The main advantages for the scientific proponents of molecular genetics were: the opportunity to claim that their research could have a major impact on the incidence of cancer, rather than being restricted to studying biological mechanisms and rare familial diseases; and the chance to gain support from industry. This was particularly important as they sought to win public and political support (including financing) for human genome mapping in both the UK and the USA (where the Human Genome Initiative was launched in 1991).

The difficulties in replicating genetic association studies are now well known ${ }^{226}$ and we found no evidence of scientific fraud. However, we did find evidence of interpretative bias (particularly "rescue bias"227) as contradictory evidence was discounted or ignored. Early studies tended to over-estimate genetic risk and in some cases expression of the relevant enzyme in the lung is very low ${ }^{228,229}$ or nonexistent, ${ }^{230}$ making a role in lung cancer unlikely. In the case of Idle's research, this situation was exacerbated by 'self-publication' in a journal which he edited and founded, and his poor grasp of statistical method.

Rothschild's group also drew erroneous conclusions, probably as a result of sloppy science, rather than an intention to mislead. Familial aggregation of disease does not necessarily imply a genetic component ${ }^{231}$ and segregation analysis is sensitive to the assumptions made, which may give rise to spurious evidence of Mendelian inheritance. $^{232}$

In general, researchers seem to have genuinely believed that they could benefit their own careers and at the same time find a 'scientific solution' to the lung cancer problem that would also benefit the industry. Thus Proctor (1995) reports that molecular epidemiologists were surprised when a 1994 NIH twin study found "little if any effect of inherited predisposition on development of lung cancer". Earlier twin studies had also failed to identify an inherited component, but, in the excitement of the race to find the genes for lung cancer, it had simply been presumed that these studies were not large enough. Small differences in genetic risk could still exist, as could rare cases of familial lung cancer, but this does not mean that genetic screening can be used to 'predict and prevent' lung cancer in the general population. ${ }^{233,24}$

The idea that genetic screening would be of benefit to smokers nevertheless persists in the scientific literature and in the media. In 2003, press reports based on a new scientific paper ${ }^{234,235}$ claimed that a genetic test would be developed within three to four years to "show which smokers face lung cancer death". 236,237,238,239,240 Searches we conducted using the CTR website revealed that the study's corresponding author and press spokesman, Professor Zvi Livneh, had a history of funding from the tobacco industry (receiving \$519,069 in funding from the CTR from July 1985 to June $1992)^{241,242,243,244,245,246,247}$.

Although genetic population screening has not (yet) been implemented, the policy implications of our findings are significant. In 1995, Idle co-authored a paper in Pharmacogenetics which advocates genetic screening of whole populations, with data stored on individual patient SMART cards, and expert computer systems on every 
doctor's desk. ${ }^{248}$ This idea, and claims that this approach would be of benefit to public health, subsequently became widely advocated: most famously in a May 1999 lecture given by the leader of the Human Genome Project at the NIH, Francis Collins, ${ }^{249}$ by the UK Prime Minister Tony Blair in 2002, ${ }^{250}$, and in a 2003 UK Government White Paper which set out a vision for genetics in the National Health Service. ${ }^{251}$ Yet, 20 years after BAT helped to establish the first university pharmacogenetics unit, there is still limited potential for the genetic variants thus far identified (singly or in combination) to provide clinically useful prediction of either common diseases (including cancer) or adverse drug reactions in the general population. ${ }^{252,253,254,255,256}$

Our findings highlight the need for policy-makers, academic institutions and charities to take greater care to avoid conflicts of interest and to set health research priorities that are in the public interest, not in the interests of tobacco companies. More broadly, other industries - including the food and pharmaceutical industries - may have vested interests in promoting human genome screening, as may governments who are interested in expanding DNA databases for surveillance purposes. ${ }^{257,258}$

Our research suggests that the main danger lies in failure to scrutinise the exaggerated promises that scientists make to both policy makers and the media in order to secure funding, rather than in scientific fraud. ${ }^{259,260,261}$ As Rose (1994) describes, fear of cancer became a powerful motivator for science funding for the Human Genome Project, but this also involved a political commitment to looking for causes within the human body (to the supposedly determining genetic code), rather than outside, at the causes to be found within everyday life and people's environments. ${ }^{262}$ The opportunity costs may be significant. Nightingale and Martin (2004) state:

"Unrealistic expectations are dangerous as they lead to poor investment decisions, misplaced hope, and distorted priorities, and can distract us from acting on the knowledge we already have about the prevention of illness and disease". ${ }^{263}$

We conclude that the tobacco industry has played a significant role in shaping research agendas: in particular, by promoting the idea that individual genome screening would be of benefit to public health. Commercial vested interests can create and drive scientific bandwagons by bankrolling research in scientific institutions, and placing reviews and articles in scientific journals, thus attracting public funding and building political support. This may drain considerable resources from more valuable approaches, wasting time and money and ultimately costing lives.

Our research suggests that transparency, whilst undoubtedly important, is not enough to ensure that science is conducted in the public interest. Many of Idle's papers, for example, did declare his funding sources, apparently without limiting the tobacco industry's influence on the research agenda or reporting of that research, both in scientific journals and in the wider press. It seems likely that subsequent decisions by many funders, including the MRC, NIH and most major charities, to cease co-funding tobacco industry research has been more effective. From 1988-1994 only one UK 
medical school did not accept tobacco funding, ${ }^{264}$ and charities that jointly funded the research described above included: the Wellcome Trust ${ }^{53,59}$ the North of England Cancer Research Campaign and the North of England Childrens' Cancer Research Campaign, the American Cancer Society, the Norwegian Cancer Society and Stop Cancer (California) ${ }^{80,81,82}$ However, the decision to cease co-funding has not prevented other industries from adopting similar approaches. ${ }^{265}$

Our findings highlight how research funding mechanisms established by the Thatcher and Reagan governments allowed vested interests to set research priorities in universities and public institutions and to encourage widespread publication, endorsement and reporting of spurious scientific findings. We recommend that, in addition to transparency, more democratic decisions about research funding priorities are required. This should include greater public accountability and scrutiny of research investment decisions, and active steps to prevent political 'entrapment' in research agendas based on false assumptions and misleading claims.

\section{Acknowledgements}

The initial research for this project was funded by Cancer Research UK. Ben Ayliffe, then a researcher at Action on Smoking and Health (ASH), identified all the relevant BAT documents in the Guildford depository, under the supervision of ASH's former Director Clive Bates. The author conducted all subsequent searches. Thanks are due to Jane Varley for helping to catalogue the BAT documents. A more recent grant from the Joseph Rowntree Charitable Trust has enabled the author to complete this work.

\footnotetext{
${ }^{1}$ GeneWatch UK, 60 Lightwood Rd, SK17 7BB, UK. helen.wallace@genewatch.org

${ }^{2}$ R. Peto. Smoking and death: the past 40 years and the next 40. Br Med J 1994; 309: 937-939.

${ }^{3}$ M.J. Jarvis. Epidemiology of cigarette smoking and cessation. J Clin Psychiatry Monograph 2003; 18(1): 6-11.

${ }^{4}$ S.A. Glanz., D.E. Barnes., L. Bero., P. Hanauer and J. Slade. Looking through a keyhole at the tobacco industry: the Brown and Williamson documents. J Am Med Assoc 1995; 274: 219-224.

${ }^{5}$ P. Hanauer, J. Slade, D.E. Barnes, L. Bero and S.A. Glanz. Lawyer control of internal scientific research to protect against products liability lawsuits. J Am Med Assoc 1995; 274: 234-240.

${ }^{6}$ D.E. Barnes, P. Hanauer, J. Slade, L.A. Bero and S.A. Glanz. Environmental Tobacco Smoke: the Brown and Williamson documents. J Am Med Assoc 1995; 274: 248-253.

${ }^{7} \mathrm{M}-\mathrm{K}$. Hong and L.A. Bero. How the tobacco industry responded to an influential study of the health effects of secondhand smoke. Br Med J 2002; 325: 1413-1416.

${ }^{8}$ Action on Smoking and Health. Project Whitecoat - how Philip Morris bought up scientists and

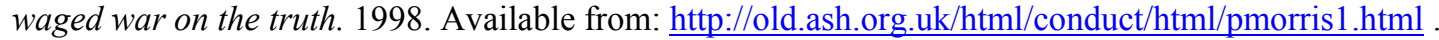
Accessed: 31 October, 2008.

${ }^{9}$ J. Slade, L.A. Bero, P. Hanauer, D.E. Barnes and S.A. Glanz. Nicotine and addiction: The Brown and Williamson documents. J Am Med Assoc 1995; 274: 225-233.

${ }^{10}$ A bibliography of publications based on research and analysis of tobacco industry documents is available on: http://www.library.ucsf.edu/tobacco/docsbiblio.html . Accessed: 31 October, 2008.

${ }^{11}$ J.H. Fujimura. The molecular biological bandwagon in cancer research: where social worlds meet Social Problems 1988; 35(3): 261-283.

${ }^{12}$ J.F. Glenn. [Testimony of James F Glenn, M.D., President, Chairman and Chief Executive Officer of the Council for Tobacco Research - USA, Inc. before the Subcommittee on Health and the Environment of the Committee on Energy and Commerce, US House of Representatives]. 25 May,
} 
1994. Philip Morris. Bates No. 2022881049/1061. Available from: http://tobaccodocuments.org/pm/2022881049-1061.html . Accessed: 31 October, 2008.

${ }^{13}$ R.N. Proctor. 1995. Cancer wars: How politics shapes what we do and don't know about cancer. New York: Basic Books.

${ }^{14}$ R.A. Fisher. Dangers of cigarette-smoking. Br Med J 1957; 2: 297-298.

${ }^{15}$ R.A. Fisher. Lung cancer and cigarettes? Nature 1958; 182: 108.

${ }^{16}$ Reuters. Genetic basis suggested. The New York Times July 13, 1958. Bates No. 10030982/0982.

Council for Tobacco Research. Available from: http://legacy.library.ucsf.edu/tid/her2aa00 . Accessed: 31 October, 2008.

${ }^{17}$ A.E. Reif. Effect of cigarette smoking on susceptibility to lung cancer. Oncology 1981; 38: 76-85.

${ }^{18}$ G. Kellermann, C.R.Shaw and M. Luyten-Kellerman. Aryl Hydrocarbon Hydroxylase inducibility and bronchogeneic carcinoma. New Engl J Med 1973; 289: 934-937.

${ }^{19}$ L.K. Altman. Blood tests point to smokers with genetic tendency to cancer. The New York Times November 19, 1973. Council for Tobacco Research. Bates No. ZN10221/0221. Available on: http://legacy.library.ucsf.edu/tid/xxw2aa00 .Accessed: 31 October, 2008.

${ }^{20}$ C.R. Shaw. [Carcinogenesis Application For Research Grant Hydrocarbon Metabolizing Enzymes And Lung Cancer]. 17 July, 1973. Council for Tobacco Research. Bates No. 50101921/1936. Available from: http://legacy.library.ucsf.edu/tid/dxl46d00 . Accessed: 31 October, 2008.

${ }^{21}$ R.C. Hockett. [Letter to Charles Shaw]. 20 November, 1973. Bates No. 50101897/1898. Available from: http://legacy.library.ucsf.edu/tid/zxl46d00 . Accessed: 31 October, 2008.

${ }^{22}$ P. Lichtenstein, N.V. Holm, P.K. Verkasalo, A. Iliadou, J. Kaprio, M. Koskenvuo, E. Pukkala, A. Skytthe and K. Hemminki. Environmental and heritable factors in the causation of cancer - analyses of cohorts of twins from Sweden, Denmark, and Finland. N Engl J Med 2000; 343(2): 78-85.

${ }^{23}$ M.M. Braun, N.E. Caporaso, W.F. Page and R.N. Hoover. A cohort study of twins and cancer. Cancer Epidemiol Biomarkers Prev 1995; 4(5):469-73.

${ }^{24}$ H.M. Wallace. A model of gene-gene and gene-environment interactions and its implications for targeting environmental interventions by genotype. T. Biol. Med. Model 2006: 3 (35). doi:10.1186/1742-4682-3-35. http://www.tbiomed.com/content/3/1/35 .

${ }^{25}$ N.J. Wald and A.K. Hackshaw. Cigarette smoking: an epidemiological overview. Br Med Bull 1996; 52 (1); 3-11.

${ }^{26}$ M. Ezzati and A.D. Lopez. Estimates of global mortality attributable to smoking in 2000. Lancet $2003 ; 362 ; 847-852$.

${ }^{27}$ T.W. Marcy, M. Stefanek and K.M. Thompson. Genetic testing for lung cancer risk: If physicians can do it, should they? J Gen Intern Med 2002; 17: 946-951.

${ }^{28}$ W. Hall, P. Madden and M. Lynskey. The genetics of tobacco use: Methods, findings and policy implications. Tob Con 2002; 11: 119-124.

${ }^{29}$ M. Johnson. [Letter to David Greenberg (Vice President, Philip Morris Corporate Affairs Europe)]. 25 September, 1996. Bates No. 2060546551/6552. Philip Morris. Available from: http://tobaccodocuments.org/pm/2060546551-6552.html. Accessed: 31 October, 2008.

${ }^{30}$ British American Tobacco. The tobacco industry and the health risks of smoking (TB28).

Memorandum to the House of Commons Select Committee on Health; 13 January, 2000. In: The tobacco industry and the health risks of smoking, Volume II: Minutes of Evidence and Appendices. London; HMSO; 2000. HC 27-II.

${ }^{31}$ I. Chiba, T. Takahashi, M.M. Nau, D. D’Amico, D.T. Curiel, T. Mitsudomi, D.L. Buchhagen, D. Carbone, S. Piantadosi, H. Koga et al. Mutations in the P53 Gene Are Frequent In Primary, Resected Non-Small Cell Lung Cancer. Oncogene 1990; 5(10): 1603-1610.

${ }^{32}$ M. Hollstein, D. Sidransky, B. Vogelstein and C.C. Harris. P53 Mutations in Human Cancers. Science 1991; 253: 49-53.

${ }^{33}$ M.F. Denissenko, A. Pao, M. Tang and G.P. Pfeiffer. Preferrential formation of benzo[a]pyrene adducts at lung cancer mutational hotspots in P53. Science 1996; 274: 430-32.

${ }^{34}$ A. Bitton, M.D. Neuman, J. Barnoya and S.A. Glantz. The p53 tumour suppressor gene and the tobacco industry: research, debate and conflict of interest. The Lancet 2005; 365(9458): 531-40.

${ }^{35}$ J. Collin, K. Lee and A.B. Gilmore. Unlocking the corporate documents of British American Tobacco: an invaluable global resource needs radically improved access. Lancet 2004; 363: 1746-1747. 
${ }^{36}$ R.E. Malone and E.D. Balbach. Tobacco industry documents: treasure trove or quagmire? Tob Con 2000; 9:334-338.

${ }^{37}$ M.E. Muggli, E.M. LeGresley and R.D. Hurt. Big tobacco is watching: British American Tobacco's surveillance and information concealment at the Guildford depository. Lancet 2004; 363: 1812-1819.

${ }^{38}$ Available from: http://www.ctr-usa.org/ctr/index.wmt?tab=home. Accessed: 31 October, 2008.

${ }^{39}$ Available from: http://www.pmdocs.com. Accessed: 31 October, 2008.

${ }^{40}$ Available from: http://www.ncbi.nlm.nih.gov/sites/entrez. Accessed: 31 October, 2008.

${ }^{41}$ C.J. Proctor. Memo to Mr B.D. Bramley, 2 November, 1994. Bates No. 500833956. Available from: http://legacy.library.ucsf.edu/tid/kvi10a99/pdf. Accessed: 31 October, 2008.

42 Anon (undated), Current Members of SRG Committee; Smoking and Health and the Regulatory Environment: Group Strategic Objectives; Group Smoking and Health Issues: R\&D Responsibilities and Programme; Programme Logic; SRG Projects and Budget 1992/1993. Bates No. 400501318-1322. Available from: http://old.ash.org.uk/html/conduct/pdfs/genetics/srg objs.pdf Accessed: 31 October, 2008.

${ }^{43}$ SRG (1993), Discussion Document: Smoking and Health: Future Strategies for Research. Bates No. 400501079-1091. Available from: http://old.ash.org.uk/html/conduct/pdfs/genetics/strat.pdf. Accessed: 31 October, 2008.

${ }^{44}$ BAT (undated), Standard Form - Research Grant. Bates No. 500874435-4437. Available from: http://old.ash.org.uk/html/conduct/pdfs/genetics/contract.pdf. Accessed: 31 October, 2008.

${ }^{45}$ BAT. Letter from R Thornton to James Parry, 28 January, 1992. Bates No. 500874519-4516. Available from: http://old.ash.org.uk/html/conduct/pdfs/genetics/parry ctr.pdf. Accessed 31 October, 2008.

${ }^{46}$ BAT. Memo from R.E. Thornton to B.D. Bramley, 17 May, 1993. Bates No. 400501185-1187. Available from: http://old.ash.org.uk/html/conduct/pdfs/genetics/srg_procs.pdf. Accessed: 31 October, 2008.

${ }^{47}$ R.E. Thornton. Note for the Tobacco Strategy Group, 2 December, 1993. Bates No. 5025206690672. Available from: http://old.ash.org.uk/html/conduct/pdfs/genetics/srg_93.pdf. Accessed: 31 October, 2008.

${ }^{48}$ Tobacco Institute. The Smoking Controversy: A Perspective. January, 1978. Bates No. 10026728. Available from: http://tobaccodocuments.org/ctr/HT0014025-4062.html. Accessed: 31 October, 2008.

${ }^{49}$ R. Gertenbach. Letter to Alvan Feinstein Re; Grant \#1443, 18 November, 1981. Bates No. 50157386. Available from: http://legacy.library.ucsf.edu/tid/zjh69c00. Accessed: 31 October, 2008.

${ }^{50}$ R.F. Gertenbach. Letter to Alvan Feinstein, 15 October, 1982. Bates No. SF0590090-0090. Available from: http://tobaccodocuments.org/ctr/SF0590090-0090.html. Accessed: 31 October, 2008.

${ }^{51}$ L. Bero, D.E. Barnes, P. Hanauer, J. Slade and S.A. Glanz. Lawyer control of the tobacco industry's external research program. J Am Med Assoc 1995; 274(3): 241-247.

${ }^{52}$ A.R. Tricker. Memo to the SSRC, 8 August, 1998. Bates No. 2063595219. Available from: http://tobaccodocuments.org/pm/2063595219.html. Accessed: 31 October, 2008.

${ }^{53}$ A.K. Daly. M. Armstrong, S.C. Monkman, M.E. Idle and J.R. Idle. Genetic and metabolic criteria for the assignment of debrisoquine 4-hydroxylation (Cytochrome P4502D6) phenotypes.

Pharmacogenetics 1991; 1: 33-41.

${ }^{54}$ M. Armstrong, A.K. Daly, S. Cholerton, D.N. Bateman and J.R. Idle. Mutant debrisoquine hydroxylation genes in Parkinson's Disease. Lancet 1992; 339: 1017-1018.

${ }_{55}^{5}$ J.R. Idle, M. Armstrong, A.V. Boddy, C. Boustead, S. Cholerton, J. Cooper, A.K. Daly, J. Ellis, W. Gregory, H. Hadidi, C. Höfer, J. Holt, J. Leathart, N. McCraken, S.C. Monkman, J.E. Painter, H. Taber, D. Walker, and M. Yule. The pharmacogenetics of chemical carcinogenesis. Pharmacogenetics 1992; 2: 246-258.

${ }^{56}$ A.K. Daly, S. Cholerton, W. Gregory and J.R. Idle. Metabolic polymorphisms. Pharmac Ther 1993; 57: 129-160.

${ }^{57}$ M. Armstrong, J.R. Idle and A.K. Daly. A polymorphic CfoI site in exon 6 of the human cytochrome P450 CYP2D6 gene detected by the polymerase chain reaction. Hum Genet 1993; 91:616-617.

${ }^{58}$ A.K. Daly, D.J. Thomas, J. Cooper, W.R. Pearson, D.E. Neal and J.R. Idle. Homozygous deletion of gene for glutathione S-transferase M1 in bladder cancer. Br Med J 1993; 307(6902): 481-482.

${ }_{59}$ J.R. Idle and A.K. Daly. New opportunities in cancer risk evaluation using PCR-based DNA analysis for CYP2D6. Environ Health Perspect 1993; 101 Suppl 3: 117-120. 
${ }^{60}$ C. Beyeler, A.K. Daly, M. Armstrong, C. Astbury, H.A. Bird and J.R. Idle. Phenotype/genotype relationships for the cytochrome P450 enzyme CYP2D6 in rheumatoid arthritis: Influence of drug therapy and disease activity. $J$ Rheumatol 1994; 21(6): 1034-1039.

${ }^{61}$ M. Armstrong, K. Fairbrother, J.R. Idle and A.K. Daly. The cytochrome P450 CYP2D6 allelic variant CYP2D6J and related polymorphisms in a European population. Pharmacogenetics 1994; 4: 73-81.

${ }^{62}$ H.F. Hadidi, S. Cholerton, S.C. Monkman, M. Armstrong, Y.M. Irshaid, N.M. Rawashdeh, A.K. Daly and J.R. Idle. Debrisoquine 4-hydroxylation (CYP2D6) polymorphism in Jordanians. Pharmacogenetics 1994; 4(3): 159-161.

${ }^{63}$ A.K. Daly, S. Cholerton, M. Armstrong and J.R. Idle. Genotyping for polymorphisms in xenobiotic metabolism as a predictor of disease susceptibility. Environ Health Perspect 102 Suppl 9: 55-61.

${ }^{64}$ A.K. Daly, J.B.S. Leathart and S.J. London. An inactive cytochrome P450 CYP2D6 allele containing a deletion and a base substitution. Hum Genet 1995; 95: 337-341.

${ }^{65}$ V.M. Steen, O.A. Andreassen, A.K. Daly, T. Tefre, A.L. Borresen, J.R. Idle and A.K. Gulbrandsen. Detection of the poor metabolizer-associated CYP2D6(D) gene deletion allele by long-PCR technology. Pharmacogenetics 1995; 5(4): 215-223.

${ }^{66}$ A.K. Daly, K.S. Fairbrother, O.A. Andreassen, S.J. London, J.R. Idle and V.M. Steen. Characterization and PCR-based detection of two different hybrid CYP2D7P/CYP2D6 alleles associated with the poor metabolizer phenotype. Pharmacogenetics 1996; 6(4): 319-328.

${ }^{67}$ A.B. Singleton, J.H. Thomson, C.M. Morris, J.A. Court, S. Lloyd and S. Cholerton. Lack of association between the dopamine $\mathrm{D} 2$ receptor gene allele $\mathrm{DRD} 2 * \mathrm{~A} 1$ and cigarette smoking in a United Kingdom population. Pharmacogenetics 1998; 8: 125-128.

${ }^{68}$ K.S. Fairbrother, J. Grove, I. de Waziers, D.T. Steimel, C.P. Day, C.L. Crespi and A.K. Daly. Detection and characterization of novel polymorphisms in the CYP2E1 gene. Pharmacogenetics 1998; 8: 543-552.

${ }^{69}$ D.S. Millar, C.B. Grundy, P. Bignell, D.C. Mitchell, D. Corden, P. Woods, V.V. Kakkar and D.N. Cooper. A novel nonsense mutation in the Protein C (PROC) gene (Trp-29 $\rightarrow$ Term) causing recurrent venous thrombosis. Hum Genet 1993; 91: 196.

${ }^{70}$ A. Girolami, P. Simioni, B. Girolami, A. Marchiori, D.S. Millar, P. Bignell, V.V. Kakkar and D.N. Cooper. A novel dysfunctional Protein C (Protein C Padua 2) associated with a thrombotic tendency: substitution of Cys for Arg-1 results in a strongly reduced affinity for binding of $\mathrm{Ca}++$. Br J Haematol 1993; 85: 521-527.

${ }^{71}$ D.S. Millar, C.B. Grundy, P. Bignell, E.H. Moffat, R. Martin, V.V. Kakkar and D,N. Cooper. A Gla domain mutation (Arg 15 $\rightarrow$ Trp) in the Protein C (PROC) gene causing Type 2 Protein C deficiency and recurrent venous thrombosis, Blood Coagul Fibrinolysis 1993; 4: 345-347.

${ }^{72}$ P.J. Hallam, D.S. Millar, M. Krawczak, V.V. Kakkar and D.N. Cooper. Population differences in the frequency of the Factor V Leiden variant among people with clinically symptomatic Protein C deficiency. Med Genet 1995; 32: 543-545.

${ }^{73}$ D.S. Millar, D. Bevan, A. Chitolie, J. Reynaud, M. Chisholm, V.V. Kakkar and D.N. Cooper. Three novel mutations in the Protein C (PROC) gene causing venous thrombosis. Blood Coagul Fibrinolysis 1995; 6: 138-140.

${ }^{74}$ H. Priemé, S. Loft, M. Klarlund, K. Grønbæck, P. Tønnesen and H.E. Poulsen. Effect of smoking cessation on oxidative DNA modification estimated by 8-oxo-7,8-dihydro-2'-deoxyguanosine excretion. Carcinogenesis 1998; 19(2): 347-351.

${ }^{75}$ H. Priemé, K. Nyyssönen, K. Grønbæk, M. Klarlund, S. Loft, P. Tønnesen, J.T. Salonen and H.E. Poulsen. Randomized controlled smoking cessation study: transient increase in plasma high density lipoprotein but no change in lipoprotein oxidation resistance. Scand J Clin Lab Invest 1998; 58: 11-18. ${ }^{76}$ J. Lykkesfeldt, S. Loft, J.B. Nielsen and H.E. Poulsen. Ascorbic acid and dehydroascorbic acid as biomarkers of oxidative stress caused by smoking. Am J Clin Nutr 1997; 65: 959-963.

${ }^{77}$ H. Priemé, S. Loft, K. Nyssonen, J.T. Salonen and H.E. Poulsen. No effect of supplementation with vitamin E, ascorbic acid, or coenzyme Q10 on oxidative DNA damage estimated by 8-oxo-7,8-dihydro2'-deoxyguanosine excretion in smokers. Am J Clin Nutr 1997; 65: 503-507.

${ }^{78} \mathrm{~J}$. Clausen. Comparison of DNA adduct formation by means of synchronous scanning and by isotope tracers: in-vitro study on formation of DNA adducts in human lymphocytes exposed to benzo $(a)$ pyrene. Cancer Lett 1993; 72: 163-167. 
${ }^{79}$ T. Tefre, A.K. Daly, M. Armstrong, J.B. Leathart, J.R. Idle, A. Brogger and A.L. Borresen. Genotyping of the CYP2D6 gene in Norwegian lung cancer patients and controls. Pharmacogenetics 1994; 4(2): 47-57.

${ }^{80}$ S.J. London, A.K. Daly, J. Cooper, W.C. Navidi, C.L. Carpenter and J.R. Idle. Polymorphism of Gluthathione S-Transferase M1 and lung cancer risk among African-Americans and Caucasians in Los Angeles County, California. J Natl Cancer Inst 1995; 87(16): 1246-1253.

${ }^{81}$ S.J. London, A.K. Daly, J. Cooper, C.L. Carpenter, W.C. Navidi, L. Ding and J.R. Idle. Lung cancer risk in relation to the CYP2E1 Rsa I genetic polymorphism among African-Americans and Caucasians in Los Angeles County. Pharmacogenetics 1996; 6(2): 151-158.

${ }^{82}$ S.J. London, A.K. Daly, J.B. Leathart, W.C. Navidi and J.R. Idle. Lung cancer risk in relation to the CYP2C9*1/CYP2C9*2 genetic polymorphism among African-Americans and Caucasians in Los Angeles County, California. Pharmacogenetics 1996; 6(6): 527-533.

${ }^{83}$ S.J. London, A.K. Daly, J.B.S. Leathart, W.C. Navidi, C.C. Carpenter and J.R. Idle. Genetic polymorphism of CYP2D6 and lung cancer risk in African-Americans and Caucasians in Los Angeles County. Carcinogenesis 1997; 18: 1203-1214.

${ }^{84}$ J.B.S. Leathart, S.J. London, A. Steward, J.D. Adams, J.R. Idle and A.K. Daly. CYP2D6 phenotype - genotype relationships in African-Americans and Caucasians in Los Angeles. Pharmacogenetics 1998; 8: 529-541.

${ }^{85}$ S. Cholerton, A. Arpanahi, N. McCraken, C. Boustead, H. Taber, E. Johnstone, J. Leathert, A.K. Daly and J.R. Idle. Poor metabolisers of nicotine and CYP2D6 polymorphism. Lancet 1994; 343: 62 63.

${ }^{86}$ S. Cholerton, C. Boustead, H. Taber, A. Arpanahi and J.R. Idle. CYP2D6 genotypes in cigarette smokers and non-tobacco users. Pharmacogenetics 1996; 6: 261-263.

${ }^{87}$ C. Boustead, H. Taber, J.R. Idle, and S. Cholerton. CYP2D6 genotype and smoking behaviour in cigarette smokers. Pharmacogenetics 1997; 7: 411-414.

${ }^{88}$ J. Idle, F. Gonzalez [Editorial]. Pharmacogenetics 1991; 1: 1.

${ }^{89}$ [Inside cover]. Pharmacogenetics 1998 October; 8(5).

${ }^{90}$ BAT. Note from R.E. Thornton to B.D. Bramley, SRG Grants, 27 November 1991. Bates No. 300524526. Available from: http://old.ash.org.uk/html/conduct/pdfs/genetics/idlectr.pdf. Accessed: 31 October, 2008.

${ }^{91}$ J.R. Idle. Curriculum Vitae, July 1986. Bates No. 60074945-4970. Available from:

http://tobaccodocuments.org/ctr/CTRMN011057-1082.html. Accessed: 2008 October 31

${ }_{92}$ CTR. Scientific Advisory Board Members 1954-, 8 April 1995. Bates No. 60032100-2100. Available on: http://tobaccodocuments.org/ctr/60032100-2100.html. Accessed:October 31, 2008.

${ }^{93}$ R. Cooke. Genetics linked to lung cancer predisposition. The Record 1987 May 21. Council for Tobacco Research. Bates No. 11302575-2576. Available from: http://legacy.library.ucsf.edu/tid/bvy5aa00. Accessed: 31 October, 2008.

${ }^{94}$ CTR. Minutes of the Meeting of the Board of Directors, June 18, 1987. Bates No. 11067571. Available on: http://tobaccodocuments.org/ctr/CTRMIN-BD000200-0229.html. Accessed: 31 October, 2008.

${ }^{95}$ CTR. Minutes of the Meeting of the Board of Directors, June 18, 1987. Bates No. 11067571. Available on: http://tobaccodocuments.org/ctr/CTRMIN-BD000200-0229.html. Accessed: 31 October, 2008.

${ }^{96}$ CTR. Minutes of the Eighteenth Annual Meeting of Members, December 11, 1987. Bates no. 11067274-7284. Available on: http://tobaccodocuments.org/ctr/CTRMIN-MOM000245-0255.html. Accessed: 31 October, 2008.

${ }^{97}$ L.S. Zahn. Letter to Alan Campbell-Johnson, 14 January, 1988 (and enclosure). Bates No. 4010557744-5799. Available from: http://old.ash.org.uk/html/conduct/pdfs/genetics/zahnlet.pdf. Accessed: 31 October, 2008.

${ }^{98}$ SRG (undated). Details of Consultants Contracts. Bates No. 500874420-4422. Available from: http://old.ash.org.uk/html/conduct/pdfs/genetics/consu11.pdf Accessed: 31 October, 2008.

${ }^{99}$ SRG (undated). Details of Consultant Contracts. Bates No. 500874430-4433. Available from: http://old.ash.org.uk/html/conduct/pdfs/genetics/consu12.pdf. Accessed: 31 October, 2008. 
${ }^{100}$ R.E. Thornton. Note for Mr P Sheehy, Chairman, BAT Industries, 24 February, 1988. Bates No. 401055766. Available from: http://old.ash.org.uk/html/conduct/pdfs/genetics/sheehy.pdf. Accessed: 31 October, 2008.

${ }^{101}$ R.E. Thornton. Breathe North Appeal, 1 June, 1988. Bates No. 401055695. Available from: http://old.ash.org.uk/html/conduct/pdfs/genetics/appeal.pdf. Accessed: 31 October, 2008.

${ }_{102}$ N.B. Cannar. Letter to Department of Pharmacological Sciences: For the Attention of Professor J.R. Idle. 29 September, 1988. Bates No. 401055682-5684. Available from:

http://legacy.library.ucsf.edu/tid/ime11a99/pdf. Accessed: 31 October, 2008.

${ }^{103}$ CTR. Non-competitive renewal grant application (3119R2), 30 November, 1992. Bates No. 50308810-8815. Available from: http://legacy.library.ucsf.edu/tid/gqa00d00. Accessed: 31 October, 2008.

${ }^{104}$ R.F. Gertenbach. Letter to Dr Henry T. Lynch, Re: Grant No. 1297CR2, 4 January, 1990. Bates No. 60040508. Available from: http://tobaccodocuments.org/ctr/60040508-0508.html. Accessed: 31 October, 2008.

${ }^{105}$ R.F. Gertenbach. Letter to Dr Henry T. Lynch, Re: Grant No. 1297D, October 30, 1990. Bates No. 60040554. Available from: http://tobaccodocuments.org/ctr/60040554-0554.html . Accessed: 31 October, 2008.

${ }^{106}$ CTR. Non-competitive renewal grant application (3119R2), 30 November, 1992. Bates No. 50308810-8815. Available from: http://legacy.library.ucsf.edu/tid/gqa00d00. Accessed: 31 October, 2008.

${ }^{107}$ J.R. Idle. Renewal application, Pharmacogenetic Epidemiology of Lung Cancer, 30 November, 1993. Bates No. 50462744-2755. Available from: http://legacy.library.ucsf.edu/tid/gaw09d00. Accessed: 31 October, 2008.

${ }^{108}$ CTR. Funding history summary, Jeffrey R. Idle, SAB-rated Grant No: 3119. Bates No. 60035400. Available from: http://tobaccodocuments.org/ctr/60035400-5400.html. Accessed: 31 October, 2008.

${ }^{109}$ CTR. Non-competitive renewal grant application (3119R2), 30 November, 1992. Bates No. 50308810-8815. Available from: http://legacy.library.ucsf.edu/tid/gqa00d00. Accessed: 31 October, 2008.

${ }^{110}$ D. Ford. Memo to the committee comprising Drs Brennan and Sommers, re Henry T. Lynch, M.D., Creighton University, Omaha, NB $1^{\text {st }}$ Renewal Application No. 1297CR1 "A Case/Control Study of Breast and Lung Cancer with the addendum of the Debrisoquine Study”, 25 May, 1988, Bates No. 50316790-6790. Available from: http://legacy.library.ucsf.edu/tid/xoe00d00. Accessed: 31 October, 2008.

${ }^{111}$ M. Bloch. Tobacco industry funding of biomedical research. Tob Control 1994; 3: 297-298.

112 R.E. Thornton. [Letter to Dr J.R. Idle]. 7 April, 1988. British American Tobacco. Bates No. 401055748/5748. Available from: http://old.ash.org.uk/html/conduct/pdfs/genetics/idle grant.pdf. Accessed: 31 October, 2008.

${ }^{113}$ British American Tobacco. [Minutes of the Scientific Research Group Meeting - London, April 1820, 1988]. 1988. British American Tobacco. Bates No. 400313819-3821. Available from: http://old.ash.org.uk/html/conduct/pdfs/genetics/srg_mtg88.pdf . Accessed: 31 October, 2008. ${ }_{114}$ J.R. Idle. Research proposal, 2 September, 1988. Bates No. 401055536-5540. Available from: http://old.ash.org.uk/html/conduct/pdfs/genetics/idle_lc_prop.pdf. Accessed: 31 October, 2008.

${ }^{115}$ A.R. Feinstein. Letter to R.E. Thornton, 19 December, 1988. Bates No. 401055643-5646. http://old.ash.org.uk/html/conduct/pdfs/genetics/feinstein_review.pdf Accessed: 31 October, 2008.

${ }^{116}$ British American Tobacco. [Note on a Meeting with Dr Sydney Brenner, Windsor House, 30 March, 1988]. 1988. British American Tobacco. Bates No. 401055736/5737. Available from: http://old.ash.org.uk/html/conduct/pdfs/genetics/brenner.pdf. Accessed: 31 October, 2008.

${ }^{117}$ F.J.C. Roe. Comments on grant proposal from Jeffrey Idle, St. Mary's Hospital Medical School and University of Newcastle upon Tyne, 21 April, 1988. Bates No. 401055716-5718. Available from: http://old.ash.org.uk/html/conduct/pdfs/genetics/roe.pdf. Accessed: 31 October, 2008.

${ }^{118}$ V.A. McKusick. The Human Genome Organisation: History, purposes and membership. Genomics, 5, 385-387. Available from: http://www.hugo-international.org/abt history.php .Accessed: October 28, 2008.

${ }^{119}$ Sydney Brenner [CV]. Bates No. 2048373837/3840. Available from: http://legacy.library.ucsf.edu/tid/ayg74a00 . Accessed: 9 November 2009. 
${ }^{120}$ G. Ferry. 2001. Human Genome Project history 1: the project begins. Available from: http://genome.wellcome.ac.uk/doc_WTD022307.html. Accessed: 28 October, 2008.

${ }^{121}$ B. Balmer. Managing mapping in the Human Genome Project. Social Studies of Science 1996; 26: 531-73.

${ }^{122}$ J.R. Idle. [Letter to Ray Thornton, BATCo]. 18 March, 1988. British American Tobacco. Bates No. 401055755/5756. Available from: http://old.ash.org.uk/html/conduct/pdfs/genetics/idle_let.pdf . Accessed: 31 October, 2008.

${ }^{123}$ N. Caporaso, R. Hoover, S. Aisner, J. Resau B. Trump, H. Issaq, G. Muschik, and C.C. Harris Debrisoquine metabolic phenotype and the risk of lung cancer [Abstract]. Proceedings of the $24^{\text {th }}$ Annual Meeting of the American Society of Clinical Oncology; 22-24 May, 1988; New Orleans, USA. ${ }^{124}$ G. Kolata. Scientists pinpoint genetic changes that predict cancer. New York Times 16 May, 1989. Available from: http://old.ash.org.uk/html/conduct/pdfs/genetics/nyt160589.pdf. Accessed: 31 October, 2008.

${ }^{125}$ Anon. [Speech]. Undated. Council for Tobacco Research. Bates No. 60035145/5151. Available from: http://legacy.library.ucsf.edu/tid/mmx20a00. Accessed: 31 October, 2008.

${ }^{126}$ Council for Tobacco Research. [Minutes of Staff Meeting, 2 August, 1989]. Council for Tobacco Research. Bates No. 60034608-4609. Available from: http://legacy.library.ucsf.edu/tid/kxw20a00. Accessed: 31 October, 2008.

${ }_{127}$ J.R. Idle. [Letter to James F. Glenn] 20 December, 1989. Council for Tobacco Research. Bates No. 50316730/6731. Available from: http://legacy.library.ucsf.edu/tid/ope00d00. Accessed: 31 October, 2008.

${ }^{128}$ R.F. Gertenbach. Letter to Dr Henry T. Lynch, Re: Grant No. 1297CR2, 4 January, 1990. Bates No. 60040508. Available on: http://tobaccodocuments.org/ctr/60040508-0508.html. Accessed: 31 October, 2008.

${ }^{129}$ I. Roots, N. Drakoulis, M. Ploch, G. Heinemeyer, R. Loddenkemper, T. Minks, M. Nitz, F. Otte and $\mathrm{M}$. Koch. Debrisoquine hydroxylation phenotype, acetylation phenotype and ABO blood groups as genetic host factors of lung cancer risk. Klin Wochenschr 1988; 66: 87-97.

${ }^{130}$ C.J. Spiers, S. Murray, D.S. Davies, A.F. Biolamabadeje and A.R. Boobis. Debrisoquine oxidation phenotype and susceptibility to lung cancer. Br J Clin Pharmacol 1990; 29, 101-109.

${ }^{131}$ J. Benítez, J.M. Ladero, C. Jura, J.A. Carrillo, J. Cobaleda, A. Llerena, E. Vargas and J.J. Muñoz. Polymorphic oxidation of debrisoquine in lung cancer patients. Eur J Cancer 1991; 27(2): 158-161.

132 J-C. Duche, C. Joanne, J. Barre, H. de Cremoux, J.C. Dalphin, A. DePierre, P. Brochard, J.P.

Tillement and P. Bechtel. Lack of a relationship between the polymorphism of debrisoquine oxidation and lung cancer. Br J Clin Pharmacol 1991; 31: 533-536.

${ }^{133}$ Wolf CR, Smith CAD, Gough AC, Moss JE, Vallis KA, Howard G, Carey FJ, Mills K, McNee W, Carmichael J, Spurr NK. Relationship between the debrisoquine hydroxylase polymorphism and cancer susceptibility. Carcinogenesis 1992; 13, 1035-1038.

${ }^{134}$ J.R. Idle. Is environmental carcinogenesis modulated by host polymorphism? Mutat Res 1991; 247(2): 259-266.

${ }^{135}$ J.R. Idle, M. Armstrong, A.V. Boddy, C.Boustead, S. Cholerton, J. Cooper, A.K. Daly, J. Ellis, W. Gregory, H., C. Höfer, J. Holt, J. Leathart, N. McCraken, S.C. Monkman, J.E. Painter, H. Taber, D. Walker and M. Yule. The pharmacogenetics of chemical carcinogenesis. Pharmacogenetics 1992; 2: 246-258.

${ }^{136}$ A.K. Daly, S. Cholerton, W. Gregory and J.R. Idle. Metabolic polymorphisms. Pharmac Ther 1993; 57: $129-160$.

${ }^{137}$ F.J. Gonzalez, J.R. Idle. Pharmacogenetic phenotyping and genotyping. Present status and future potential. Clinical Pharmacokinetic Concepts 1994; 26(1): 59-70.

${ }^{138}$ A.K. Daly, S. Cholerton, M. Armstrong and J.R. Idle. Genotyping for polymorphisms in xenobiotic metabolism as a predictor of disease susceptibility. Environ Health Perspect 1994; 102 Suppl 9: 55-61. ${ }^{139}$ J.R. Idle and A.K. Daly. New opportunities in cancer risk evaluation using PCR-based DNA analysis for CYP2D6. Environ Health Perspect 1993; 101 Suppl 3: 117-120.

${ }^{140}$ CTR. Non-competitive renewal grant application (3119R1), 4 December, 1991. Bates No. 50308832-8840. Available from: http://legacy.library.ucsf.edu/tid/hpa00d00. Accessed: 31 October, 2008. 
${ }^{141}$ C.R. Wolf, C.A.D. Smith, T. Bishop, D. Forman, A.C. Gough and N.K. Spurr. CYP2D6 genotyping and the association with lung cancer susceptibility. Pharmacogenetics 1994; 4: 104-106.

142 S.J. London, A.K. Daly, D.C. Thomas, N.E. Caporaso and J.R. Idle. Methodological issues in the interpretation of studies of the CYP2D6 genotype in relation to lung cancer risk. Pharmacogenetics 1994; 4: 107-108.

${ }^{143}$ P.M. Christensen, P.C. Gøtzsche and K. Brøsen. The sparteine/debrisoquine (CYP2D6) oxidation polymorphism and the risk of lung cancer: a meta analysis. Eur J Clin Pharmacol 1997; 51: 389-393.

144 A. Rostami-Hodjegan, M.S. Lennard, H.F. Woods and G.T. Tucker. Meta-analysis of studies of the CYP2D6 polymorphism in relation to lung cancer and Parkinson's disease. Pharmacogenetics 1998; 8: 227-238.

${ }^{145}$ A.K. Daly and C.P. Day. Candidate gene case-control association studies: advantages and potential pitfalls. Br J Clin Pharmacol 2001; 52: 489-499.

${ }^{146}$ W.T. Hoyt. [Letter to Henry Rothschild]. 22 April, 1977. Council for Tobacco Research. Bates No. 11014713/4713. CTR SP-FILES 014694/4694. Available from:

http://legacy.library.ucsf.edu/tid/lvh8aa00. Accessed: 31 October, 2008.

${ }^{147}$ T.M. Finnegan. [Letter to William W. Shinn, Esq]. 17 February, 1978. Council for Tobacco

Research. Bates No. 521032033/2033. Available from: http://legacy.library.ucsf.edu/tid/vnx33f00. Accessed: 31 October, 2008.

${ }^{148}$ Special Report, Days Two and Three: The Waxman Hearings. Tobacco Institute Newsletter, Number 301, 12 March, 1982. Bates No. HK0329104-911. Available from: http://tobaccodocuments.org/ctr/HK0329104-9111.html. Accessed: 31 October, 2008.

${ }^{149}$ T.M. Finnegan. Memorandum for Messrs. Greer, Henson, Holzman, Pepples, Stevens, Witt, Re: Dr Henry Rothschild, February 15, 1982. Bates No. 521031876-1877. Available from:

http://tobaccodocuments.org/ness/604.html. Accessed: 31 October, 2008.

${ }^{150}$ W.T. Hoyt. Letter to Henry Rothschild, 13 April, 1982. Bates No. 11022695. CTR SP-FILES 022677. Available from: http://tobaccodocuments.org/ctr/CTRSP-FILES022677-2677.html. Accessed: 31 October, 2008.

${ }^{151}$ W.T. Hoyt. [Letter to Henry Rothschild]. 13 April, 1982. Council for Tobacco Research. Bates No. 11022695/2695. CTRSP-FILES022677/2677. Available from:

http://legacy.library.ucsf.edu/tid/mzk8aa00. Accessed: 31 October, 2008.

${ }_{152}$ W.T. Hoyt. [Letter to Henry Rothschild]. 7 June, 1983. Council for Tobacco Research. Bates No. 11022660/2660. CTRSP-FILES022642/2642. Available from:

http://legacy.library.ucsf.edu/tid/bzk8aa00. Accessed: 31 October, 2008.

${ }^{153}$ R.F. Gertenbach. [Letter to Henry Rothschild]. 28 August, 1986. Council for Tobacco Research. Bates No. 11026264/6264. CTRSP-FILES026246/6246. Available from: http://legacy.library.ucsf.edu/tid/nfm8aa00. Accessed: 31 October, 2008.

${ }^{154}$ R.F. Gertenbach. [Letter to Henry Rothschild]. 12 January, 1988. Council for Tobacco Research. Bates No. 60113506/3506. Available from: http://legacy.library.ucsf.edu/tid/suw30a00. Accessed: 31 October, 2008.

${ }^{155}$ W.L. Ooi, R.C. Elston, V.W. Chen, J.E Bailey-Wilson and H. Rothschild. Increased familial risk for lung cancer. J Natl Cancer Inst 1986; 76(2): 217-212.

${ }^{156}$ W.L. Ooi, R.C. Elston, V.W. Chen, J.E Bailey-Wilson and H. Rothschild.. Familial lung cancer correcting an error in calculation. J Natl Cancer Inst 1986; 77(4): 990.

${ }^{157}$ T.A. Sellers, W.L. Ooi, R.C. Elston, V.W. Chen, J.E. Bailey-Wilson and H. Rothschild. Increased familial risk for non-lung cancer among relatives of lung cancer patients. Am J Epidemiol 1987; 126(2): 237-246.

${ }^{158}$ T.A. Sellers, R.C. Elston, C. Stewart and H. Rothschild. Familial risk of cancer among randomly selected cancer probands. Genet Epidemiol 1988; 5(6): 381-391.

${ }^{159}$ N.E. Caporaso, M.A. Tucker, R.N. Hoover, R.B. Hayes, L.W. Pickle, H.J. Issaq, G.M. Muschik, L. Green-Gallo, D. Buivys, S. Aisner, J.H. Resau, B.F. Trump, D. Tollerud, A. Weston and C.C. Harris. Lung cancer and the debrisoquine metabolic phenotype. J Natl Cancer Inst 1990; 82: 1264-1272.

${ }^{160}$ T.A. Sellers, J.E. Bailey-Wilson, R.C. Elston, A.F. Wilson, G.Z. Elston and H. Rothschild. Evidence for Mendelian inheritance in the pathogenesis of lung cancer. J Natl Cancer Inst 1990; 82: 1272-1279. 
${ }^{161}$ R.E. Thornton. [Note For Mr B.D. Bramley: Genetic Predisposition to Lung Cancer]. 12 September, 1990. British American Tobacco. Bates No: 300506580/6580. Available from: http://old.ash.org.uk/html/conduct/pdfs/genetics/1990papers note.pdf. Accessed: 31 October, 2008. ${ }_{162}$ J. Foreman. Researchers say heredity plays a key role in lung cancer. The Boston Globe, 1 August, 1990. Available on: http://legacy.library.ucsf.edu/tid/hfq39e00.

${ }^{163}$ M. Waldholz. Lung cancer risk linked to heredity. Wall Street Journal, 1 August, 1990. Available on: http://legacy.library.ucsf.edu/tid/jgr31a00

${ }^{164}$ M. Gladwell. Gene linked to lung cancer. The Washington Post, 2 August, 1990.

165 A.E. Reif. Heredity as a determining factor in which smokers die of lung cancer. J Natl Cancer Inst 1991; 83(1): 64.

166 T.A. Sellers, R.C. Elston, L.D Atwood and H. Rothschild. Lung cancer histologic type and family history of cancer. Cancer 1992; 69(1): 86-91.

${ }^{167}$ J.E. Bailey-Wilson, T.A. Sellers, R.C. Elston, C.C. Evens and H. Rothschild. Evidence for a major gene effect in early-onset lung cancer. Journal of the LA State Medical Society 1993; 145: 157-162.

${ }^{168}$ T. A. Sellers, J.D. Potter, J.E. Bailey-Wilson, S.S. Rich, H. Rothschild and R.C. Elston. Lung cancer detection and prevention: evidence for an interaction between smoking and genetic predisposition. Cancer Res (Suppl.) 1992; 52: 2694s-2697s.

${ }^{169}$ T.A. Sellers, J.E. Bailey-Wilson, J.D. Potter, S.S. Rich, H. Rothschildand R.C. Elston. Effect of cohort differences in smoking prevalence on models of lung cancer susceptibility. Genet Epidemiol 1992; 9(4): 261-271.

${ }^{170}$ T.A. Sellers, P-L. Chen, J.D. Potter, J.E. Bailey-Wilson, H. Rothschild, R.E.C. Elston. Segregation analysis of smoking-associated malignancies: evidence for Mendelian inheritance. Am J Med Genet 1994; 52: 308-314.

${ }^{171}$ Anon, SRG Budget 1992; BATCo Smoking and Health Budget 1992. Bates No. 300528514-8515. Available from: http://old.ash.org.uk/html/conduct/pdfs/genetics/srg_92 bud.pdf Accessed: 31 October, 2008.

172 British American Tobacco [Minutes of the SRG Meeting, Copenhagen, Denmark, 7-9 June, 1993 ]. 1993. British American Tobacco. Bates No. 566401259/1266. Available from: http://old.ash.org.uk/html/conduct/pdfs/genetics/srg mins93 june.pdf. Accessed: 31 October, 2008. ${ }^{173}$ L.J. Rudge and R.E. Thornton [Minutes of the SRG Meeting, Viking Inn, Montreal, Canada, 5-7 May, 1992]. 1992. British American Tobacco. Bates No. 400501290/1297. Available from: http://old.ash.org.uk/html/conduct/pdfs/genetics/srg_92.pdf. Accessed: 31 October, 2008.

${ }^{174}$ SRG. Minutes of the SRG Meeting, New York, US, 28-30 October, 1993. Available from: http://old.ash.org.uk/html/conduct/pdfs/genetics/srg_mins_93_oct.pdf. Accessed: October 31, 2008.

${ }^{175}$ L. Rudge [BATCo memo to SRG members]. 15 February, 1995. British American Tobacco. Bates No. 500833937/3947. Available from: http://old.ash.org.uk/html/conduct/pdfs/genetics/srg_95.pdf. Accessed: 31 October, 2008.

${ }^{176}$ W.J. Gauderman, J.L. Morrison, C.L. Carpenter and D.C. Thomas. Analysis of gene-smoking interaction in lung cancer. Genet Epid 1997; 14: 199-214.

${ }^{177}$ W.J. Gauderman and J.L. Morrison. Evidence for age-specific relative risks in lung cancer. Am J Epid 2000 151: 41-49.

${ }^{178}$ NIH Grants and Awards for Fiscal Year 2000: Awards in the State of Louisiana Effective 03/06/2001. Available from: http://grants.nih.gov/grants/award/state/fy2000.louisian.txt._Accessed: 31 October, 2008.

${ }^{179}$ J.E. Bailey-Wilson, C.I. Amos, S.M. Pinney, G.M. Petersen, M. de Andrade, J.S. Wiest, P. Fain, A.G. Shwartz, M. You, W. Franklin, C. Klein, A. Gazdar, H. Rothschild, D. Mandal, T. Coons, J. Slusser, J. Lee, C. Gaba, E. Kupert, A. Perez, X. Zhou, D. Zeng, Q. Liu, Q. Zhang, D. Seminara, J. Minna and M.W. Andersen. A major lung cancer susceptibility locus maps to chromosome 6q23-25. Am. J. Hum. Genet 2004; 75(3):460-74.

${ }^{180} \mathrm{~T}$. Bonfield. Lung cancer gene region identified: US study paves way for screening test. The Cincinnati Enquirer. 25 July, 2004.

${ }^{181}$ Anon. Rare mutation sends lung cancer risk through the roof. New Scientist. 7 August, 2004. ${ }^{182}$ K. Augé. Lung-cancer study points to gene, not just smoking. The Denver Post. 27 July, 2004.

${ }^{183}$ P. Liu, H.G. Vikis, D. Wang, Y. Lu, Y. Wang, A.G. Scwartz, S.M. Pinney, P. Yang, M. de Andrade, G.M. Petersen, J.S. Wiest, P.R. Fain, A. Gazdar, C. Gaba, H. Rothschild, D. Mandal, T. Coons, J. Lee, 
E. Kupert, D. Seminara, J. Minna, J.E. Bailey-Wilson, X. Wu, M.R. Spitz, T. Eisen, R.S. Houlston, C.I. Amos, M.W. Anderson and M. You. Familial aggregation of common sequence variants 15q24-25.1 in lung cancer. J. Natl. Cancer Inst 2008; 100(18): 1326-1330.

${ }^{184}$ C.I. Amos, X. Wu, P. Broderick et al. Genome-wide association scan of tag SNPs identifies a susceptibility locus for lung cancer at 15q25.1. Nat. Genet 2008; 40(5): 616-622.

${ }^{185}$ R.J. Hung, J.D. McKay, V. Gaborieau et al. A susceptibility locus for lung cancer maps to nicotinic acetylcholine receptor subunit genes on 15q25. Nature 2008; 452(7187):633-637.

${ }^{186}$ T.E. Thorgeirsson, F. Geller, P. Sulem et al. A variant associated with nicotine dependence, lung cancer and peripheral arterial disease. Nature 2008; 452(7187): 638-642.

${ }^{187}$ R.E. Thornton. Note for the Tobacco Strategy Group, 2 December, 1993. Bates No. 5025206690672. Available from: http://old.ash.org.uk/html/conduct/pdfs/genetics/srg 93.pdf. [ $2^{\text {nd }}$ document] Accessed: 31 October, 2008. (Note, there is a discrepancy in the documents as eight years would imply this work was funded from 1986 not 1987.)

${ }^{188}$ J.K. Field, Z.P. Pavelic, D.A. Spandidos, P.J. Stambrook, A.S. Jones and J.L. Gluckman. The role of the p53 tumor suppressor gene in sqamous cell carcinoma of the head and neck. Arch OtolaryngolHead and Neck Surgery 1993; 119: 1118-1122.

${ }^{189}$ H.T. Hiilamo. The impact of strategic funding by the tobacco industry of medical expert witnesses appearing for the defence in the Aho Finnish product liability case. Addiction 2007; 102: 979-988.

${ }^{190}$ BAT. Note from Smoking Issues Department, Memo from L Rudge to S. Appleton et al., SRG

Grant Renewal from Dr Field, 16 February, 1994. Bates No. 400729288-9304. BAT, Memo from T.G. Mitchell to L Rudge, 1 March, 1994. Bates No. 400729284._Available from:

http://old.ash.org.uk/html/conduct/pdfs/genetics/field_p53 renewal.pdf. Accessed: 31 October, 2008.

${ }^{191}$ SRG. Minutes of the SRG Meeting, London, 18-19 April, 1994. Bates No. 500834094-4097.

Available from: http://old.ash.org.uk/html/conduct/pdfs/genetics/srg_min94.pdf. Accessed: 31 October, 2008.

192 M. Krawczak, and D.N. Cooper. P53 mutations, benzo[a]pyrene and lung cancer. Mutagenesis 1998; 13 (4): 319-320.

${ }^{193}$ M. Krawczak, B. Smith-Sorensen, J. Schmidtke, V.V. Kakkar, D.N. Cooper and E. Hovig. Somatic specturm of cancer-associated single base-pair substitutions in the TP53 gene is determined mainly be endogenous mechanisms of mutationand by selection. Human Mutations 1995; 5: 48-57.

${ }_{195}^{194}$ [nside cover]. Mutagenesis $1986 \mathrm{Jul} ;$ 9(4).

195 [Inside cover]. Mutagenesis 2001 Nov; 16(6).

196 BAT. Memo from R.E. Thornton to B.D. Bramley, 17 May, 1993. Bates No. 400501185-1187. Available from: http://old.ash.org.uk/html/conduct/pdfs/genetics/srg_procs.pdf Accessed: 31 October, 2008.

${ }^{197}$ BAT. Memo from R.E. Thornton to B.D. Bramley, 25 August, 1993. Bates No. 300525752. R.E. Thornton. Note for the Tobacco Strategy Group, 2 December. 1993. Bates No. 502520669-0672. Available from: http://old.ash.org.uk/html/conduct/pdfs/genetics/srg_93.pdf. Accessed: 31 October, 2008.

${ }^{198}$ A.R. Tricker. Memo to the SSRC, 8 August, 1998. Bates No. 2063595219. Available from: http://tobaccodocuments.org/pm/2063595219.html. Accessed: 31 October, 2008.

${ }^{199}$ SRG. SRG Research Projects -1992. Bates No. 510100048-0051. Available from: http://old.ash.org.uk/html/conduct/pdfs/genetics/srg_proj92.pdf . Accessed: 31 October, 2008.

${ }^{200}$ R.E. Thornton. Visit to the Thrombosis Research Unit (TRI), 8 June, 1992. Bates No. 40050128401285. Available from: http://old.ash.org.uk/html/conduct/pdfs/genetics/cooper thromb proj.pdf. Accessed: 31 October, 2008.

${ }^{201}$ SRG. Minutes of the SRG Meeting, Copenhagen, Denmark, 7-9 June, 1993. Bates No. 566401259566401266. Available from:

http://old.ash.org.uk/html/conduct/pdfs/genetics/srg_mins93 june.pdf. Accessed: 31 October, 2008. ${ }^{202}$ SRG. Minutes of the SRG Meeting, New York, US, 28-30 October, 1993. Bates No. 400500863400500868. Available from: http://old.ash.org.uk/html/conduct/pdfs/genetics/srg_mins_93_oct.pdf. Accessed: 31 October, 2008.

${ }^{203}$ R.E. Thornton. Visit to Prof Dr U. Mohr, Dr M. Krawczak and Dr Koch, Medical Technical High School, Hannover, 5-6 September, 1993. Bates No: 500833681-3682. Available from: http://tobaccodocuments.org/guildford misc/500833681-3682.html . Accessed: 31 October, 2008. 
${ }^{204}$ L. Rudge. Memo to the Scientific Research Group, 7 July, 1994. Bates No. 500833961. Available from: http://old.ash.org.uk/html/conduct/pdfs/genetics/rudge.pdf . Accessed: 31 October, 2008.

${ }^{205}$ L. Rudge. Memo to SRG members, 20 March 1995. Bates No. 500833908-3911. Available from: http://old.ash.org.uk/html/conduct/pdfs/genetics/srg_smoke_cancer.pdf Accessed: 31 October, 2008.

${ }^{206}$ J.M. Boullin. p53 tumour suppressor gene and the tobacco industry [letter]. Lancet 2005; 365: 567.

${ }^{207}$ H.E. Poulsen (undated). Proposal for a 3 year research programme on: oxidative DNA damage in smokers and the effect of antioxidant intervention and smoking cessation. Bates No. 400728890-8894. Available from: http://legacy.library.ucsf.edu/tid/vdy87a99 Accessed: 31 October, 2008.

${ }^{208}$ H. Vainio. Chemoprevention of cancer: a controversial and instructive story. Br Med Bull 1999; 55(3): 593-599.

${ }^{209}$ G.S. Omenn, G.E. Goodman, M.D. Thornquist, J. Balmes, M.R. Cullen, A. Glass, J.P. Keogh, F.L. Meyskens, B. Valanis, J.H. Williams, S. Barnhart and S. Hammar. Effects of a combination of beta carotene and vitamin A on lung cancer and cardiovascular disease. N Engl J Med 1996; 334: 11501155 .

${ }^{210}$ The Alpha-Tocopherol BCCPSG. The effect of vitamin E, beta carotene on the incidence of lung cancer and other cancers in male smokers. N Engl. J. Med 1994; 330: 1029-1035.

${ }^{211}$ G.S. Omenn. Chemoprevention of lung cancers: lessons from CARET, for the beta-carotene and retinol efficacy trial, and prospects for the future. Eur. J. Cancer Prev 2007; 16: 184-191.

${ }^{212}$ M. Jarvis, H. Tunstall-Pedoe, C. Feyerbend, C. Vesey and Y. Saloojee. Comparison of tests used to distinguish smokers from nonsmokers. Am J Public Health 1987; 77: 1435-1438.

${ }^{213}$ M.J. Jarvis, A.D. McNeil, M.A.H. Russel, R.J. West, A. Bryant and C. Feyerabend. Passive smoking in adolescents: one-year stability of exposure in the home [letter]. Lancet 1987; i: 1324-1325.

${ }^{214}$ M. Pottorff. Memo to Cynthia von Maerestetten, Philip Morris International Inc., 10 March, 1989.

Bates No. 2023553805. Available from: http://tobaccodocuments.org $/ \mathrm{pm} / 2023553805$.html. Accessed: 31 October, 2008.

${ }^{215}$ A. Whist. Memo to R.W. Murray, Philip Morris International Inc., 16 March, 1989. Bates No. 2024255430. Available from: http://tobaccodocuments.org/pm/2024255430.html . Accessed: 31 October, 2008.

${ }^{216}$ J.R. Idle. Titrating exposure to tobacco smoke using cotinine: A minefield of misunderstandings. Fax dated 4 July, 1989. Bates No. 2023559123-9139. Available from: http://tobaccodocuments.org/pm/2023559123-9139.pdf. Accessed: 31 October, 2008.

${ }^{217}$ A.R. Feinstein. Letter to J.R. Idle, 19 October, 1989. Bates No. 401055476. Available from: http://old.ash.org.uk/html/conduct/pdfs/genetics/feinstein_note.pdf. Accessed: 31 October, 2008.

${ }^{218}$ J.R. Idle. Compliment slip, November 1989. Bates No. 401055475. Available from: URL: http://old.ash.org.uk/html/conduct/pdfs/genetics/idleslip.pdf . Accessed: 31 October, 2008.

219 J.R. Idle. CYP2A6 polymorphism, nicotine, and environmental nitrosamines [Letter]. Lancet 1999; 353: 2073 .

${ }^{220}$ J.R. Idle. [Letter to James F. Glenn] 20 December, 1989. Council for Tobacco Research. Bates No. 50316730/6731. Available from: http://legacy.library.ucsf.edu/tid/ope00d00. Accessed: 31 October, 2008.

${ }^{221}$ S. Brenner. Letter to Mr Charles Wall, Philip Morris. 31 August, 1994. Bates No. 2046660254/0255. Available from: http://legacy.library.ucsf.edu/tid/xx124c00 . Accessed: November 9 , 2008.

${ }^{222}$ J. Cohen. Tobacco money lights up a debate. Science 1996; 272; 488-494.

${ }^{223}$ Mutual Release And Termination Agreement. 1 July, 1996. Bates No. 2072809088/9090. Available from: http://legacy.library.ucsf.edu/tid/zfs95c00/pdf. Accessed: October 28, 2008. ${ }^{224}$ A. Petersen. Biofantasies: genetics and medicine in the print news media. Soc Sci Med 2001; 52: $1255-1268$.

${ }^{225}$ C.D. Bates. Smoking and dissonance: smokers' needs in promoting the treatment of tobacco dependence. J Clin Psychiatry Monograph 2003; 18(1): 92-100.

${ }^{226}$ J.P.A. Ioannidis, T.A. Trikalinos, E.E. Ntzani, and D.G. Contopoulos-Ionnidis. Genetic associations in large versus small studies: an empirical assessment. Lancet 2003; 361: 567-571.

${ }^{227}$ T.J. Kaptchuk. Effect of interpretative bias on research evidence. Br Med J 2003; 326: 1453-1455. 
${ }^{228}$ J.D. Hayes and D.J. Pufford. The glutathione S-transferase supergene family: regulation of GST and the contribution of the isoenzymes to cancer chemoprotection and drug resistance. Crit Rev Biochem Mol Biol 1995; 30: 445-600.

${ }^{229}$ S. Anttila, A. Hirvonen, H. Vainio, K. Husgafel-Pursiainen, J.D. Hayes and B. Ketterer. Immunohistochemical localization of glutathione S-transferases in human lung. Cancer Res 1993; 53: 5643-48.

${ }^{230}$ K.T. Kivisto, E-U. Griese, T. Stuven et al. Analysis of CYP2D6 expression in human lung: implications for the association between CYP2D6 activity and susceptibility to lung cancer. Pharmacogenetics 1995; 7:295-302.

${ }^{231} \mathrm{~S}-\mathrm{W}$. Guo. Familial aggregation of environmental risk factors and familial aggregation of disease. Am J Epid 2000; 151(11) : 1121-1131.

${ }^{232}$ P. McGuffin and P. Huckle. Simulation of Mendelism revisited: the recessive gene for attending medical school. Am J Hum Genet 1990; 46: 994-999.

${ }^{233}$ P. Vineis, P. Schulte and A.J. McMichael. Misconceptions about the use of genetic tests in populations. Lancet 2001; 357: 709-712.

${ }^{234}$ T. Paz-Elizur, M. Krupsky, S. Blumenstein, D. Elinger, E. Schechtman and Z. Livneh. DNA repair activity for oxidative damage and risk of lung cancer. J Natl Cancer Inst 2003; 95(17): 1312-19.

${ }^{235}$ JNCI. Press release. DNA repair activity may be associated with risk of lung cancer. 3 September, 2003. Available from: http://jncicancerspectrum.oupjournals.org/cgi/content/full/jnci;95/17/1257-a. Accessed: 31 October, 2008.

${ }^{236}$ Reuters Health Information. Lower levels of DNA-repair enzyme associated with lung cancer risk. 3 September, 2003.

${ }^{237}$ N. Hawkes. Test will show which smokers face lung cancer death. The Times 3 September, 2003.

${ }^{238}$ D. Demetriou. Gene link to lung cancer could lead to early blood test. The Independent 3 September, 2003.

${ }^{239}$ Anon. Smokers' death test. The Sun 3 September, 2003.

240 Anon. The battles to come. The Economist 5 September, 2003.

${ }^{241}$ R.F. Gertenbach. [Letter to Zvi Livneh]. 15 May, 1985. CTR. Bates No. 50181958/1958. Available on: http://legacy.library.ucsf.edu/tid/jtu69c00. Accessed: 31 October, 2008.

${ }^{242}$ R.F. Gertenbach. [Letter to Zvi Livneh]. 14 April, 1986. CTR. Bates No. 50181939/1939. Available on: http://legacy.library.ucsf.edu/tid/nuu69c00. Accessed: 31 October, 2008.

${ }^{243}$ R.F. Gertenbach. [Letter to Zvi Livneh]. 4 May, 1987. CTR. Bates No. 50181909/1909. Available on: http://legacy.library.ucsf.edu/tid/xtu69c00. Accessed: 31 October, 2008.

${ }^{244}$ R.F. Gertenbach. [Letter to Zvi Livneh]. 9 May, 1988. CTR. Bates No. 50181866/1866. Available on: http://legacy.library.ucsf.edu/tid/zvu69c00. Accessed: 31 October, 2008.

${ }^{245}$ R.F. Gertenbach. [Letter to Zvi Livneh]. 26 April, 1989. CTR. Bates No. 50181820/1820. Available on: http://legacy.library.ucsf.edu/tid/ubu69c00. Accessed: 31 October, 2008.

${ }^{246}$ R.F. Gertenbach. [Letter to Zvi Livneh]. 25 April, 1990. CTR. Bates No. 50181800/1800. Available on: http://legacy.library.ucsf.edu/tid/hqu69c00. Accessed: 31 October, 2008.

${ }^{247}$ R.F. Gertenbach. [Letter to Zvi Livneh]. 3 May, 1991. CTR. Bates No. 50181763/1763. Available on: http://legacy.library.ucsf.edu/tid/hwu69c00. Accessed: 31 October, 2008.

${ }^{248}$ J.R. Idle. Pharmacogenetics in the new patterns of healthcare delivery. Pharmacogenetics 1995; 5:347-350.

${ }^{249}$ F.S. Collins. Shattuck lecture - medical and societal consequences of the Human Genome Project. N. Engl. J. Med; 341: 28-37.

${ }^{250}$ T. Blair. Speech to the Royal Society. 23 May, 2002. http://politics.guardian.co.uk/speeches/story/0,11126,721029,00.html. Accessed: October 28, 2008.

${ }^{251}$ Department of Health (UK). Our inheritance, our future: realising the potential of genetics in the NHS. London: HMSO; June, 2003. Cm5791-II.

${ }^{252}$ The Wellcome Trust Case Control Consortium. Genome-wide association study of 14,000 cases of seven common diseases and 3,000 shared controls. Nature 2007; 447, 661-678.

${ }^{253}$ S.J. Gardiner and E.J. Begg. Pharmacogenetics, drug-metabolizing enzymes, and clinical practice. Pharmacological Reviews 2006; 58(3): 521-590. 
${ }^{254}$ A.C.J.W. Janssens, M. Gwinn, L.A. Bradley, B.A. Oostra, C.M. van Duijn and M.J. Khoury. A critical appraisal of the scientific basis of commercial genomic profiles used to assess health risks and personalize health interventions. Am. J. Hum. Genet 2008; 82: 593-599.

${ }^{255}$ S.G. Baker and J. Kaprio. Common susceptibility genes for cancer: search for the end of the rainbow. British Medical Journal 2006; 332, 1150-1152.

${ }^{256}$ J. Jakobsdottir, M.B. Gorin, Y.P. Conley, R.E. Ferrell and D.E. Weeks. Interpretation of genetic association studies: markers with replicated highly significant odds ratios may be poor classifiers. PLoS Genetics 2009; 5(2), e1000337.

${ }^{257}$ Wallace HM. Most gene test sales are misleading. Nat. Biotech. 2008; 26(11), 716.

${ }^{258}$ Kaye J (2006) Police collection and access to DNA samples. Genomics, Society and policy, 2(1), 16-27. http://www.gspjournal.com Accessed: 2008: October 28.

${ }^{259}$ Nelkin D (1994) Promotional metaphors and their popular appeal. Public Understanding of Science, 3, 25-31.

${ }^{260}$ F. Gannon. Hope, hype and hypocrisy. EMBO Reports 2007; 8, 12, 1087.

http://www.nature.com/embor/journal/v8/n12/full/7401129.html. Accessed: October 28, 2008.

${ }^{261}$ H.M. Wallace. The development of UK Biobank: Excluding scientific controversy from ethical debate. Critical Public Health 2005; 15(4): 323-333.

${ }^{262}$ H. Rose. 1994. Love, power and knowledge. Cambridge: Polity Press.

${ }^{263}$ P. Nightingale and P.A. Martin. The myth of the biotech revolution. Trends Biotech 2004; 22 (11): $564-569$.

${ }^{264}$ G. Lewison, G. Dawson and J. Anderson. Support for UK biomedical research from the tobacco industry. Lancet 2003; 349, 778.

${ }^{265}$ H.M. Wallace. 2009. Genetic screening for susceptibility to disease. In: Encyclopedia of Life Sciences. Chichester: John Wiley \& Sons Ltd. Available from:

http://mrw.interscience.wiley.com/emrw/9780470015902/els/article/a0021790/current/pdf. 


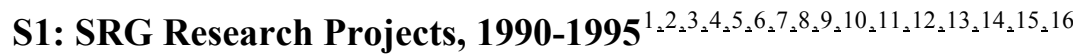

\begin{tabular}{|c|c|c|c|}
\hline $\begin{array}{l}\text { Lead } \\
\text { Researcher }\end{array}$ & Institution & Project & Funding (*) \\
\hline Professor JR Idle & $\begin{array}{l}\text { Department of } \\
\text { Pharmacological } \\
\text { Sciences, } \\
\text { University of } \\
\text { Newcastle Upon Tyne, } \\
\text { UK }\end{array}$ & $\begin{array}{l}\text { Cytochrome P450 } \\
\text { polymorphisms }\end{array}$ & $\begin{array}{l}\text { 1989: } 556 \mathrm{k} \\
\text { 1990: } 172 \mathrm{k} \\
\text { 1991: } £ 85.1 \mathrm{k} \\
\text { 1992: } 888.7 \mathrm{k} \\
\text { 1993: } 966 \mathrm{k}\end{array}$ \\
\hline Dr AK Daly & $\begin{array}{l}\text { Pharmacogenetics } \\
\text { Research Unit, } \\
\text { University of } \\
\text { Newcastle Upon Tyne, } \\
\text { UK }\end{array}$ & $\begin{array}{l}\text { Cytochrome P450 } \\
\text { polymorphisms }\end{array}$ & $\begin{array}{l}\text { 1994: } £ 43 \mathrm{k} \\
\text { 1995: } £ 44.4 \mathrm{k} \\
1996: £ 45.6 \mathrm{k}\end{array}$ \\
\hline Dr ND Carter & $\begin{array}{l}\text { St George's Hospital } \\
\text { Medical School, } \\
\text { Department of Child } \\
\text { Health, London, UK }\end{array}$ & $\begin{array}{l}\text { Identification of DNA } \\
\text { polymorphisms in a } \\
\text { hypertensive and } \\
\text { control population } \\
\text { from South London }\end{array}$ & $\begin{array}{l}\text { 1987: } £ 26.5 \mathrm{k} \\
\text { 1988: As '87 } \\
\text { plus inflation } \\
\text { 1989: As '87 } \\
\text { plus inflation } \\
\text { 1990: £36.5k }\end{array}$ \\
\hline $\begin{array}{l}\text { Professor I } \\
\text { Hindmarch }\end{array}$ & $\begin{array}{l}\text { Human Psycho- } \\
\text { pharmacology } \\
\text { Research Unit, } \\
\text { University of Leeds, } \\
\text { UK }\end{array}$ & $\begin{array}{l}\text { Human psycho- } \\
\text { pharmacology of } \\
\text { nicotine }\end{array}$ & $\begin{array}{l}\text { 1988: } £ 56 \mathrm{k} \\
\text { 1989: As '88 } \\
\text { plus inflation } \\
\text { 1990: } £ 61.6 \mathrm{k} \\
\text { 1991: £15k }\end{array}$ \\
\hline $\begin{array}{l}\text { Professor JR } \\
\text { Clamp }\end{array}$ & $\begin{array}{l}\text { University of Bristol, } \\
\text { Department of } \\
\text { Medicine, Bristol } \\
\text { Royal Infirmary, UK }\end{array}$ & $\begin{array}{l}\text { Effect of smoking on } \\
\text { mucosal protection in } \\
\text { the colon }\end{array}$ & $\begin{array}{l}\text { 1987: } £ 15.5 \mathrm{k} \\
\text { 1988: As '87 } \\
\text { plus inflation } \\
\text { 1989: As '87 } \\
\text { plus inflation }\end{array}$ \\
\hline Newsom-Davis & & & $1991: £ 14.3 \mathrm{k}$ \\
\hline $\begin{array}{l}\text { Professor J } \\
\text { Clausen }\end{array}$ & $\begin{array}{l}\text { Roskilde University, } \\
\text { Denmark }\end{array}$ & DNA adducts & $\begin{array}{l}\text { 1990: } £ 22 \mathrm{k} \\
\text { 1991: } 111.7 \mathrm{k} \\
\text { 1992: } 555.9 \mathrm{k} \\
\text { 1993: } £ 34 \mathrm{k}\end{array}$ \\
\hline Dr VJ Knott & $\begin{array}{l}\text { Royal Ottawa Hospital, } \\
\text { Canada }\end{array}$ & $\begin{array}{l}\text { Nicotine and brain } \\
\text { activity }\end{array}$ & $\begin{array}{l}\text { 1990:£68.2k } \\
\text { 1991: NIL } \\
\text { 1992: } 449.2 \mathrm{k} \\
\text { 1993: £54k }\end{array}$ \\
\hline Dr G Currie & $\begin{array}{l}\text { Marie Curie Research } \\
\text { Institute, Oxted, } \\
\text { Surrey, UK }\end{array}$ & p53 and cell cycle & $\begin{array}{l}\text { 1990: } £ 31.9 \mathrm{k} \\
\text { 1991: } 34.8 \mathrm{k} \\
\text { 1992: } 35 \mathrm{k} \\
\text { 1993: } 440 \mathrm{k}\end{array}$ \\
\hline Dr T Jelsma & $\begin{array}{l}\text { Marie Curie Institute, } \\
\text { UK }\end{array}$ & p53 and cell cycle & 1989: $228.8 \mathrm{k}$ \\
\hline $\begin{array}{l}\text { Professor PM } \\
\text { Stell }\end{array}$ & $\begin{array}{l}\text { Department of } \\
\text { Otorhinolaryngology } \\
\text { Royal Liverpool } \\
\text { Hospital }\end{array}$ & $\begin{array}{l}\text { p53 in head and neck } \\
\text { cancer }\end{array}$ & 1991: $£ 15.2 \mathrm{k}$ \\
\hline Dr JK Field & Department of Clinical & p53 in head and neck & $1992^{17}: £ 32.51$ \\
\hline
\end{tabular}

Genomics, Society and Policy, Vol.5, No.1 (2009) ISSN: 1746-5354

(C) ESRC Genomics Network. 


\begin{tabular}{|c|c|c|c|}
\hline & $\begin{array}{l}\text { Dental Sciences, } \\
\text { School of Dentistry, } \\
\text { University of Liverpool }\end{array}$ & $\begin{array}{l}\text { cancer (taken over } \\
\text { from Stell) }\end{array}$ & 1993: £32.5k \\
\hline $\begin{array}{l}\text { Professor VV } \\
\text { Kakkar }\end{array}$ & $\begin{array}{l}\text { Thrombosis Research } \\
\text { Institute, King's } \\
\text { College School of } \\
\text { Medicine, London, UK }\end{array}$ & $\begin{array}{l}\text { Antifunctional and } \\
\text { other reagents against } \\
\text { platelet-derived } \\
\text { growth factor }\end{array}$ & $\begin{array}{l}\text { 1987: } £ 31.6 \mathrm{k} \\
\text { 1988: As '87 } \\
\text { plus inflation. } \\
\text { 1989: As '87 } \\
\text { plus inflation } \\
\text { 1990: £35.2k } \\
\text { 1991: £34.8k }\end{array}$ \\
\hline \multirow[t]{2}{*}{ Dr DN Cooper } & \multirow[t]{2}{*}{$\begin{array}{l}\text { Thrombosis Research } \\
\text { Institute, London }\end{array}$} & $\begin{array}{l}\text { Mutations in } \\
\text { thrombotic disease }\end{array}$ & $\begin{array}{l}\text { 1992: } £ 24.7 \mathrm{k} \\
\text { 1993: } 442.5 \mathrm{k} \\
\text { 1994: } £ 65 \mathrm{k} \\
\text { 1995: £22.5k }\end{array}$ \\
\hline & & $\begin{array}{l}\text { Unstable trinucleotide } \\
\text { repeats/ Factor VII }\end{array}$ & $\begin{array}{l}\text { 1996: £44.4k } \\
\text { 1997: £48k }\end{array}$ \\
\hline $\begin{array}{l}\text { Professor K } \\
\text { Syrjanen }\end{array}$ & $\begin{array}{l}\text { University of Kuopio, } \\
\text { Finland }\end{array}$ & Human papillomavirus & $\begin{array}{l}\text { 1992: £42.6k } \\
\text { 1993: £43k } \\
\text { 1994: £59.4k }\end{array}$ \\
\hline Dr A Springall & Clevedon, UK & Segregation analysis & $\begin{array}{l}\text { 1991: £12.7k } \\
\text { 1992: £30k } \\
\text { 1993: £30k }\end{array}$ \\
\hline \multirow[t]{2}{*}{ Mr PN Lee } & \multirow[t]{2}{*}{$\begin{array}{l}\text { PN Lee Statistics and } \\
\text { Computing Ltd, Sutton, } \\
\text { Surrey, UK }\end{array}$} & $\begin{array}{l}\text { Lifestyle confounders } \\
\text { of ETS exposure }\end{array}$ & $\begin{array}{l}\text { 1992: } £ 31 \mathrm{k} \\
\text { 1993: } £ 35 \mathrm{k} \\
1994: £ 42 \mathrm{k} \\
1995: £ 25 \mathrm{k}\end{array}$ \\
\hline & & $\begin{array}{l}\text { Hungarian Lifestyle } \\
\text { Project }\end{array}$ & $\begin{array}{l}\text { 1994: } £ 30 \mathrm{k} \\
\text { 1995: £76.4k } \\
\text { 1996: £20k }\end{array}$ \\
\hline $\begin{array}{l}\text { Professor MA } \\
\text { Smith }\end{array}$ & $\begin{array}{l}\text { Leeds General } \\
\text { Infirmary, UK }\end{array}$ & Osteoporosis & $\begin{array}{l}\text { 1992: £20k } \\
\text { 1993: } 24 \mathrm{k} \\
\text { 1994: } 22.8 \mathrm{k} \\
\text { 1995: £11k }\end{array}$ \\
\hline Dr P Farmer & $\begin{array}{l}\text { MRC Toxicology Unit, } \\
\text { Leicester, UK }\end{array}$ & $\begin{array}{l}\text { DNA adducts and free } \\
\text { radical damage }\end{array}$ & $\begin{array}{l}\text { 1993: £20k } \\
\text { 1994: £20k } \\
\text { 1995: £20k } \\
\text { 1996: £20k }\end{array}$ \\
\hline \multirow[t]{4}{*}{ Professor J Gray } & \multirow[t]{4}{*}{$\begin{array}{l}\text { Institute of Psychiatry, } \\
\text { London, UK }\end{array}$} & $\begin{array}{l}\text { Effects of nicotine on } \\
\text { attention in } \\
\text { Alzheimers }\end{array}$ & $\begin{array}{l}\text { 1987: £29.5k } \\
\text { 1988: As '87 } \\
\text { plus inflation } \\
\text { 1989: As '87 } \\
\text { plus inflation }\end{array}$ \\
\hline & & & 1990: £9.3k \\
\hline & & $\begin{array}{l}\text { Nicotine, } \\
\text { reinforcement and } \\
\text { cognition }\end{array}$ & $\begin{array}{l}\text { 1991: £37.2k } \\
\text { 1992: £40.9k } \\
\text { 1993: } £ 44 \mathrm{k}\end{array}$ \\
\hline & & $\begin{array}{l}\text { Neuro-degenerative } \\
\text { disease }\end{array}$ & $\begin{array}{l}\text { 1993: £37.5k } \\
\text { 1994: } 175 \mathrm{k} \\
\text { 1995: } £ 40 \mathrm{k}\end{array}$ \\
\hline $\begin{array}{l}\text { Professor H } \\
\text { Poulsen }\end{array}$ & $\begin{array}{l}\text { University of } \\
\text { Copenhagen, Denmark }\end{array}$ & $\begin{array}{l}\text { Oxidative DNA } \\
\text { damage }\end{array}$ & $\begin{array}{l}\text { 1994: £85k } \\
\text { 1995: } 660 \mathrm{k} \\
\text { 1996: } £ 60 \mathrm{k}\end{array}$ \\
\hline
\end{tabular}

Genomics, Society and Policy, Vol.5, No.1 (2009) ISSN: 1746-5354

(C) ESRC Genomics Network. 


\begin{tabular}{|c|c|c|c|}
\hline Dr H Rothschild & $\begin{array}{l}\text { Louisiana State } \\
\text { University Medical } \\
\text { Centre, New Orleans, } \\
\text { USA }\end{array}$ & $\begin{array}{l}\text { Human genetics of } \\
\text { lung cancer }\end{array}$ & $\begin{array}{l}1994: £ 42 \mathrm{k} \\
1995: £ 38 \mathrm{k} \\
1996: £ 38 \mathrm{k}\end{array}$ \\
\hline $\begin{array}{l}\text { Professor D } \\
\text { Barker }\end{array}$ & $\begin{array}{l}\text { MRC Environmental } \\
\text { Epidemiology Unit, } \\
\text { Southampton, UK }\end{array}$ & $\begin{array}{l}\text { Foetal Nutrition and } \\
\text { Disease }\end{array}$ & $\begin{array}{l}\text { 1994: £30k } \\
\text { 1995: } 130 \mathrm{k} \\
\text { 1996: £30k }\end{array}$ \\
\hline Dr E Perry & $\begin{array}{l}\text { MRC Neurochemical } \\
\text { Pathology Unit, } \\
\text { Newcastle Upon Tyne, } \\
\text { UK }\end{array}$ & $\begin{array}{l}\text { Effects of chronic } \\
\text { nicotine in human } \\
\text { brain }\end{array}$ & $\begin{array}{l}\text { 1995: } £ 49 \mathrm{k} \\
\text { 1996: } £ 49 \mathrm{k} \\
\text { 1997: } 449 \mathrm{k}\end{array}$ \\
\hline Dr S Wonnacott & University of Bath, UK & $\begin{array}{l}\text { Nicotinic acetylcholine } \\
\text { receptor plasticity }\end{array}$ & 1995: $£ 51 \mathrm{k}^{18}$ \\
\hline Nelson & & Review of cytokines & 1995: £11k \\
\hline
\end{tabular}

$(*)$ Figures for 1995-1997 are BAT projections based on money committed.

Additional proposals/areas under consideration for 1996/97 but not yet confirmed were: Wonnacott's "Nicotine acetylcholine receptor plasticity" (£51k proposed for 1996);

Feinstein’s "Epidemiology of smoking-related diseases" (£40k proposed for 1997); Salonen’s "Antioxidant supplementation in atherosclerosis prevention" (£40k proposed for 1996 and $£ 40 \mathrm{k}$ for 1997); Kakkar’s "Epidemiological study of heart disease in India" (£30k proposed for 1996 and £30k for 1997), Nelson's "Cytokines and lung disease" (£40k proposed for 1997), Holgate’s "Asthma" (40k proposed for 1997) and Farmer’s "Oxidative damage" (£30k proposed for 1997).

The BAT projects incorporated into the SRG research budget from 1993 were those by Springall, Lee, Smith and Syrjanen ${ }^{19}$.

\footnotetext{
${ }^{1}$ Anon (u ndated), R esearch \& Devel opment: Li st of Sm oking an d Heal th C ontracts. B ates No. 500874413-4415. L. Waters, (u ndated), Details of SR G Con tracts. Bates N o. 500874416-4419. Available from: http://old.ash.org.uk/html/conduct/pdfs/genetics/srg_ctr1.pdf. Access ed: 31 August, 2008.

${ }^{2}$ BAT (undated). Bates No. 500874431. Available from: http://old.ash.org.uk/html/conduct/pdfs/genetics/idle salary.pdf. Accessed: 31 October, 2008.

${ }^{3}$ R.E. Thornton, Scientific Research Group Budget 1990-1991, 27 September 1990. Bates No. 300524524. Available from:

http://old.ash.org.uk/html/conduct/pdfs/genetics/srg bud 9091.pdf. Accessed: Accessed: 31 August, 2008.

${ }^{4}$ R.E. Thornton, Note to Members of the SRG: SRG Budget 1990/1991, 4 December, 1990. Bates No 400313790. Available from: http://old.ash.org.uk/html/conduct/pdfs/genetics/srg 9091 bud.pdf.

Accessed: 31 October, 2008.

${ }^{5}$ SRG, SRG Budget 1991 onwards. Bates No. 510100061. Available from: http://old.ash.org.uk/html/conduct/pdfs/genetics/srg 91budget.pdf. Accessed: 31 October, 2008.

${ }^{6}$ Anon (undated), SRG Budget 1992. Bates No. 510100033. Available from: http://old.ash.org.uk/html/conduct/pdfs/genetics/srg_budget92.pdf. Accessed: 31 October, 2008.

${ }^{7}$ Anon (undated), SRG Budget 1992; BATCO Smoking and Health Budget 1992. Bates No. 300528514-8515. Available from: http://old.ash.org.uk/html/conduct/pdfs/genetics/srg 92_bud.pdf. Accessed: 31 October, 2008.

${ }^{8}$ Anon (undated), SRG Budget 1991/1992. Bates No. 300524700. Available from: http://old.ash.org.uk/html/conduct/pdfs/genetics/srg bud 9192.pdf. Accessed: 31 October, 2008.

${ }^{9}$ BAT, Fax from L Rudge to G.A. Read, SRG Costings, 4 January 1993. Bates No. 400501207-1210. Available from: http://old.ash.org.uk/html/conduct/pdfs/genetics/srg bud 9293.pdf. Accessed: 31 October, 2008.

${ }^{10}$ Anon (undated), Projects - 1993 SRG Work Programme; BATCo Smoking and Health Budget
} 
Projects 1992. Bates No. 300528449-8450. Available from: http://old.ash.org.uk/html/conduct/pdfs/genetics/srg 93 work prog.pdf. Accessed: 31 October, 2008.

${ }^{11}$ Anon (undated), Projected SRG Budget for 1993. Bates No. 510100034. Available from: http://old.ash.org.uk/html/conduct/pdfs/genetics/srg budget93.pdf. Accessed: 31 October, 2008.

${ }^{12}$ SRG, Minutes of the SRG Meeting New York US, 28-30 October, 1993 (first page only - see ref 25 for full minutes). Bates No. 500834102. Anon (undated), SRG Budget 1994. Bates No. 500834110. Available from: http://old.ash.org.uk/html/conduct/pdfs/genetics/srg bud 9394.pdf. Accessed: 31 October, 2008.

${ }^{13}$ BAT, Memo from L. Rudge to C.J.P. de Siqueira et al. Encl. Proposed SRG Budget 1994, 21 December 1993. Bates No. 400500861-0862. Available from: http://old.ash.org.uk/html/conduct/pdfs/genetics/srg_94_ctrs.pdf. Accessed: 31 October, 2008.

${ }^{14}$ Anon (undated), 1994/1995 SRG Budget. Bates No. 403692487. Available from: http://old.ash.org.uk/html/conduct/pdfs/genetics/srg_bud_9495.pdf. Accessed: 31 October, 2008. ${ }^{15}$ BAT, Memo from L. Rudge to SRG Members, 15 February 1995. Bates No. 500833937. Summary of Research Projects Funded by the SRG in 1995. Bates No. 500833942-3947. Available from: http://old.ash.org.uk/html/conduct/pdfs/genetics/srg 95 bud.pdf. Accessed: 31 October, 2008.

${ }^{16}$ Anon (undated), Current Projects (Money Committed)/ Proposals (Areas for Consideration). Bates No. 500834080-4081. Available from: http://old.ash.org.uk/html/conduct/pdfs/genetics/srg_95 bud.pdf. Accessed: 31 October, 2008. ${ }^{17}$ The budgets for this project appear to be incomplete, presumably due to Stell's sudden resignation at the end of 1991. However a total of $£ 65,000$ over two years is recorded as having been paid to Field's project to end 1993, with work actually continuing until April 1994. R.E. Thornton, Note for the Tobacco Strategy Group, 2 December 1993. Bates No. 502520669-0672. Available from: http://old.ash.org.uk/html/conduct/pdfs/genetics/srg_93.pdf Accessed: 31 October, 2008.

${ }^{18}$ BAT states "Paid in '94" but no figure is given. However the total is recorded in S. Wonnacott, (undated), Current Grant Support. Bates No. 50650961-0961. Available from: http://legacy.library.ucsf.edu/tid/try36d00/pdf. Accessed: 31 October, 2008. (Wonnacott applies to the CTR for funds to supplement the project but her application is rejected.)

${ }^{19}$ L. Rudge, SRG Budget 1993. 20 January 1993. Available from: http://old.ash.org.uk/html/conduct/pdfs/genetics/srg cost 93.pdf. Accessed: 31 October, 2008. 


\section{S2: Idle chronology}

\begin{tabular}{|c|c|}
\hline Date & evelopment \\
\hline $\begin{array}{l}17 \text { Sep } \\
1977\end{array}$ & Idle (at St Mary's Hospital) co-authors paper on role of CYP2D6 in debrisoquine metabolism. ${ }^{1}$ \\
\hline Jul 1980 & Idle co-authors abstract suggesting CYP2D6 is linked to the risk of lung cancer in smokers. ${ }^{2}$ \\
\hline Feb 1981 & Idle co-authors paper on debrisoquine metabolism in Nigerian cancer patients. ${ }^{3}$ \\
\hline $\begin{array}{l}11 \text { Jun } \\
1981\end{array}$ & Notes from a talk by Idle in CTR files. ${ }^{4,5}$ (The talk is published in $1982 .{ }^{6}$ ) \\
\hline $\begin{array}{l}8 \mathrm{Nov} \\
1984\end{array}$ & Idle co-authors Nature paper on genetic susceptibility to lung cancer. ${ }^{7}$ \\
\hline 1984 & le joins Lung Cancer Task Force at the US National Cancer Institute (NCI). ${ }^{8}$ \\
\hline $\begin{array}{l}1986-91 \\
\text { (and 1995- } \\
98 \text { ) }\end{array}$ & Idle joins Cancer Research Advancement Board at the Irish Cancer Society. ${ }^{8}$ \\
\hline $\begin{array}{l}1 \text { July } \\
1986\end{array}$ & $\begin{array}{l}\text { Idle joins the CTR's Scientific Advisory Board (SAB) }{ }^{9} \text { He informs CTR in his CV that his } \\
1984 \text { Nature paper "may herald a long-overdue change in the practice of epidemiology" and that } \\
\text { he has established collaboration with the NIH to pursue "the host factors which determine } \\
\text { individual lung cancer risk." }\end{array}$ \\
\hline $\begin{array}{l}3 \mathrm{Mar} \\
1987\end{array}$ & Idle presentation on nicotine metabolism to the SAB. ${ }^{10}$ \\
\hline $\begin{array}{l}21 \text { May } \\
1987\end{array}$ & $\begin{array}{l}\text { "Genetics linked to lung cancer predisposition" press story, with Idle's work endorsed by the } \\
\text { NCI and by Dr Alfred Knudson (another SAB member). }{ }^{11}\end{array}$ \\
\hline $\begin{array}{l}18 \text { Jun } \\
1987\end{array}$ & The CTR board discuss the "recent favorable publicity" relating to Idle and Knudson's work ${ }^{12}$. \\
\hline $\begin{array}{l}11 \mathrm{Dec} \\
1987\end{array}$ & Idle presents his research at the CTR \\
\hline Dec 1987 & $\begin{array}{l}\text { CTR approve a } \$ 47 \mathrm{k} \text { grant to Prof Henry Lynch to collaborate with Idle }{ }^{14} \text {, as part of Lynch's } \\
\text { existing project. }{ }^{15,16,17}\end{array}$ \\
\hline Dec 1987 & $\begin{array}{l}\text { Idle writes a research proposal for the "Establishment of a Laboratory of Cancer } \\
\text { Pharmacogenetics". }\end{array}$ \\
\hline Jan 1988 & $\begin{array}{l}\text { The CTR's PR consultant sends Idle's laboratory proposal to BAT's PR consultant, asking for } \\
\text { the names of UK companies that might back the plan. }{ }^{18}\end{array}$ \\
\hline $\begin{array}{l}5 \mathrm{Feb} \\
1988\end{array}$ & Idle interviewed by BBC about genetic susceptibility to cancer. ${ }^{19}$ \\
\hline $\begin{array}{l}24 \mathrm{Feb} \\
1988\end{array}$ & $\begin{array}{l}\text { SRG Chair informs BAT's Chairman (Patrick Sheehy) that Idle "is Professor elect at a greatly } \\
\text { extended and revamped department of Pharmacology at Newcastle University (where BAT also } \\
\text { has connections) and I anticipate that through the Scientific Research Group we shall be } \\
\text { supporting his work there". }{ }^{20}\end{array}$ \\
\hline $\begin{array}{l}18 \mathrm{Mar} \\
1988\end{array}$ & $\begin{array}{l}\text { Idle sends a copy of an NIH abstract on genetic susceptibility to lung cancer "in confidence" to } \\
\text { BAT. }\end{array}$ \\
\hline $\begin{array}{l}30 \mathrm{Mar} \\
1988\end{array}$ & $\begin{array}{l}\text { BAT meet the molecular biologist Dr Sydney Brenner, who supports the idea of genetic } \\
\text { screening for lung cancer susceptibility. }\end{array}$ \\
\hline $\begin{array}{l}7 \mathrm{Apr} \\
1988\end{array}$ & $\begin{array}{l}\text { BAT write to Idle confirming they will fund his project (referring to a proposal made on } 28 \\
\text { March). }\end{array}$ \\
\hline $\begin{array}{l}18-20 \mathrm{Apr} \\
1988\end{array}$ & The SRG meeting agrees to fund Idle. ${ }^{25}$ \\
\hline $\begin{array}{l}21 \mathrm{Apr} \\
1988\end{array}$ & $\begin{array}{l}\text { BAT's consultant Roe comments on Idle's proposal }{ }^{26} \text { including a note on the historical } \\
\text { background to tobacco industry's interest in genetic susceptibility. }\end{array}$ \\
\hline 1 Jun 1988 & A lunch appointment is made for Idle to meet Sheehy on 25 July. ${ }^{27}$ \\
\hline $\begin{array}{l}23 \text { Jun } \\
1988\end{array}$ & $\begin{array}{l}\text { Idle is a guest in the BAT tent at Wimbledon. }{ }^{28} \text { Other guests include Sir Peter Froggatt, chair of } \\
\text { the Independent Scientific Committee on Smoking and Health. }\end{array}$ \\
\hline $\begin{array}{l}2 \text { Sep } \\
1988\end{array}$ & Idle's research proposal to the SRG: "Molecular Epidemiology of Lung Cancer Risk". ${ }^{29}$ \\
\hline
\end{tabular}




\begin{tabular}{|c|c|}
\hline $\begin{array}{l}29 \text { Sep } \\
1988\end{array}$ & BAT send a five year "research agreement" to the University of Newcastle. ${ }^{30}$ \\
\hline Oct 1988 & Idle becomes Professor of Pharmacogenetics at the University of Newcastle Upon Tyne, UK. ${ }^{31}$ \\
\hline $\begin{array}{l}19 \text { Dec } \\
1988\end{array}$ & Feinstein's review of Idle's BAT proposal severely criticises his epidemiology. ${ }^{32}$ \\
\hline 1988 & $\begin{array}{l}\text { Paper by Roots et al. suggests Idle's proposed association (between debrisoquine metabolism } \\
\text { and lung cancer) is either weak or does not exist. }{ }^{33}\end{array}$ \\
\hline 1989 & Idle is WHO Committee Chairman "Genetic predisposition to toxic effects of chemicals". \\
\hline 1 Jan 1989 & BAT begins funding Idle's project. ${ }^{34}$ \\
\hline $\begin{array}{l}27 \text { Mar } \\
1989\end{array}$ & CTR visits Lynch and express doubts about Idle's part of his project. ${ }^{35}$ \\
\hline Mar 1989 & Daly joins Idle at Newcastle. $^{36}$ \\
\hline $\begin{array}{l}\text { Mar/Apr1 } \\
989\end{array}$ & Idle paper reviewing his previous work on lung cancer susceptibility. ${ }^{37}$ \\
\hline $\begin{array}{l}3 \text { May } \\
1989\end{array}$ & $\begin{array}{l}\text { Glenn (CTR Scientific Director) informs Idle they cannot fund him outside the normal grant } \\
\text { process. }\end{array}$ \\
\hline May 1989 & $\begin{array}{l}\text { Idle co-authors a paper linking genetic predisposition to lung cancer to debrisoquine } \\
\text { metabolism }{ }^{39} \text {. Idle had sent the final manuscript to BAT in January with a note: “.... Nowhere } \\
\text { does it say that smoking causes lung cancer...". } 40\end{array}$ \\
\hline $\begin{array}{l}16 \text { May } \\
1989\end{array}$ & $\begin{array}{l}\text { New York Times article }{ }^{41} \text { predicting that genetic tests for vulnerability to cancer will be } \\
\text { available in } 3 \text { to } 5 \text { years. Quotes NCI researchers saying that genetic tests could help focus anti- } \\
\text { smoking efforts. }\end{array}$ \\
\hline June 1989 & $\begin{array}{l}\text { "VINDICATION" speech by a CTR employee, about the New York Times article and the views } \\
\text { expressed by NC4 }{ }^{2} \text {. Refers to Idle as one CTR researcher working on genetics and lung cancer. }\end{array}$ \\
\hline $\begin{array}{l}\text { July } \\
1989\end{array}$ & $\begin{array}{l}\text { Idle and NCI researchers publish a paper on susceptibility to lung cancer in workers exposed to } \\
\text { occupational carcinogens, which advocates screening and targeting of susceptible individuals. }{ }^{43}\end{array}$ \\
\hline $\begin{array}{l}\text { Jul/Aug } \\
1989\end{array}$ & $\begin{array}{l}\text { Idle and NCI researchers publish a paper re-analysing the data from } 1984 \text { Nature paper and } \\
\text { supporting its conclusions. }{ }^{44}\end{array}$ \\
\hline $\begin{array}{l}2 \text { Aug } \\
1989\end{array}$ & $\begin{array}{l}\text { CTR staff meeting notes that NCI "has indicated interest" in Idle's research and that they have } \\
\text { asked Idle to resubmit his application. }\end{array}$ \\
\hline $\begin{array}{l}4 \text { Oct } \\
1989\end{array}$ & Lynch requests $\$ 24,500$ to extend Idle's part of his CTR project (this is approved) ${ }^{46}$ \\
\hline $\begin{array}{l}31 \text { Oct } \\
1989\end{array}$ & Wall Street Journal article, quoting NCI advocating genetic testing for lung cancer. ${ }^{47}$ \\
\hline $\begin{array}{l}\text { 4 Nov } \\
1989 \\
\end{array}$ & Idle publishes a Lancet commentary advocating his theory. ${ }^{48}$ \\
\hline $\begin{array}{l}30 \mathrm{Nov} \\
1989\end{array}$ & $\begin{array}{l}\text { Idle applies for a CTR grant. }{ }^{49,50} \text { The proposal refers to an attached letter of collaboration from } \\
\text { NCI. }\end{array}$ \\
\hline $\begin{array}{l}20 \text { Dec } \\
1989\end{array}$ & $\begin{array}{l}\text { Idle informs CTR that he has received a letter of collaboration from NCI and seeks an additional } \\
\$ 20,000 \text { for his research with Lynch. }\end{array}$ \\
\hline 4 Jan 1990 & CTR agrees to pay the $\$ 20,000$ requested by Idle. ${ }^{52}$ \\
\hline 5 Jan 1990 & Idle writes to Glenn to thank him $^{53}$ :"We may now be on the road to lay some myths to rest!" \\
\hline $\begin{array}{l}\text { March } \\
1990\end{array}$ & Idle's CTR proposal receives mixed reviews. ${ }^{54}$ \\
\hline $\begin{array}{l}17-20 \\
\text { April } 1990\end{array}$ & Idle's CTR proposal is withdrawn (no reasons given). \\
\hline July 1990 & $\begin{array}{l}\text { Idle and his NCI co-author publish a paper defending the conclusions of their studies }{ }^{58} \text { against } \\
\text { new data that does not support their findings }{ }^{59,60} \text {. No funding acknowledgements. }\end{array}$ \\
\hline $\begin{array}{l}10 \text { July } \\
1990\end{array}$ & $\begin{array}{l}\text { Letter from Idle explaining that his chapter is missing from a recent WHO publication because } \\
\text { the WHO objected to his view that there is "an uncomfortable credibility gap in the widely-held } \\
\text { belief that cigarettes cause lung cancer...". " (Note: an unedited draft of this paper is in Philip } \\
\text { Morris' files, } 21 \text { Sep 1989). }{ }^{62}\end{array}$ \\
\hline $\begin{array}{l}17 \text { July } \\
1990\end{array}$ & SRG visit Idle at Newcastle. ${ }^{63}$ \\
\hline $\begin{array}{l}1 \text { Aug } \\
1990\end{array}$ & $\begin{array}{l}\text { The Journal of the National Cancer Institute (JNCI) publishes two articles on genetic } \\
\text { susceptibility to lung cancer - one by NCI researchers }{ }^{64} \text { and one by Sellers et al (who }\end{array}$ \\
\hline
\end{tabular}




\begin{tabular}{|c|c|}
\hline & $\begin{array}{l}\text { acknowledge CTR funding). }{ }^{65} \text { The editorial }{ }^{66} \text { suggests that the two papers may have identified } \\
\text { the effect of the same gene. } \\
\text { BAT describe the NCI group as "close to" Idle's group. }{ }^{67}\end{array}$ \\
\hline $\begin{array}{l}\text { August } \\
1990\end{array}$ & The JNCI papers gain extensive press coverage. ${ }^{68,69,70}$ \\
\hline $\begin{array}{l}6 \text { Oct } \\
1990\end{array}$ & $\begin{array}{l}\text { Letter from Idle and colleagues to the Lancet about developing tests of variations in the } \\
\text { CYP2D6 gene }{ }^{71} \text {. No tobacco industry funding is acknowledged. }\end{array}$ \\
\hline $\begin{array}{l}15 \text { Oct } \\
1990\end{array}$ & $\begin{array}{l}\text { Letter to Idle from Stephanie London (University of California School of Medicine) agreeing to } \\
\text { collaborate and send DNA samples. }{ }^{72}\end{array}$ \\
\hline $\begin{array}{l}18 \text { Oct } \\
1990\end{array}$ & Idle writes to CTR seeking an additional $£ 29,500(\$ 57,741)$ to begin work with London. ${ }^{73}$ \\
\hline $\begin{array}{l}30 \text { Oct } \\
1990\end{array}$ & CTR approves a supplemental grant of $\$ 57,741$ to Idle via Lynch. $^{74}$ \\
\hline $\begin{array}{l}26 \mathrm{Nov} \\
1990\end{array}$ & $\begin{array}{l}\text { Idle and Daly re-apply for a CTR research grant to include collaborations with London in Los } \\
\text { Angeles and Dr Anne-Lise Børrensen in Norway. }{ }^{75}\end{array}$ \\
\hline Jan 1991 & $\begin{array}{l}\text { The authors of the } 1990 \mathrm{JNCI} \text { papers are criticised for implying that genetics rather than } \\
\text { smoking determines when lung cancer develops. }\end{array}$ \\
\hline $\begin{array}{l}\text { 4 Mar } \\
1991\end{array}$ & $\begin{array}{l}\text { Idle and Daly's progress report to BAT, }{ }^{77} \text { enclosing a paper submitted to Molecular } \\
\text { Pharmacology. }\end{array}$ \\
\hline Apr 1991 & $\begin{array}{l}\text { Idle publishes a review of genetic susceptibility to cancer which criticises IARC for } \\
\text { emphasising the role of tobacco in lung cancer and omitting the genetic constitution of the } \\
\text { population }^{78} \text {. No acknowledgement of tobacco-industry funding. }\end{array}$ \\
\hline Apr 1991 & $\begin{array}{l}\text { Idle and Daly's project "Pharmacogenetic Epidemiology of Lung Cancer" is considered at the } \\
\text { CTR's SAB meeting and funded as requested. }\end{array}$ \\
\hline 1 Jul 1991 & $\begin{array}{l}\text { Idle and Daly’s CTR project begins. They receive } \$ 96,538 \text { in year } 1, \$ 100,000 \text { in year } 2 \text { and } \\
\$ 99,959 \text { in year } 3 .^{80}\end{array}$ \\
\hline $\begin{array}{l}8 \text { Aug } \\
1991 \\
\end{array}$ & $\begin{array}{l}\text { Letter from Daly to BAT seeking travel funds and saying the manuscript sent to them in March } \\
\text { will now be published in the new journal Pharmacogenetics. }{ }^{81}\end{array}$ \\
\hline Oct 1991 & $\begin{array}{l}\text { The first edition of Pharmacogenetics is published. Idle is a founding editor and Editor-in-Chief } \\
\text { (until October 1998) }{ }^{82,83} \text {. It includes the Daly et al. paper, }{ }^{84} \text { which acknowledges part funding } \\
\text { from BAT. }\end{array}$ \\
\hline $\begin{array}{l}15 \text { Oct } \\
1991\end{array}$ & $\begin{array}{l}\text { Idle resigns from the CTR's SAB following a dispute about expenses. }{ }^{85,86} \mathrm{He} \text { continues to } \\
\text { receive project funding. }\end{array}$ \\
\hline Nov 1991 & $\begin{array}{l}\text { Idle co-authors a paper in Pharmacogenetics, finding a low frequency of 'poor metabolisers' in } \\
\text { Turkey }{ }^{88} \text { No funding acknowledgements. }\end{array}$ \\
\hline $\begin{array}{l}4 \mathrm{Dec} \\
1991\end{array}$ & $\begin{array}{l}\text { Idle and Daly's renewal application for the second year of their CTR grant. }{ }^{89} \text { Informs the CTR } \\
\text { that their Norway study does not support Idle's earlier findings. }\end{array}$ \\
\hline 1991 & Two further papers cast doubt on Idle's findings..$^{90,9}$ \\
\hline 1992 & Daly and Idle's progress report to BAT for $1991 .^{92}$ \\
\hline $\begin{array}{l}25 \text { April } \\
1992\end{array}$ & $\begin{array}{l}\text { Idle and Daly co-author a paper on genetic variations in CYP2D6 in patients with Parkinson's } \\
\text { disease. }{ }^{93} \text { Acknowledges part funding from BAT. }\end{array}$ \\
\hline $\begin{array}{l}\text { 5-7 May } \\
1992\end{array}$ & $\begin{array}{l}\text { BAT's SRG minutes note the large number and complexity of metabolising enzymes and state: } \\
\text { "it appears unlikely that a specific relative risk for individuals can be calculated". }{ }^{44}\end{array}$ \\
\hline $\begin{array}{l}30 \mathrm{Nov} \\
1992\end{array}$ & $\begin{array}{l}\text { Idle and Daly's renewal application for the third year of their CTR grant }{ }^{95} \text {. Reports that the } \\
\text { Norwegian part of their study has found no link between CYP2D6 polymorphisms and lung } \\
\text { cancer, but argues there may have been recruitment problems which will not arise in the larger } \\
\text { Los Angeles study. }\end{array}$ \\
\hline Nov 1992 & $\begin{array}{l}\text { New results from NCI researchers report only a weak association between CYP2D6 and lung } \\
\text { cancer. }{ }^{96}\end{array}$ \\
\hline Dec 1992 & $\begin{array}{l}\text { Idle and } 18 \text { of his Newcastle colleagues publish a review of genetic susceptibilities to cancer in } \\
\text { Pharmacogenetics }{ }^{97} \text { They criticise a recent study (Wolf } \text { et al., } 1992^{98} \text { ) that found no link } \\
\text { between CYP2D6 and lung cancer risk. Funding acknowledgements include BAT, the CTR and } \\
\text { the STRC. }\end{array}$ \\
\hline 1993 & $\begin{array}{l}\text { Idle becomes Chief Executive of Genotype Ltd }{ }^{99} \text { as well as head of department and head of the } \\
\text { School of Clinical Medical Science at Newcastle. He has raised } £ 2 \text { million in outside funding } \\
\text { for the Pharmacogenetics Unit since } 1988 \text {. }\end{array}$ \\
\hline
\end{tabular}




\begin{tabular}{|c|c|}
\hline $\begin{array}{l}\text { Feb/ } \\
\text { Mar } 1993\end{array}$ & $\begin{array}{l}\text { Daly, Idle and review genetic variations in metabolism, claiming that the majority of studies are } \\
\text { confirming Idle's findings. }{ }^{100} \text { Funding from BAT, the CTR and the STRC is acknowledged. }\end{array}$ \\
\hline $\begin{array}{l}\text { 7-9 Jun } \\
1993\end{array}$ & $\begin{array}{l}\text { The SRG reports that Idle and Daly are awaiting the results of the LA study; developing genetic } \\
\text { tests for GSTM1 and CYP2E1 and have made a new research proposal. }{ }^{101}\end{array}$ \\
\hline Jul 1993 & $\begin{array}{l}\text { Daly and Idle co-author a short paper identifying another genetic variation in CYP2D6 }{ }^{102} \text {. BAT } \\
\text { and CTR funding is acknowledged. }\end{array}$ \\
\hline Aug 1993 & $\begin{array}{l}\text { Daly and Idle co-author a paper on the GSTM1 gene and bladder cancer. }{ }^{103} \text { Funding from BAT } \\
\text { and the CTR is acknowledged. }\end{array}$ \\
\hline Aug 1993 & $\begin{array}{l}\text { Idle and Daly's revised application to BAT }{ }^{104} \text { (includes CYP1A2, CYP2A6, CYP2D6, } \\
\text { CYP2E1). Visit from SRG Chair (Thornton) to Idle and Daly. }{ }^{105}\end{array}$ \\
\hline Oct 1993 & $\begin{array}{l}\text { Idle, Daly and Newcastle co-workers publish a review of genetic susceptibility to cancer, stating } \\
\text { CYP2D6, CYP1A1 and GSTM are recognised candidate genes and that data are beginning to } \\
\text { emerge on CYP1A2 and CYP2E1 }{ }^{106} \text {. Acknowledges BAT and CTR. }\end{array}$ \\
\hline $\begin{array}{l}20 \text { Oct } \\
1993\end{array}$ & $\begin{array}{l}\text { BAT agrees to fund the "Interindividual variation in nitrosamine metabolism" project, with } \\
\text { Daly as lead investigator, from } 1 \text { January } 1994 \text { to } 31 \text { December } 1996 .{ }^{107}\end{array}$ \\
\hline $\begin{array}{l}28-30 \text { Oct } \\
1993\end{array}$ & $\begin{array}{l}\text { SRG meeting. }{ }^{108} \text { Notes that trying to identify whether some smokers who develop lung cancer } \\
\text { are "genetically susceptible" is one of the original aims of tobacco industry research and is still } \\
\text { being supported. }\end{array}$ \\
\hline $\begin{array}{l}30 \mathrm{Nov} \\
1993\end{array}$ & $\begin{array}{l}\text { Idle and Daly apply to CTR for a further three years' of funding }{ }^{109,110} \text {, enclosing two letters of } \\
\text { collaboration. }{ }^{11,112}\end{array}$ \\
\hline Jan 1994 & $\begin{array}{l}\text { Idle co-authors another review of genetic variations and drug metabolism, which also states that } \\
\text { CYP2D6 has been shown to be associated with cancer risk. }\end{array}$ \\
\hline 1 Jan 1994 & $\begin{array}{l}\text { Idle co-authors a letter to the Lancet on the link between genetic variations in CYP2D6 and } \\
\text { nicotine metabolism. }{ }^{114} \text { Acknowledges funding from the STRC. }\end{array}$ \\
\hline Apr 1994 & $\begin{array}{l}\text { Idle, Daly and others at Newcastle publish a paper in Pharmacogenetics with their Norwegian } \\
\text { collaborators, reporting no significant link between genetic variations in CYP2D6 and lung } \\
\text { cancer. }{ }^{115} \text { Acknowledges CTR funding. }\end{array}$ \\
\hline Apr 1994 & $\begin{array}{l}\text { Idle, Daly and colleagues at Newcastle publish another paper in Pharmacogenetics investigating } \\
\text { whether newly discovered CYP2D6 mutations could explain discrepancies between genetic test } \\
\text { results and debrisoquine metabolism. }{ }^{116} \text { Acknowledges BAT funding. }\end{array}$ \\
\hline Apr 1994 & $\begin{array}{l}\text { Wolf et al.'s response to Idle } \text { et al.'s } 1992 \text { review is published in Pharmacogenetics (it was } \\
\text { submitted in Jan 1993). }{ }^{117} \text { They express concerns that Idle's article is “factually misleading" } \\
\text { and that his "strong opinions... are preventing proper, scientifically correct analysis of the } \\
\text { available data". Idle and others respond (no tobacco funding is acknowledged). }{ }^{118}\end{array}$ \\
\hline $\begin{array}{l}25 \mathrm{Apr} \\
1994\end{array}$ & CTR refuses Idle funding for his proposed further project. ${ }^{119}$ \\
\hline Jun 1994 & $\begin{array}{l}\text { Idle and Daly co-author a paper in Pharmacogenetics }{ }^{120} \text { reporting on the frequency of 'poor } \\
\text { metabolisers' in Jordan. BAT funding acknowledged. }\end{array}$ \\
\hline 7 Jul 1994 & Idle and Daly's final report to BAT. ${ }^{121}$ \\
\hline Nov 1994 & Daly, Idle co-author a review of metabolism genes and disease susceptibility. ${ }^{122}$ \\
\hline Mar 1995 & $\begin{array}{l}\text { Daly, Idle, London and others publish a new mutation in the CYP2D6 gene. }{ }^{123} \text { Acknowledges } \\
\text { funding from BAT and the CTR. }\end{array}$ \\
\hline Aug 1995 & $\begin{array}{l}\text { Idle and Daly co-author a paper in Pharmacogenetics, discussing how to improve the accuracy } \\
\text { of CYP2D6 genetic testing. }{ }^{124} \text { BAT funding acknowledged. }\end{array}$ \\
\hline Aug 1995 & $\begin{array}{l}\text { Idle and Daly co-author a paper in Pharmacogenetics on CYP2D6 and NNK activation (which } \\
\text { concludes that this is not important) }{ }^{125} \text {. No funding acknowledgements. }\end{array}$ \\
\hline Aug 1995 & $\begin{array}{l}\text { London, Daly and Idle investigate lung cancer risk and genetic variations in GSTM1. }{ }^{126} \text { They } \\
\text { find no link with lung cancer risk overall, but suggest there might be a link for lighter smokers. } \\
\text { CTR funding is acknowledged. }\end{array}$ \\
\hline $\begin{array}{l}16 \text { Jun } \\
1995\end{array}$ & $\begin{array}{l}\text { Idle and Gonzalez (co-editor of Pharmacogenetics) named as inventors on a US patent for } \\
\text { CYP2C9 and CYP2A6 test kits (granted on } 6 \text { April 1999). }{ }^{127} \text { The description claims that } \\
\text { CYP2A6 is linked to lung cancer risk. }\end{array}$ \\
\hline Sep 1995 & $\begin{array}{l}\text { Idle co-authors a paper on genetic variations in CYP2A6 and suggests it is linked to both cancer } \\
\text { susceptibility and nicotine metabolism. }{ }^{28}\end{array}$ \\
\hline Nov 1995 & $\begin{array}{l}\text { Daly publishes a paper reviewing drug metabolism, which admits that links between CYP2D6 } \\
\text { and lung cancer are controversial. }\end{array}$ \\
\hline
\end{tabular}




\begin{tabular}{|c|c|}
\hline Late 1995 & $\begin{array}{l}\text { Smith et al. }{ }^{130} \text { publish a review of genetic variability and cancer susceptibility. They conclude } \\
\text { that the role of CYP2D6 remains unclear and that the original strong associations have not been } \\
\text { confirmed. }\end{array}$ \\
\hline Dec 1995 & $\begin{array}{l}\text { London, Idle and Daly co-author a paper which reports that CYP1A1 does not appear to affect } \\
\text { lung cancer risk }{ }^{131} \text {. No tobacco industry funding is acknowledged. }\end{array}$ \\
\hline Dec 1995 & Idle co-authors a paper which advocates genetic screening for drug metabolism. ${ }^{132}$ \\
\hline Dec 1995 & $\begin{array}{l}\text { NCI researchers (in Pharmacogenetics) consider possible explanations for some studies finding } \\
\text { no link between lung cancer risk and CYP2D }{ }^{133} \text {. Includes Fisher's hypothesis as one possible } \\
\text { explanation. }\end{array}$ \\
\hline $\begin{array}{l}15 \mathrm{Dec} \\
1995\end{array}$ & Idle moves to the Norwegian University of Science and Technology in Trondheim. \\
\hline 1 Jan 1996 & BAT begins payments for Daly's project on CYP1A2 and CYP2E1. ${ }^{134}$ \\
\hline Apr 1996 & $\begin{array}{l}\text { London, Daly and Idle co-author a paper finding no link between CYP2E1 and lung cancer } \\
\text { risk. }{ }^{135} \text { Support from CTR acknowledged. }\end{array}$ \\
\hline Jun 1996 & $\begin{array}{l}\text { Idle (now at Trondheim) and co-workers at Newcastle publish a paper in Pharmacogenetics on } \\
\text { CYP2D6 and smoking status, finding no link. }{ }^{136} \text { Support from the STRC is acknowledged. }\end{array}$ \\
\hline $\begin{array}{l}19 \text { Aug } \\
1996\end{array}$ & $\begin{array}{l}\text { Idle and Daly co-author a paper describing an improved genetic test for CYP2D6. No tobacco } \\
\text { funding acknowledged. }{ }^{137}\end{array}$ \\
\hline Aug 1996 & $\begin{array}{l}\text { Daly and Idle co-author a paper reporting improved detection of some genetic variations in } \\
\text { CYP2D6 (in Pharmacogenetics). }{ }^{138} \text { Acknowledges support from BAT and the CTR. }\end{array}$ \\
\hline Sep 1996 & $\begin{array}{l}\text { Daly, Idle and others review the methods of detection of mutations in CYP2D6. }{ }^{139} \text { No funding } \\
\text { acknowledgements. }\end{array}$ \\
\hline Dec 1996 & $\begin{array}{l}\text { London, Idle and Daly co-author a paper in Pharmacogenetics, finding no link between } \\
\text { CYP2C9 and lung cancer risk. }{ }^{140} \text { CTR acknowledged. }\end{array}$ \\
\hline Jan 1997 & $\begin{array}{l}\text { A meta-analysis of studies on CYP2D6 and lung cancer susceptibility is published. }{ }^{141} \text { finding } \\
\text { no association and concluding that "the quality of the studies left much to be desired". }\end{array}$ \\
\hline Apr 1997 & $\begin{array}{l}\text { Idle and Daly are co-authors on a paper finding two new variants in CYP2D6. }{ }^{142} \text { (published in } \\
\text { Pharmacogenetics). No tobacco funding acknowledged. }\end{array}$ \\
\hline Jun 1997 & $\begin{array}{l}\text { London, Daly, Idle and co-workers publish a paper on the CYP2D6 Los Angeles study. }{ }^{143} \\
\text { Concludes that polymorphisms in CYP2D6 are not a strong risk factor for lung cancer. } \\
\text { Acknowledges CTR. }\end{array}$ \\
\hline Sep 1997 & Idle co-authors a paper on CYP2A6 metabolism. ${ }^{144}$ No funding acknowledgements. \\
\hline Oct 1997 & $\begin{array}{l}\text { Idle and former colleagues at Newcastle publish a paper in Pharmacogenetics on smoking } \\
\text { behaviour and CYP2D6 genotype, concluding that it may influence 'dependence'. }{ }^{145} \\
\text { Acknowledges STRC. }\end{array}$ \\
\hline Oct 1997 & $\begin{array}{l}\text { London, Daly, Idle co-author a paper in Pharmacogenetics on lung cancer risk and CYP2C9. }{ }^{146} \\
\text { They find no link. No tobacco funding acknowledged. }\end{array}$ \\
\hline Feb 1998 & $\begin{array}{l}\text { A paper by a French team finding no association between CYP2D6 and lung cancer } \\
\text { susceptibility is published in Pharmacogenetic. }{ }^{147}\end{array}$ \\
\hline Mar 1998 & $\begin{array}{l}\text { NCI researchers conclude that CYP2D6 is not a marker for lung cancer risk but "the concept } \\
\text { that genetic polymorphisms may contribute to differential cancer risk is sound". } 148\end{array}$ \\
\hline Apr 1998 & $\begin{array}{l}\text { Cholerton and co-workers at Newcastle publish a paper on the lack of association between a } \\
\text { genetic variation in the DRD2 gene and cigarette smoking. }{ }^{149} \text { They acknowledge part funding } \\
\text { by BAT. }\end{array}$ \\
\hline Jun 1998 & $\begin{array}{l}\text { A meta-analysis of studies on CYP2D6 is published in Pharmacogenetics by a team at Sheffield } \\
\text { University. }{ }^{150} \text { They conclude that there may be a small difference in risk but "it is hard to } \\
\text { justify further studies". }\end{array}$ \\
\hline Jul 1998 & $\begin{array}{l}\text { Idle co-authors a paper on CYP2A6 metabolism }{ }^{151} \text {. Acknowledges support from Rothmans } \\
\text { International Services Ltd and the United States Tobacco Company Ltd. }\end{array}$ \\
\hline Dec 1998 & $\begin{array}{l}\text { Idle, London, Daly co-author a paper in Pharmacogenetics, on the CYP2D6 Los Angeles } \\
\text { study. }{ }^{152} \text { It attempts to find a better correlation by including some rarer mutations (but does not } \\
\text { succeed). Part funding from the CTR acknowledged. }\end{array}$ \\
\hline Dec 1998 & $\begin{array}{l}\text { Daly and co-authors publish a paper on genetic variations in CYP2E1 (they find none of } \\
\text { functional significance). }{ }^{153} \text { They acknowledge BAT funding. }\end{array}$ \\
\hline Dec 1998 & $\begin{array}{l}\text { Daly co-authors a paper which concludes that CYP2D6 studies have not been confirmed but } \\
\text { that CYP1A1 and CYP2E1 are of possible functional significance. }\end{array}$ \\
\hline
\end{tabular}




\begin{tabular}{|l|l|}
\hline $\begin{array}{l}\text { 13 Mar } \\
1999\end{array}$ & $\begin{array}{l}\text { London (now at the US National Institute of Environmental Health), Idle, Daly and a co-author } \\
\text { publish a paper in the Lancet on CYP2A6. } \\
\text { or smoking habits. No tobacco funding acknowledged. }\end{array}$ \\
\hline $\begin{array}{l}\text { 12 Jun } \\
\text { 1999 }\end{array}$ & $\begin{array}{l}\text { Idle (now based in the Czech Republic) letter to the } \text { Lancet saying he differs with his co-authors } \\
\text { on the paper. }\end{array}$ \\
\hline Mar 2000 & $\begin{array}{l}\text { A meta-analysis of studies of genetic variations in CYP1A1 and lung cancer risk is published in } \\
\text { Pharmacogenetics, finding no link. }{ }^{156}\end{array}$ \\
\hline Jun 2002 & $\begin{array}{l}\text { Idle is a co-author on a paper finding that debrisoquine metabolism is influenced by CYP1A1 as } \\
\text { well as CYP2D6 and proposing this as the reason for the discrepancies between studies. } \\
\text { Acknowledges a travel grant for Idle from the STRC. }\end{array}$ \\
\hline
\end{tabular}

${ }^{1}$ A. Mahgoub, J.R. Idle, LG. Dring, R. Lancaster and R.C. Smith, Polymorphic hydroxylation of debrisoquine in man, Lancet 1977: ii, 584-586.

${ }^{2}$ M.R. Hetzel, M. Law, E.E. Keal, T.P. Sloan, J.R. Idle and R.L. Smith, Is there a genetic component in bronchial carcinoma in smokers?, Thorax 1980: 35, 709.

${ }^{3}$ J.R. Idle, A. Mahgoub, T.P. Sloan, R.L. Smith, C.O. Mbanefo and E.A. Bababunmi, Some observations on the oxidation phenotype status of Nigerian patients presenting with cancer, Cancer Letter, 1981: 11 (4), 331-338.

${ }^{4}$ Anon(1981), Handwritten Notes, 11 June 1981. Bates No: ZN5611-5612. Available from: http://legacy.library.ucsf.edu/tid/pws1aa00/pdf. Accessed: 31 October, 2008.

${ }^{5}$ H. Zahn, Memo to WT Hoyt from: the IARC Symposium from: Host Factors in Human Carcinogenesis, Cape Sounion, Greece, June 8-11, 1981. Bates no. 10404748-4772. Available from: http://legacy.library.ucsf.edu/tid/gdc4aa00/pdf. Accessed: 31 October, 2008.

${ }^{6}$ J.C. Ritchie and J.R. Idle, Population studies of polymorphism in drug oxidation and its relevance to carcinogenesis, IARC Scientific Publication, 1982: 39, 381-394.

${ }^{7}$ R. Ayesh, J.R. Idle, J.C. Ritchie, M.J. Crothers and M.R. Hetzel, Metabolic oxidation phenotypes as markers for susceptibility to lung cancer, Nature, 1984: 311, 169-170.

${ }^{8}$ J.R. Idle, Curriculum Vitae, July 1986. Bates No. 60074945-4970. Available from:

http://tobaccodocuments.org/ctr/CTRMN011057-1082.html. Accessed: 31 October, 2008.

${ }^{9}$ CTR, Scientific Advisory Board Members 1954-, 8 April 1995. Bates No. 60032100-2100. Available from: http://legacy.library.ucsf.edu/tid/mzu20a00/pdf. Accessed: 31 October, 2008.

${ }^{10}$ CTR, Memo from Sheldon C. Sommers, 12 February, 1987. Bates No. 60033765. Available from: http://legacy.library.ucsf.edu/tid/nhw20a00.

${ }^{11}$ R. Cooke, Genetics linked to lung cancer predisposition, The Record, 21 May, 1987. Council for Tobacco Research. Bates No. 11302575-2576. Available from: http://legacy.library.ucsf.edu/tid/bvy5aa00. Accessed: 31 October, 2008.

${ }^{12}$ CTR, Minutes of the meeting of the Board of Directors, June 18, 1987. Bates No. 11067571. Available from: http://tobaccodocuments.org/ctr/CTRMIN-BD000200-0229.html Accessed: 31 October, 2008.

${ }^{13}$ CTR, Minutes of the Eighteenth Annual Meeting of Members, December 11, 1987. Bates no. 11067274-7284. Available from: http://tobaccodocuments.org/ctr/CTRMIN-MOM000245-0255.html. Accessed: 31 October, 2008.

${ }^{14}$ D. Ford, Memo to the committee comprising Drs Brennan and Sommers, re Henry T. Lynch, M.D., Creighton University, Omaha, NB $1^{\text {st }}$ Renewal Application No. 1297CR1 "A Case/Control Study of Breast and Lung Cancer with the addendum of the Debrisoquine Study", 25 May 1988, Bates No. 50316790-6790. Available from: http://legacy.library.ucsf.edu/tid/xoe00d00/pdf. Accessed: 31 October, 2008.

${ }^{15}$ H.T. Lynch, Letter to Sheldon Sommers, 17 November 1987. Bates No. 50316850-6850. Available from: http://legacy.library.ucsf.edu/tid/qoe00d00/pdf. Accessed: 31 October, 2008.

${ }^{16}$ H.T. Lynch, Letter to Sheldon Sommers, 10 December 1987. Bates No. 50316848-6848. Available from: http://legacy.library.ucsf.edu/tid/ooe00d00/pdf. Accessed: 31 October, 2008.

${ }_{17}^{17}$ J.F. Glenn, Letter to Henry Lynch, 5 January, 1988 (CTR Grant No 1291). Bates No. 503168456846. Available from: http://legacy.library.ucsf.edu/tid/moe00d00/pdf. 
${ }^{18}$ L.S. Zahn, Letter to Alan Campbell-Johnson, 14 January, 1988 (and enclosure). Bates No. 4010557744-5799. Available from: http://old.ash.org.uk/html/conduct/pdfs/genetics/zahnlet.pdf. Accessed: 31 October, 2008.

${ }^{19}$ BBC, World in Action [Transcript], 5 February, 1988. Bates No. 60032199-2202. Available from: http://legacy.library.ucsf.edu/tid/qbv20a00/pdf. Accessed: 31 October, 2008.

${ }^{20}$ R.E. Thornton, Note for Mr P. Sheehy, Chairman, BAT Industries, 24 February, 1988. Bates No. 401055766. Available from: http://old.ash.org.uk/html/conduct/pdfs/genetics/sheehy.pdf. Accessed: 31 October, 2008.

${ }^{21}$ J.R. Idle [Letter to Ray Thornton, BATCo]. 18 Mar 1988. British American Tobacco. Bates No. 401055755/5756. Available from: http://www.old.ash.org.uk/html/conduct/pdfs/genetics/idle_let.pdf. Accessed: 31 October, 2008.

${ }^{22}$ N. Caporaso, R. Hoover, S. Aisner, J. Resau, B. Trump, H. Issaq, G. Muschik and C.C. Harris, Debrisoquine metabolic phenotype and the risk of lung cancer [Abstract]. Proceedings of the $24^{\text {th }}$ Annual Meeting of the American Society of Clinical from:cology; 1988 May 22-24; New Orleans, USA.

${ }^{23}$ British American Tobacco. [Note from: a Meeting with Dr Sydney Brenner, Windsor House, $30^{\text {th }}$ March, 1988]. 1988. British American Tobacco. Bates No. 401055736/5737. Available from: http://old.ash.org.uk/html/conduct/pdfs/genetics/brenner.pdf. Accessed: 31 October, 2008.

${ }^{24}$ R.E. Thornton [Letter to Dr JR Idle]. 7 Apr 1988. British American Tobacco. Bates No. 401055748/5748. Available from: http://old.ash.org.uk/html/conduct/pdfs/genetics/idle_grant.pdf. Accessed: 31 October, 2008.

${ }^{25}$ British American Tobacco. [Minutes of the Scientific Research Group Meeting - London, April 1820, 1988]. 1988. British American Tobacco. Bates No. 400313819-3821. Available from: http://old.ash.org.uk/html/conduct/pdfs/genetics/srg_mtg88.pdf. Accessed: 31 October, 2008.

${ }^{26}$ F.J.C. Roe, [Comments from: Grant Proposal from Jeffrey Idle, St. Mary’s Hospital Medical School and University of Newcastle upon Tyne]. 21 April, 1988. British American Tobacco. Bates No. 401055716/5718. Available from: http://old.ash.org.uk/html/conduct/pdfs/genetics/roe.pdf. Accessed: 31 October, 2008.

${ }^{27}$ R.E. Thornton, Breathe North Appeal, 1 June, 1988. Bates No. 401055695. Available from: http://old.ash.org.uk/html/conduct/pdfs/genetics/appeal.pdf. Accessed: 31 October, 2008.

${ }^{28}$ R.E. Thornton, Note to Mr R.A. Crichton. Guests for Wimbledon - Thursday 23rd June. 20 June, 1988. Bates No. 300530044. Available from: http://legacy.library.ucsf.edu/tid/tpv97a99

${ }^{29}$ J.R. Idle, Research Proposal, 2 September, 1988. Bates No. 401055536-5540. Available from: http://old.ash.org.uk/html/conduct/pdfs/genetics/idle_lc_prop.pdf Accessed: 31 October, 2008.

${ }^{30}$ N.B. Cannar, Letter to Department of Pharmacological Sciences: For the Attention of Professor J.R. Idle. 29 September, 1988. Bates No. 401055682-5684. Available from:

http://legacy.library.ucsf.edu/tid/ime11a99/pdf Accessed: 31 October, 2008.

${ }^{31}$ J.R. Idle, Biographical sketch, 26 November, 1990. Bates no. 50308886-8887. Available from: http://legacy.library.ucsf.edu/tid/cpa00d00/pdf. Accessed: 31 October, 2008.

${ }^{32}$ A.R. Feinstein, Letter to R.E. Thornton, 19 December, 1988. Bates No. 401055643-5646. http://old.ash.org.uk/html/conduct/pdfs/genetics/feinstein_review.pdf. Accessed: 31 October, 2008.

${ }^{33}$ I. Roots, N. Drakoulis, M. Ploch, G. Heinemeyer, R. Loddenkemper, T. Minks, M. Nitz, F. Otte and M. Koch, Debrisoquine hydroxylation phenotype, acetylation phenotype and ABO blood groups as genetic host factors of lung cancer risk, Klin Wochenschr, 1988: 66, 87-97.

${ }^{34}$ L. Waters, (undated), Research \& Development: List of smoking and health contracts. BATCo Document. Bates No. 500874413-4419. Available from:

http://old.ash.org.uk/html/conduct/pdfs/genetics/srg_ctr1.pdf. Accessed: 31 October, 2008.

${ }_{35}$ D.H. Ford, [Memorandum to Dr J.F. Glenn and Staff, Re: Site visit with Dr Henry Lynch and Staff, Creighten University School of Medicine, Omaha, NE]. 27 March, 1989. Council for Tobacco Research. Bates No. 60037005/7006. Available from: http://legacy.library.ucsf.edu/tid/rjz20a00. Accessed: 31 October, 2008.

${ }^{36}$ A.K. Daly, Biography, 26 November, 1990. Bates No. 50308888-8889. Available from:

http://legacy.library.ucsf.edu/tid/zza00d00/pdf. Accessed: 31 October, 2008.

${ }^{37}$ J.R. Idle, Cytochrome P450IID phenotypes and human cancer risk, Cancer Detection and Prevention, 1989: 14(2), 275-280.

${ }^{38}$ J.F. Glenn, Letter to Jeffrey Idle, 3 May, 1989. Bates No. 11320956. Available from: 
http://legacy.library.ucsf.edu/tid/bhm6aa00/pdf. Accessed: 31 October, 2008.

${ }^{39}$ M. Law, M.R. Hetzel, J.R. Idle, Debrisoquine metabolism and genetic predisposition to lung cancer, British Journal of Cancer, 1989: 59, 686-687.

${ }^{40}$ J.R. Idle. [Handwritten note to R.E Thornton]. 30 January, 1989. British American Tobacco. Bates No. 401055600/5600. Available from:

http://old.ash.org.uk/html/conduct/pdfs/genetics/prepub note.pdf. Accessed: 31 October, 2008.

${ }^{41}$ G. Kolata, "Scientists pinpoint genetic changes that predict cancer," New York Times, 16 May, 1989. Available from: http://www.nytimes.com/1989/05/16/science/scientists-pinpoint-genetic-changes-thatpredict-cancer.html.

${ }^{42}$ Anon. [Speech]. Undated. Council for Tobacco Research. Bates No. 60035145/5151. Available from: http://legacy.library.ucsf.edu/tid/mmx20a00. Accessed: 31 October, 2008.

${ }^{43}$ N. Caporaso, R.B. Hayes, M. Dosemeci, R. Hoover, R. Ayesh, M. Hetzel and J. Idle, Lung cancer risk, occupational exposure, and the debrisoquine metabolic ohenotype, Cancer Research, 1989: 49, 3675-3679.

${ }^{44}$ N. Caporaso, L.W. Pickle, S. Bale, R. Ayesh, M. Hetzel and J. Idle, The distribution of debrisoquine metabolic phenotypes and implications for the suggested association with lung cancer risk, Genetic Epidemiology, 1989: 6, 517-524.

${ }^{45}$ Council for Tobacco Research [Minutes of Staff Meeting, 2 August, 1989], 1989. Bates No. 60034608-4609. Available from: http://legacy.library.ucsf.edu/tid/kxw20a00. Accessed: 31 October, 2008.

${ }^{46}$ CTR, Confidential Report Scientific Advisory Board Meeting, 17-20 April, 1990. Bates No.

CTRMIN-SAB000818-083. Available from: http://legacy.library.ucsf.edu/tid/bnx30a00/pdf. Accessed: 31 October, 2008.

${ }^{47}$ M. Waldholz, Zeroing in; A genetic discovery helps predict who will get cancer, Wall Street Journal, 31 October, 1989. http://legacy.library.ucsf.edu/tid/uty5aa00.

${ }^{48}$ J.R. Idle, Poor metabolisers of debrisquine reveal their true colours, Lancet, 1989: 2(8671), 1097.

${ }^{49}$ CTR, Application for research grant(2811), 30 November, 1989. Bates No. 50556680-6693. Available from: http://legacy.library.ucsf.edu/tid/pzk36d00/pdf. Accessed: 31 October, 2008.

${ }^{50}$ J.R. Idle, Letter to Glenn, 30 November, 1989. Bates No. 50556678-6679. Available from: http://legacy.library.ucsf.edu/tid/ozk36d00/pdf. Accessed: 31 October, 2008.

${ }_{51}^{5}$ J.R. Idle, [Letter to James F Glenn] 20 December, 1989. Council for Tobacco Research. Bates No. 50316730/6731. Available from: http://legacy.library.ucsf.edu/tid/ope00d00. Accessed: 31 October, 2008.

${ }_{52}$ R.F. Gertenbach, Letter to Dr Henry T. Lynch, Re: Grant No. 1297CR2, 4 January, 1990. Bates No. 60040508. Available from: http://legacy.library.ucsf.edu/tid/occ30a00/pdf. Accessed: 31 October, 2008.

${ }^{53}$ J.R. Idle, Letter to Glenn, 5 January, 1990. Bates no. 50556658. Available from: http://legacy.library.ucsf.edu/tid/mal36d00/pdf. Accessed: 31 October, 2008.

${ }^{54}$ A. Knudson, Review of grant application no. 2811, 19 March, 1990. Bates No. 50556665-6666. Available from: www.ctr-usa.org.

${ }^{55}$ R.K. Boutwell, Review of grant application no. 2811, 11 March, 1990. Bates No. 50556663-6664. Available from: www.ctr-usa.org.

${ }^{56}$ D.W. Nebert, Letter to David Stone, CTR, 1 February, 1990. Bates no. 50556673-6674. Available from: http://legacy.library.ucsf.edu/tid/kzk36d00/pdf. Accessed: 31 October, 2008.

${ }^{57}$ G.B. Pierce, Review of grant application no. 2811, 14 March, 1990. Bates No. 50556660-6662. Available from: www.ctr-usa.org.

${ }^{58}$ N. Caporaso and J.R. Idle, The rationale for case-control methodology in epidemiological studies of cancer risk (Response to Speirs et al, 1990), British Journal of Clinical Pharmacology, 1990: 30(1), 149-150.

${ }^{59}$ C.J. Spiers, S. Murray, D.S. Davies, A.F. Biolamabadeje and A.R. Boobis, Debrisoquine oxidation phenotype and susceptibility to lung cancer, British Journal of Clinical Pharmacology, 1990: 29, 101109.

${ }^{60}$ A.R. Boobis and D.S.Davis, Debrisoquine oxidation phenotype and susceptibility to lung cancer. $\mathrm{Br}$ J Clin Pharmacol 1990; 30: 653-656.

${ }^{61}$ J.R. Idle, Letter to 'Colleague', 10 July, 1990. Bates No. 60032218-2219. Available from: http://tobaccodocuments.org/ctr/60032218-2218.html ; http://tobaccodocuments.org/ctr/60032219- 
2219.html. Accessed: 31 October, 2008.

${ }^{62}$ J.R. Idle, Tobacco, host polymorphism and occupation as cooperative risk factors in human cancers, Unedited draft, 21 September, 1989. Bates No. 2015003518-3536. Available from:

http://legacy.library.ucsf.edu/tid/qgc44e00/pdf. Accessed: 31 October, 2008.

${ }^{63}$ R.E. Thornton, Visit to Department of Pharmacogenetics at Newcastle, 17 July, 1990. Bates No. 300506627. Available from: http://legacy.library.ucsf.edu/tid/skc08a99/pdf. Accessed: 31 October, 2008.

${ }^{64}$ N.E. Caporaso, M.A. Tucker, R.N. Hoover et al, Lung cancer and the debrisoquine metabolic phenotype, Journal of the National Cancer Institute, 1990: 82, 1264-1272.

${ }^{65}$ T.A. Sellers, J.E. Bailey-Wilson, R.C. Elston, et al, Evidence for Mendelian inheritance in the pathogenesis of lung cancer, Journal of the National Cancer Institute, 1990: 82, 1272-1279.

${ }^{66}$ G.E. Bonney, Interactions of genes, environment and life-style in lung cancer development, Journal of the National Cancer Institute, 1990: 82, 1236-1238.

${ }^{67}$ R.E. Thornton [Note For Mr B.D. Bramley: Genetic predisposition to lung cancer], 12 September, 1990. British American Tobacco. Bates No: 300506580/6580. Available from: http://old.ash.org.uk/html/conduct/pdfs/genetics/1990papers_note.pdf. Accessed: 31 October, 2008. ${ }^{68} \mathrm{~J}$. Foreman, Researchers say heredity plays a key role in lung cancer, The Boston Globe, 1 August, 1990. Available from: http://legacy.library.ucsf.edu/tid/hfq39e00

${ }^{69}$ M. Waldholz, Lung cancer risk linked to heredity, Wall Street Journal, 1 August, 1990. Available from: http://legacy.library.ucsf.edu/tid/jgr31a00

${ }^{70}$ M. Gladwell, Gene linked to lung cancer, The Washington Post, 2 August, 1990.

${ }^{71}$ A.K. Daly, M. Armstrong and J.R. Idle, Molecular genotyping to predict debrisoquine hydroxylation phenotype, The Lancet, 1990: 336, 889-890.

${ }^{72}$ S. London, Letter to Jeffrey Idle, 15 October, 1990. Bates no. 60032226. Available from: http://legacy.library.ucsf.edu/tid/hcv20a00/pdf. Accessed: 31 October, 2008.

${ }_{73}^{73}$ J.R. Idle, Letter to Glenn, 18 October, 1990. Bates No. 50316712. Available from: www.ctr-usa.org.

${ }^{74}$ R.F. Gertenbach, Letter to Dr Henry T. Lynch, Re: Grant no. 1297D, 30 October, 1990. Bates No. 60040554. Available from: http://legacy.library.ucsf.edu/tid/bec30a00/pdf. Accessed: 31 October, 2008.

${ }^{75}$ CTR, Application for research grant (3119), 26 November, 1990. Bates No. 50308873-8879. Available from: http://legacy.library.ucsf.edu/tid/bpa00d00/pdf. Accessed: 31 October, 2008.

${ }^{76}$ A.E. Reif, Heredity as a determining factor in which smokers die of lung cancer, Journal of the National Cancer Institute, 1991: 83(1), 64.

${ }^{77}$ A.K. Daly, M. Armstrong and J.R. Idle, Report to BAT regarding progress and future experiments for the year ending December 1990, 4 March, 1991. Bates No. 300506496-6497. Available from: http://old.ash.org.uk/html/conduct/pdfs/genetics/daly_pharmacogenetics.pdf. Accessed: 31 October, 2008.

${ }^{78}$ J.R. Idle, Is environmental carcinogenesis modulated by host polymorphism?, Mutation Research, 1991: 247(2), 259-266.

${ }^{79}$ J.F. Glenn, Letter to Idle, 25 April, 1991. Bates No. 50308857. Available from:

http://legacy.library.ucsf.edu/tid/wpa00d00/pdf. Accessed: 31 October, 2008.

${ }^{80}$ CTR (undated), Funding history summary, Jeffrey R Idle, SAB-rated grant no: 3119. Bates No. 60035400. Available from: http://legacy.library.ucsf.edu/tid/qvx20a00/pdf. Accessed: 31 October, 2008.

${ }^{81}$ A.K. Daly, Letter to R.E. Thornton, 8 August, 1991. Bates No. 300506429. Available from: http://old.ash.org.uk/html/conduct/pdfs/genetics/daly pharmacogenetics.pdf. Accessed: 31 October, 2008.

82 J. Idle, and F. Gonzalez, Editorial, Pharmacogenetics, 1991: 1, 1.

${ }^{83}$ Pharmacogenetics, 8(5), inside cover, October 1998.

${ }^{84}$ A.K. Daly, M. Armstrong, S.C. Monkman, M.E. Idle and J.R.Idle, Genetic and metabolic criteria for the assignment of debrisoquine 4-hydroxylation (cytochrome P4502D6) phenotypes,

Pharmacogenetics, 1991: 1, 33-41.

${ }^{85}$ J.R. Idle, Letter to Dr Jim F. Glenn, 11 October, 1991. Bates No. 11303524-11303525. Available from: http://legacy.library.ucsf.edu/tid/daa6aa00.

${ }^{86}$ J.R. Idle, Letter to Dr Jim F. Glenn, 15 October, 1991. Bates No. 11303519. Available from: http://legacy.library.ucsf.edu/tid/daa6aa00/pdf. Accessed: 31 October, 2008. 
${ }^{87}$ CTR, Memo from James F. Glenn to chairman and members of the Scientific Advisory Board, 14 November, 1991. Bates No. 60031869. Available from: http://legacy.library.ucsf.edu/tid/euu20a00/pdf. Accessed: 31 October, 2008.

${ }^{88}$ S. Sardas, J. Pontin and J. R. Idle, Polymorphic 4-hydroxylation of debrisoquine in a Turkish population, Pharmacogenetics 1991: 1(2), 123-124.

${ }^{89}$ CTR, Non-competitive renewal grant application (3119R1), 4 December, 1991. Bates No. 50388328840. Available from: www.ctr-usa.org.

${ }^{90}$ J. Benítez, J.M. Ladero, C. Jura, J.A. Carrillo, J. Cobaleda, A. Llerena, E. Vargas and J.J. Muñoz, Polymorphic oxidation of debrisoquine in lung cancer patients. Eur J Cancer 1991: 27(2): 158-161.

${ }^{91}$ J-C. Duche, C. Joanne, J. Barre, H. de Cremoux, J.C. Dalphin, A. DePierre, P. Brochard, J.P.

Tillement and P. Bechtel, Lack of a relationship between the polymorphism of debrisoquine oxidation and lung cancer. Br J Clin Pharmacol 1991: 31: 533-536.

${ }_{92}$ A.K. Daly, M. Armstrong and J.R. Idle (undated), Progress report to British-American Tobacco Co Ltd for the year 1991. Bates No. 300503341-300503356. Available from: http://legacy.library.ucsf.edu/tid/ijf08a99/pdf. Accessed: 31 October, 2008.

${ }^{93}$ M. Armstrong, A.K. Daly, S. Cholerton, D.N. Bateman and J.R. Idle, Mutant debrisoquine hydroxylation genes in Parkinson's Disease, The Lancet 1992: 339, 1017-1018.

${ }^{94}$ L.J. Rudge and R.E. Thornton, Minutes of the SRG meeting, Viking Inn, Montreal, Canada, 5-7 May, 1992. Bates No. 400501290-1297. Available from:

http://old.ash.org.uk/html/conduct/pdfs/genetics/srg_92.pdf. Accessed: 31 October, 2008.

${ }^{95}$ CTR, Non-competitive renewal grant application (3119R2), 30 November, 1992. Bates No. 50308810-8815. Available from: http://legacy.library.ucsf.edu/tid/gqa00d00/pdf. Accessed: 31 October, 2008.

${ }^{96}$ N.E. Caporaso, P.G. Shields, M.T. Landi, G.L. Shaw, M.A. Tucker, R. Hoover, H. Sugimura, A. Weston and C.C. Harris, The debrisoquine metabolic phenotype and DNA-based assays: Implications of misclassification for the association of lung cancer and the debrisoquine metabolic phenotype, Environmental Health Perspectives 1992: 98, 101-105.

${ }^{97}$ J.R. Idle, M. Armstrong, A.V. Boddy, C. Boustead, S. Cholerton, J. Cooper, A.K. Daly, J. Ellis, W. Gregory, H. Hadidi, C. Höfer, J. Holt, J. Leathart, N. McCraken, S.C. Monkman, J.E. Painter, H. Taber, D. Walker and M. Yule, The pharmacogenetics of chemical carcinogenesis, Pharmacogenetics 1992: 2, 246-258.

${ }^{98}$ C.R. Wolf, C.A.D. Smith, A.C. Gough, J.E. Moss, K.A. Vallis, G. Howard, F.J. Carey, K. Mills, W. McNee, J. Carmichael and N.K. Spurr, Relationship between the debrisoquine hydroxylase polymorphism and cancer susceptibility, Carcinogenesis 1992: 13, 1035-1038.

${ }_{99}$ J.R. Idle, Resumé, 30 November, 1993. Bates No. 50462761-2763. Available from: http://legacy.library.ucsf.edu/tid/kaw09d00/pdf. Accessed: 31 October, 2008.

${ }_{100}$ A.K. Daly, S. Cholerton, W. Gregory and J.R. Idle, Metabolic polymorphisms, Pharmac. Ther., 1993: 57, 129-160.

${ }^{101}$ SRG, Minutes of the SRG meeting, Copenhagen, Denmark, 7-9 June, 1993. Bates No. 5664012591266. Available from: http://old.ash.org.uk/html/conduct/pdfs/genetics/srg_mins 93 june.pdf. Accessed: 31 October, 2008.

${ }^{102}$ M. Armstrong, J.R. Idle and A.K. Daly, A polymorphic CfoI site in exon 6 of the human cytochrome P450 CYP2D6 gene detected by the polymerase chain reaction, Human Genetics 1993: 91,616-617.

${ }^{103}$ A.K. Daly, D.J. Thomas, J. Cooper, W.R. Pearson, D.E. Neal and J.R. Idle, Homozygous deletion of gene for glutathione S-transferase M1 in bladder cancer, British Medical Journal 1993: 307(6902), 481-482.

${ }^{104}$ J.R. Idle and A.K. Daly, Application to British-American Tobacco Co Ltd, Project title: Interindividual variation in nitrosamine metabolism, August 1993. Bates No. 500807188-07195. Available from: http://old.ash.org.uk/html/conduct/pdfs/genetics/nitrosamines.pdf. Accessed: 31 October, 2008.

${ }^{105}$ R.E. Thornton, Memo to Boyse, Read and Rudge, 6 September, 1993. Bates No. 400501038-1041. Available from: http://old.ash.org.uk/html/conduct/pdfs/genetics/barker_idle notes.pdf. Accessed: 31 October, 2008.

${ }^{106}$ J.R. Idle and A.K.Daly, New opportunities in cancer risk evaluation using PCR-based DNA analysis for CYP2D6, Environmental Health Perspectives 1993: 101 Suppl 3, 117-120. 
${ }^{107}$ S. Yena, Letter to Daly, 20 October, 1993. Bates No. 500807313. Available from: http://old.ash.org.uk/html/conduct/pdfs/genetics/nitrosamines.pdf. Accessed: 31 October, 2008.

${ }^{108}$ SRG, Minutes of the SRG meeting, New York, US, 28-30 October, 1993. Available from: http://old.ash.org.uk/html/conduct/pdfs/genetics/srg mins 93 oct.pdf. Accessed: 31 October, 2008.

${ }_{109}$ J.R. Idle, Renewal application, Pharmacogenetic epidemiology of lung cancer, 30 November, 1993. Bates No. 50462744-2755. Available from: http://legacy.library.ucsf.edu/tid/gaw09d00/pdf. Accessed: 31 October, 2008.

${ }^{110}$ J.R. Idle, Letter from Idle to Dr Harmon C. McAllister (CTR Scientific Director), 30 November, 1993. Bates no. 50462735. Available from: http://legacy.library.ucsf.edu/tid/zzv09d00/pdf. Accessed: 31 October, 2008.

${ }^{111}$ F.J. Gonzalez, Letter to Daly, 26 November, 1993. Bates No. 50462756. Available from: http://legacy.library.ucsf.edu/tid/haw09d00/pdf. Accessed: 31 October, 2008.

${ }^{112}$ S. London, Letter to Daly, 18 November, 1993. Bates No. 50462758. Available from: http://legacy.library.ucsf.edu/tid/mhw09d00/pdf. Accessed: 31 October, 2008.

${ }^{113}$ F.J. Gonzalez and J.R. Idle, Pharmacogenetic phenotyping and genotyping. Present status and future potential, Clinical Pharmacokinetic Concepts 1994: 26(1), 59-70.

${ }^{114}$ S. Cholerton, A. Arpanahi, N. McCraken, C. Boustead, H. Taber, E. Johnstone, J. Leathert, A.K.

Daly and J.R. Idle, Poor metabolisers of nicotine and CYP2D6 polymorphism, The Lancet 1994: 343, 62-63.

${ }^{115}$ T. Tefre, A.K. Daly, M. Armstrong, J.B. Leathart, J.R. Idle, A. Brogger and A.L. Borresen, Genotyping of the CYP2D6 gene in Norwegian lung cancer patients and controls, Pharmacogenetics 1994: 4(2), 47-57.

${ }^{116}$ M. Armstrong, K. Fairbrother, J.R. Idle and A.K.Daly, The cytochrome P450 CYP2D6 allelic variant CYP2D6J and related polymorphisms in a European population, Pharmacogenetics 1994: 4, 73-81.

${ }^{117}$ C.R. Wolf, C.A.D. Smith, T. Bishop, D. Forman, A.C. Gough and N.K. Spurr, CYP2D6 genotyping and the association with lung cancer susceptibility, Pharmacogenetics 1994: 4, 104-106.

${ }^{118}$ S.J. London, A.K. DalyD.C. Thomas, N.E. Caporaso and J.R. Idle, Methodological issues in the interpretation of studies of the CYP2D6 genotype in relation to lung cancer risk, Pharmacogenetics 1994: 4, 107-108.

${ }^{119}$ CTR, Letter from Glenn to Idle, 25 April, 1994. Bates No. 50462733. Available from: http://legacy.library.ucsf.edu/tid/xzv09d00/pdf. Accessed: 31 October, 2008.

${ }^{120}$ H.F. Hadidi, S. Cholerton, S.C. Monkman, M. Armstrong, Y.M. Irshaid, N.M. Rawashdeh, A.K. Daly and J.R. Idle, Debrisoquine 4-hydroxylation (CYP2D6) polymorphism in Jordanians, Pharmacogenetics 1994: 4(3), 159-161.

${ }^{121}$ A.K. Daly and J.R. Idle, 'Identification of genetic mutations which modulate chemical toxicity and evaluation of novel strategies for population screening', Final report to British-American Tobacco Co Ltd. 1994. Bates No. 50021987-21999. Daly, Letter to Rudge, 7 July, 1994. Bates No. 500807036. Available from: http://old.ash.org.uk/html/conduct/pdfs/genetics/daly report.pdf. Accessed: 31 October, 2008.

${ }^{122}$ A.K. Daly, S. Cholerton, M. Armstrong and J.R. Idle, Genotyping for polymorphisms in xenobiotic metabolism as a predictor of disease susceptibility, Environmental Health Perspectives 1994: 102 Suppl 9, 55-61.

${ }_{123}$ A.K. Daly, J.B.S. Lethart and S.J. London, An inactive cytochrome P450 CYP2D6 allele containing a deletion and a base substitution, Human Genetics 1995: 95, 337-341.

${ }^{124}$ V.M. Steen, O.A. Andreassen, A.K. Daly, T. Tefre, A.L. Borresen, J.R. Idle and A.K. Gulbrandsen, Detection of the poor metabolizer-associated CYP2D6(D) gene deletion allele by long-PCR technology, Pharmacogenetics 1995: 5(4), 215-223.

${ }^{125}$ C.L. Crespi, D.T. Steimel, B.W. Penman, K.R. Korzekwa, P. Fernandez-Salguero, J.T. Buters, H.V. Gelboin, F.J. Gonzalez, J.R. Idle and A.K. Daly, Comparison of substrate metabolism by wild type CYP2D6 protein and a variant containing methionine, not valine, at position 374, Pharmacogenetics 1995: 5(4), 234-243.

${ }^{126}$ S.J. London, A.K. Daly, J. Cooper, W.C. Navidi, C.L. Carpenter and J.R. Idle, Polymorphism of gluthathione S-transferase M1 and lung cancer risk among African-Americans and Caucasians in Los Angeles County, California, Journal of the National Cancer Institute 1995: 87(16), 1246-1253.

${ }^{127}$ United States Patent, 1999, Patent no. US5891633, "Defects in Drug Metabolism". 
${ }^{128}$ P. Fernandez-Salguero, S.M. Hoffman, S. Cholerton, H. Mohrenweiser, H. Raunio, A. Rautio, O. Pelkonen, J.D. Huang, W.E. Evans, J.R. Idle and F.J. Gonzalez, A genetic polymorphism in coumarin 7-hydroxylation: Sequence of the human CYP2A genes and identificantion of variant CYP2A6 alleles, American Journal of Human Genetics 1995: 57(3), 651-660.

${ }^{129}$ A.K. Daly, Molecular basis of polymorphic drug metabolism, Journal of Molecular Medicine 1995: 73, 539-553.

${ }^{130}$ G. Smith, L.A. Stanley, E. Sim, R.C. Strange and C.R. Wolf, Metabolic polymorphisms and cancer susceptibility, Cancer Surveys 1995: 25, 27-65.

${ }^{131}$ S.J. London, A.K. Daly, K.S. Fairbrother, C. Holmes, C.L. Carpenter, W.C. Navidi and J.R. Idle, Lung cancer risk in African-Americans in relation to a race-specific CYP1A1 polymorphism, Cancer Research 1995: 55(24), 6035-6037.

${ }^{132}$ J.R. Idle and R.L. Smith, Pharmacogenetics in the new patterns of healthcare delivery, Pharmacogenetics 1995: 5(6), 347-350.

${ }^{133}$ N. Caporaso, M.R. DeBaun and N. Rothman, Lung cancer and CYP2D6 (the debrisoquine polymorphism): Sources of heterogeneity in the proposed association, Pharmacogenetics 1995: 5, S129-S134.

${ }^{134}$ L. Rudge, BATCo memo to SRG members, 15 February, 1995. Bates No. 500833937-3947. Available from: http://old.ash.org.uk/html/conduct/pdfs/genetics/srg 95.pdf. Accessed: 31 October, 2008.

${ }^{135}$ S.J. London, A.K. Daly, J. Cooper, C.L. Carpenter,W.C. Navidi, L. Ding and J.R. Idle, Lung cancer risk in relation to the CYP2E1 Rsa I genetic polymorphism among African-Americans and Caucasians in Los Angeles County, Pharmacogenetics 1996: 6(2), 151-158.

${ }^{136}$ S. Cholerton, C. Boustead, H. Taber, A. Arpanahi and J.R. Idle, CYP2D6 genotypes in cigarette smokers and non-tobacco users, Pharmacogenetics 1996: 6, 261-263.

${ }^{137}$ R. Løvlie, A.K. Daly,A. Molven, J.R. Idle and V.M. Steen, Ultrarapid metabolisers of debrisoquine: Characterization and PCR-based detection of alleles with duplication of the CYP2D6 gene, FEBS Letters 1996: 392(1), 30-34.

${ }^{138}$ A.K. Daly, K.S. Fairbrother, O.A. Andreassen, S.J. London, J.R. Idle and V.M. Steen, Characterization and PCR-based detection of two different hybrid CYP2D7P/CYP2D6 alleles associated with the poor metabolizer phenotype, Pharmacogenetics 1996: 6(4), 319-328.

${ }^{139}$ A.K. Daly, V.M. Steen, K.S. Fairbrother and J.R. Idle, CYP2D6 multiallelism, Methods Enzymol 1996: 272, 199-210.

${ }^{140}$ S.J. London, A.K. Daly, J.B. Leathart, W.C. Navidi and J.R. Idle, Lung cancer risk in relation to the CYP2C9*1/CYP2C9*2 genetic polymorphism among African-Americans and Caucasians in Los Angeles County, California, Pharmacogenetics 1996: 6(6), 527-533.

${ }^{141}$ P.M. Christensen, P.C. Gøtzsche and K. Brøsen, The sparteine/debrisoquine (CYP2D6) oxidation polymorphism and the risk of lung cancer: A meta analysis, European Journal of Clinical Pharmacology 1997: 51, 389-393.

${ }^{142}$ R. Løvlie, A.K. Daly, J.R. Idle and V.M. Steen, Characterization of the $16+9 \mathrm{~kb}$ and $30+9 \mathrm{~kb}$ CYP2D6 XbaI haplotypes, Pharmacogenetics 1997: 7(2), 149-152.

${ }^{143}$ S.J. London, A.K. Daly, J.B.S. Leathart W.C. Navidi, C.C. Carpenter and J. R. Idle, Genetic polymorphism of CYP2D6 and lung cancer risk in African-Americans and Caucasians in Los Angeles County, Carcinogenesis 1997: 18, 1203-1214.

${ }^{144}$ H. Hadidi, K. Zahlsen, J.R. Idle and S. Cholerton, A single amino acid substitution (Leu160His) in cytochrome P450 CYP2A6 causes switching from 7-hydroxylation to 3-hydroxylation of coumarin, Food Chem Toxicol 1997: 35(9), 903-907.

${ }^{145}$ C. Boustead, H. Taber, J.R. Idle and S. Cholerton, CYP2D6 genotype and smoking behaviour in cigarette smokers, Pharmacogenetics 1997: 7, 411-414.

${ }^{146}$ S.J. London, T. Sullivan-Klose, A.K. Daly and J.R. Idle, Lung cancer risk in relation to the CYP2C9 genetic polymorphism among Caucasians in Los Angeles County, Pharmacogenetics 1997: 7, 401-404.

${ }^{147}$ M. Legrand-Andréoletti, I. Stücker, D. Marez, P. Galais, J. Cosme, N. Sabbagh, C. Spire, S. Cenée, J.J. Lafitte, P. Beaune and F. Broly, Cytochrome P450 CYP2D6 gene polymorphism and lung cancer susceptibility in Caucasians, Pharmacogenetics 1998: 8, 7-14.

${ }^{148}$ G.L. Shaw, R.T. Falk, J.N. Frame, B. Weiffenbach, J.C. Nesbitt, H.I. Pass, N.E. Caporaso, D.T. Moir and M.A. Tucker, Genetic polymorphism of CYP2D6 and lung cancer risk, Cancer Epidemiology, Biomarkers and Prevention 1998: 7, 215-219. 
${ }^{149}$ A.B. Singleton, J.H. Thomson, C.M. Morris, J.A. Court, S. Lloyd and S. Cholerton, Lack of association between the dopamine D2 receptor gene allele DRD2*A1 and cigarette smoking in a United Kingdom population, Pharmacogenetics 1998: 8, 125-128.

${ }^{150}$ A. Rostami-Hodjegan, M.S. Lennard, H.F. Woods and G.T. Tucker, Meta-analysis of studies of the CYP2D6 polymorphism in relation to lung cancer and Parkinson's Disease, Pharmacogenetics 1998: 8, 227-238.

${ }^{151}$ H. Hadidi, Y. Irshaid, C.B. Vagbo, A. Brunsvik, S. Cholerton, K. Zahlsen and J.R. Idle, Variability of coumarin 7- and 3-hydroxylation in a Jordanian population is suggestive of a functional polymorphism in cytochrome P450 CYP2A6, Eur J Clin Pharmacol 1998: 54(5), 437-441.

152 J.B.S. Leathart, S.J. London, A. Steward, J.D. Adams, J.R. Idle and A.K. Daly, CYP2D6 phenotype - genotype relationships in African-Americans and Caucasians in Los Angeles, Pharmacogenetics 1998: 8, 529-541.

${ }^{153}$ K.S. Fairbrother, J. Grove, I. de Waziers, D.T. Steimel, C.P. Day, C.L. Crespi and A.K. Daly, Detection and characterization of novel polymorphisms in the CYP2E1 gene, Pharmacogenetics 1998: 8, 543-552.

${ }^{154}$ A.K. Daly, K.S. Fairbrother, and J. Smart, Recent advances in understanding the molecular basis of polymorphisms in genes encoding cytochrome P450 enzymes, Toxicol Lett 1998: 102-103, 143-147.

${ }_{155}$ S.J. London, J.R. Idle, A.K. Daly and G.A. Coetzee, Genetic variation of CYP2A6, smoking, and risk of cancer, Lancet 1999: 353, 898-899.

${ }^{156}$ R.S. Houlston, CYP1A1 polymorphisms and lung cancer risk: A meta-analysis, Pharmacogenetics 2000: 10, 105-114.

${ }^{157}$ C.P. Granvil, K.W. Krausz, H.V. Gelboin. J.R. Idle and F.J. Gonzalez, 4-hydroxylation of debrisoquine by human CYP1A1 and its inhibition by quinidine and quinine, The Journal of Pharmacology and Experimental Therapeutics 2002: 301, 1025-1032. 


\section{S3: Rothschild chronology}

\begin{tabular}{|c|c|}
\hline $1977-1981$ & Rothschild funded for CTR "Special Project 91". ${ }^{1,2}$ Total funding: $\$ 121,821 .^{3}$ \\
\hline Feb 1982 & $\begin{array}{l}\text { CTR lawyers recommend a further } \$ 25,000 \text { for Rothschild to look at "genetic aspects of lung } \\
\text { cancer". }\end{array}$ \\
\hline Mar 1982 & $\begin{array}{l}\text { Rothschild gives evidence for the tobacco industry at the Waxman hearings, arguing that } \\
\text { genetics may determine who gets lung cancer. }\end{array}$ \\
\hline Apr 1982 & Rothschild's funding for CTR "Special Project \#118" is approved. ${ }^{6}$ \\
\hline 7 Jun 1983 & Rothschild receives approval for a further $\$ 34,359$ to extend CTR Special Project $\# 118 .{ }^{7}$ \\
\hline Feb 1986 & $\begin{array}{l}\text { Rothschild co-authors a paper claiming to support the existence of " } a \text { susceptibility gene to } \\
\text { lung cancer" }{ }^{8} \text { No funding acknowledgments. }\end{array}$ \\
\hline 28 Aug 1986 & CTR approves $\$ 48,764$ further funding for Rothschild's "Special Project \#138". ${ }^{9}$ \\
\hline Oct 1986 & Correction to Feb 1986 paper published. ${ }^{10}$ \\
\hline 1 Aug 1987 & $\begin{array}{l}\text { Rothschild co-authors another paper claiming to support the hypothesis of genetic } \\
\text { susceptibility to lung cancer. }{ }^{11} \text { Funding acknowledgments do not include the CTR. }\end{array}$ \\
\hline 12 Jan 1988 & CTR approves another $\$ 52,582$ for Rothschild's "Special Project No. 138-A". ${ }^{12}$ \\
\hline $\begin{array}{l}\text { Nov/Dec } \\
1988\end{array}$ & $\begin{array}{l}\text { Rothschild co-authors another paper suggesting lung cancer susceptibility may also increase } \\
\text { risk of other cancers. }{ }^{13} \text { CTR not included in funding acknowledgements. }\end{array}$ \\
\hline Aug 1990 & $\begin{array}{l}\text { Rothschild is a co-author on the JNCI paper Sellers et al.(1990), which gains extensive press } \\
\text { coverage for supposedly identifying a genetic factor in lung cancer [see Idle chronology]. }\end{array}$ \\
\hline 1991 & $\begin{array}{l}\text { BAT begin funding Springall to reproduce Sellers } \text { et al.'s results. Springall receives } £ 72,700 \\
\text { over three years. }\end{array}$ \\
\hline 1 Jan 1992 & $\begin{array}{l}\text { Rothschild co-authors a paper which finds that family history of lung cancer does not appear } \\
\text { to differ with cancer type. }{ }^{14} \text { Part funding from CTR acknowledged. }\end{array}$ \\
\hline 1 May 1992 & $\begin{array}{l}\text { Rothschild co-authors a further paper on evidence for an interaction between smoking and } \\
\text { genetic predisposition to lung cancer. }{ }^{15} \text { No funding acknowledgements. }\end{array}$ \\
\hline 5-7 May 1992 & $\begin{array}{l}\text { The SRG minutes note that Springall and Lee have purchased Rothschild's dataset (for } \\
£ 25,000^{16} \text { ) but are having difficulty reproducing Sellers et al. and "are concerned his model } \\
\text { may be the wrong one.". }{ }^{7}\end{array}$ \\
\hline Jul/Aug 1992 & $\begin{array}{l}\text { Rothschild is a co-author on another paper suggesting that "the genetic component of lung } \\
\text { cancer may be greater than previously estimated", although the paper concludes that it is } \\
\text { premature to suggest genetic screening. }{ }^{18} \text { No funding acknowledgements. }\end{array}$ \\
\hline April 1993 & $\begin{array}{l}\text { Rothschild is a co-author on another paper which claims to provide evidence that a genetic } \\
\text { factor may affect the risk of lung cancer. }{ }^{19} \text { Part funding from the CTR is acknowledged. }\end{array}$ \\
\hline 7-9 June 1993 & $\begin{array}{l}\text { The SRG reports that Springall has successfully reproduced Sellers } \text { et al. and that a proposal } \\
\text { has been submitted from the Sellers group to the SRG. }\end{array}$ \\
\hline Oct 1993 & $\begin{array}{l}\text { Rothschild's colleague JE Bailey-Wilson presents their proposal. }{ }^{21} \text { Rothschild's project then } \\
\text { listed as a new project approved, under the name of another colleague: R Elston. }{ }^{22}\end{array}$ \\
\hline Jan 1994 & $\begin{array}{l}\text { SRG begin funding Rothschild and colleagues for a 3-year project on the genetics of lung } \\
\text { cancer "pending funding by the NIH" ( } £ 118,000 \text { in total). }\end{array}$ \\
\hline Sept 1994 & $\begin{array}{l}\text { Rothschild co-authors another paper on genetic susceptibility to "smoking-associated } \\
\text { cancers". }{ }^{24} \text { No tobacco funding acknowledged. }\end{array}$ \\
\hline 2000 & $\begin{array}{l}\text { Rothschild receives } 3 \text { grants (total } \$ 660,000 \text { ) from the NIH to study genetic susceptibility to } \\
\text { lung cancer. }{ }^{25}\end{array}$ \\
\hline
\end{tabular}

\footnotetext{
${ }^{1}$ W.T. Hoyt, Letter to Henry Rothschild, 22 April, 1977. Bates No. 11014713. CTR SP-FILES 014694.

Available from: http://legacy.library.ucsf.edu/tid/xzv09d00/pdf. Accessed: 31 October, 2008.

${ }^{2}$ T.M. Finnegan, Letter to William W. Shin, Esq, 17 February, 1978. Available from:

www.library.ucsf.edu/tobacco/docs/html/1911.02/1911.02.1.html. Accessed: 31 October, 2008.
}

Genomics, Society and Policy, Vol.5, No.1 (2009) ISSN: 1746-5354 
${ }^{3}$ Letters from W.T. Hoyt to Henry Rothschild, 22 April, 1997 (Bates No. 11014713), 19 May, 1973 (Bates No. 11014702), 13 July, 1979 (Bates No. 11014688) and 28 January, 1980 (Bates No. 11014663). Available from: http://tobaccodocuments.org/ctr/CTRSP-FILES014694-4694.html; http://tobaccodocuments.org/ctr/CTRSP-FILES014669-4669.html; http://tobaccodocuments.org/ctr/CTRSP-FILES014644-4644.html. Accessed: 31 October, 2008. ${ }^{4}$ T.M. Finnegan, Memorandum for Messrs Greer, Henson, Holzman, Pepples, Stevens, Witt, 15 February, 1982. Available from: www.library.ucsf.edu/tobacco/docs/html/2015.02/2015.02.1.html. Accessed: 31 October, 2008.

5 "Special report, days two and three: The Waxman hearings", Tobacco Institute Newsletter, Number 301, 12 March, 1982.

${ }^{6}$ W.T. Hoyt, Letter to Henry Rothschild, 13 April, 1982. Bates No. 11022695. CTR SP-FILES 022677. Available from: http://tobaccodocuments.org/ctr/CTRSP-FILES022677-2677.html. Accessed: 31 October, 2008.

${ }^{7}$ W.T. Hoyt, Letter to Henry Rothschild, 7 June, 1983. Bates No. 11022660. CTR SP-FILES 022642. Available from: http://tobaccodocuments.org/ctr/CTRSP-FILES022642-2642.html. Accessed: 31 October, 2008.

${ }^{8}$ W.L. Ooi, R.C. Elston, V.W. Chen, J.E. Bailey-Wilson and H. Rothschild, Increased familial risk for lung cancer, Journal of the National Cancer Institute 1986: 76(2), 217-212.

${ }^{9}$ R.F. Gertenbach, Letter to Henry Rothschild, 28 August, 1986. Bates No. 11026264. CTR SP-FILES 026246. Available from: http://tobaccodocuments.org/ctr/CTRSP-FILES026246-6246.html. Accessed: 31 October, 2008.

${ }^{10}$ W.L. Ooi, R.C. Elston, V.W. Chen, J.E. Bailey-Wilson and H. Rothschild, Familial lung cancer correcting an error in calculation, Journal of the National Cancer Institute 1986: 77(4), 990.

${ }^{11}$ T.A. Sellers, W.L. Ooi, R.C. Elston, V.W. Chen, J.E. Bailey-Wilson and H. Rothschild, Increased familial risk for non-lung cancer among relatives of lung cancer patients, American Journal of Epidemiology 1987: 126(2), 237-246.

${ }^{12}$ R.F. Gertenbach, Letter to Henry Rothschild, 12 January, 1988. Available from: www.ctr-usa.org.

${ }^{13}$ T.A. Sellers, R.C. Elston, C. Stewart and H. Rothschild, Familial risk of cancer among randomly selected cancer probands, Genetic Epidemiology 1988: 5(6), 381-391.

${ }^{14}$ T.A. Sellers, R.C. Elston, L.D. Atwood and H. Rothschild, Lung cancer histologic type and family history of cancer, Cancer 1992: 69(1), 86-91.

${ }^{15}$ T.A. Sellers, J.D. Potter, J.E. Bailey-Wilson, S.S. Rich, H. Rothschild and R.C. Elston, Lung cancer detection and prevention: Evidence for an interaction between smoking and genetic predisposition, Cancer Research (Suppl.) 1992: 52, 2694s-2697s.

${ }^{16}$ Anon (undated), SRG Budget 1992; BATCo Smoking and Health Budget 1992. Bates No. 300528514-8515. Available from: http://old.ash.org.uk/html/conduct/pdfs/genetics/srg_92 bud.pdf Accessed: 31 October, 2008.

${ }^{17}$ L.J. Rudge and R.E. Thornton, Minutes of the SRG meeting, Viking Inn, Montreal, Canada, 5-7 May, 1992. Bates No. 400501290-1297. Available from: http://old.ash.org.uk/html/conduct/pdfs/genetics/srg_92.pdf. Accessed: 31 October, 2008.

${ }_{18}^{18}$ T.A. Sellers, J.E. Bailey-Wilson, J.D. Potter, S.S. Rich, H. Rothschild and R.C.Elston, Effect of cohort differences in smoking prevalence on models of lung cancer susceptibility, Genetic Epidemiology 1992: 9(4), 261-271.

${ }^{19}$ J.E. Bailey-Wilson, T.A. Sellers, R.C. Elston, C.C. Evens and H. Rothschild, Evidence for a major gene effect in early-onset lung cancer, J LA State Med Soc 1993: 145(4), 157-162.

${ }^{20}$ SRG, Minutes of the SRG meeting, Copenhagen, Denmark, 7-9 June, 1993. Bates No. 5664012591266. Available from: http://old.ash.org.uk/html/conduct/pdfs/genetics/srg_mins 93 june.pdf. Accessed: 31 October, 2008.

${ }^{21}$ SRG, Minutes of the SRG meeting, New York, US, 28-30 October, 1993. Available from: http://old.ash.org.uk/html/conduct/pdfs/genetics/srg_mins_93 oct.pdf. Accessed: 31 October, 2008. ${ }^{22}$ R.E. Thornton, Note for the Tobacco Strategy Group, 2 December, 1993. Bates No. 5025206690672. Available from: http://old.ash.org.uk/html/conduct/pdfs/genetics/srg_93.pdf. Accessed: 31 October, 2008.

${ }^{23}$ L. Rudge, BATCo memo to SRG members, 15 February, 1995. Bates No. 500833937-3947. Available from: http://old.ash.org.uk/html/conduct/pdfs/genetics/srg_95.pdf. Accessed: 31 October, 2008.

${ }^{24}$ T.A. Sellers, P.L. Chen, J.D. Potter, J.E. Bailey-Wilson, H. Rothschild and R.C. Elston, Segregation

Genomics, Society and Policy, Vol.5, No.1 (2009) ISSN: 1746-5354 
GSP Genomics, Society and Policy

online 2009, Vol.5, No.1, pp.1-54

analysis of smoking-associated malignancies: Evidence for Mendelian inheritance, American Journal of Medical Genetics 1994: 52(3), 308-314.

${ }^{25} \mathrm{NIH}$ grants and awards for fiscal year 2000: Awards in the State of Louisiana effective 03/06/2001. Available from: http://grants.nih.gov/grants/award/state/fy2000.louisian.txt. Accessed: 31 October, 2008. 


\section{S4: Genetic damage chronology}

\begin{tabular}{|c|c|}
\hline Date & Notes \\
\hline 1987 & $\begin{array}{l}\text { BAT begins funding Currie's project on p53 and lung cancer at the Marie Curie Research } \\
\text { Institute. The project receives } £ 240,000 \text { over } 8 \text { years to the end of } 1993 .{ }^{1}\end{array}$ \\
\hline 1990 & $\begin{array}{l}\text { The first paper suggesting a link between p53 mutations in lung cancer cells and tobacco } \\
\text { smoke is published (Chiba et al, 1990). }{ }^{2} \text { A copy in Philip Morris' files contains the added } \\
\text { handwritten comment "No association of p } 53 \text { mutations and smoking". }\end{array}$ \\
\hline Sep 1991 & BAT visit Graham Currie and John Jenkins at the Marie Curie Research Institute. ${ }^{4}$ \\
\hline $\begin{array}{l}\text { Undated } \\
\text { (1991) }\end{array}$ & $\begin{array}{l}\text { Field and Stell's research proposal to BAT }{ }^{5} \text {. They say that the p53 mutation pattern in lung } \\
\text { cancer adds weight to the association between smoking and lung cancer. They plan to look at } \\
\text { p53 mutations in head and neck cancers. }\end{array}$ \\
\hline Oct 1991 & Funding for Stell and Field's project begins. \\
\hline Feb 1992 & Field et al (1992). ${ }^{7}$ \\
\hline 1992 & $\begin{array}{l}\text { List of SRG research projects }{ }^{8} \text { including brief summaries of Field and Currie's projects on } \\
\text { p53 and Clausen's on adduct levels in smokers and non-smokers and the effect of dietary } \\
\text { antioxidants. }\end{array}$ \\
\hline May 1992 & $\begin{array}{l}\text { SRG meeting. }{ }^{9} \text { Notes p53 mutation spectra as an "important area". Expresses doubts about } \\
\text { Field but notes Jenkins' advice is helpful. Notes that Clausen "has found the adduct levels of } \\
\text { smokers and non-smokers to be comparable". }\end{array}$ \\
\hline Jun 1992 & $\begin{array}{l}\text { SRG visit to the Thrombosis Research Institute in London. }{ }^{10} \\
\text { "The SRG's interest in Dr Cooper's project stems from the possibility that mutations in } \\
\text { protein C (leading to various forms of thrombosis) might be similar to those in mutated } \\
\text { proteins associated with other diseases, on the basis that DNA is most likely to mutate at } \\
\text { specific sites and not at random. The extent to which the spectrum of inherited mutations that } \\
\text { arise in, for example, the p53 isolated from lung cancer cells is a matter of interest and would } \\
\text { clearly have a bearing in assessing the importance of environmental chemicals in causing } \\
\text { mutations." } \\
\text { BAT also meet Professor Kakkar, Director of the Unit. }\end{array}$ \\
\hline Jul 1992 & Field(1992). ${ }^{11}$ \\
\hline Aug 1992 & BAT funding for David Cooper's project begins. \\
\hline Aug 1992 & Skaanild and Clausen (1992). ${ }^{12}$ No funding acknowledgements. \\
\hline Mar 1993 & $\begin{array}{l}\text { Slingerland et al (1993) } .^{13} \text { John Jenkins is a co-author. } \\
\text { Emphasises the role of selection of p } 53 \text { mutations during tumour progression. } \\
\text { Acknowledges funding from the National Cancer Institute of Canada and the Medical } \\
\text { Research Council of Canada. }\end{array}$ \\
\hline Apr 1993 & $\begin{array}{l}\text { BAT funding begins for Peter Farmer's project comparing genetic damage in smokers and } \\
\text { non-smokers. }{ }^{14}\end{array}$ \\
\hline May 1993 & Field co-authors a paper which highlights the link p53 mutations and cigarette smoke. ${ }^{15}$ \\
\hline May 1993 & Spandidos et al(1993). ${ }^{16}$ Field is a co-author. \\
\hline Jun 1993 & $\begin{array}{l}\text { SRG meeting }{ }^{17} \text {. Although Cooper's project is entitled "Mutations in thrombotic disease", } \\
\text { BAT notes: "Dr Cooper is comparing the types of mutations inherited in the germline with } \\
\text { those found in p } 53 \text { genes isolated from tumour tissue. The considerable similarities suggest } \\
\text { that p53 mutation spectra are mainly dependent on the position and sequence of the DNA." }\end{array}$ \\
\hline Aug 1993 & Clausen, J (1993). ${ }^{18}$ \\
\hline
\end{tabular}




\begin{tabular}{|c|c|}
\hline $\begin{array}{l}5-6 \text { Sep } \\
1993\end{array}$ & $\begin{array}{l}\text { BAT visit to Mohr and Krawczak in Germany. } \\
\text { Records that Ulrich Mohr has now accepted the invitation to become a consultant to the SRG. } \\
\text { "Dr Krawczak works in collaboration with Dr DN Cooper (supported by BAT at the } \\
\text { Thrombosis Research Unit). } \\
\text { They are both interested in Human Genetics and met when both worked for Professor } \\
\text { Schmitke in Gottingen. Professor Schmitke has now moved to Hannover. Krawczak and } \\
\text { Cooper have shown, for example, the nucleotide sequence -C-G-is inherently unstable after } \\
\text { methylation (which occurs naturally in vertebrates)...causing a G-A transition in the } \\
\text { complementary strand. } \\
\text { They have now compared mutations in p53 derived from somatic cells (i.e. cancer derived) } \\
\text { with mutations in p53 derived from germ-line cells...88\% homology is claimed, suggesting } \\
\text { that most mutations in p53 in somatic cells are the result of genetic instability rather than } \\
\text { being caused by environmental chemicals. Unfortunately the paper on this subject submitted } \\
\text { to 'Nature' has been rejected out of hand, probably as too revolutionary. It will now be } \\
\text { submitted to 'Science.". }\end{array}$ \\
\hline Oct 1993 & $\begin{array}{l}\text { Field is lead author on a review paper discussing p53 mutations in lung cancer and head and } \\
\text { neck cancer. }{ }^{20} \text { He again contradicts BAT's position. }\end{array}$ \\
\hline Oct 1993 & $\begin{array}{l}\text { SRG meeting. }{ }^{21} \text { The SRG discuss David Cooper's research on "Mutational spectra of somatic } \\
\text { disease". "Dr Cooper compared somatic gene mutations from a database of tumour-derived } \\
\text { p53, to his own database of inherited germline mutations which are thought to arise } \\
\text { spontaneously rather than as a result of environmental factors. The distribution of mutation } \\
\text { types was found to be similar in the two databases, although G to T transversions were more } \\
\text { common in the tumour samples. Dr Cooper stated that the vast bulk of mutations are formed } \\
\text { by endogenous processes, and that it is impossible to determine the cause of a single mutation } \\
\text { in an individual." }\end{array}$ \\
\hline Dec 1993 & $\begin{array}{l}\text { BAT's RE Thornton writes a note for the Tobacco Strategy Group, summarising the SRG's } \\
\text { October meeting. } \\
\text { Thornton notes "Dr Cooper's work, originally targeted at the genetic basis of thrombotic } \\
\text { disorders had turned out to be widely applicable and relevant to a number of diseases. } \\
\text { Specifically, he was now examining the applicability of his ideas on spontaneously occurring } \\
\text { genetic mutations to cancer." }\end{array}$ \\
\hline Feb 1994 & Field applies for renewal of his SRG grant. ${ }^{23}$ \\
\hline Mar 1994 & The SRG decides that further funding for Field's project is "low priority". ${ }^{24}$ \\
\hline Jun 1994 & $\begin{array}{l}\text { Tavares et al (1994). }{ }^{25} \text { Farmer is a co-author. } \\
\text { "The [adduct] concentrations in the newborns from smoking mothers... was significantly } \\
\text { higher...than the concentrations in the newborns from non-smoking mothers." }\end{array}$ \\
\hline 1994 & Field et al (1994). ${ }^{26}$ \\
\hline Jul 1994 & $\begin{array}{l}\text { Field is a co-author on a paper which claims to have identified a new predisp } \\
\text { head and neck cancers. }\end{array}$ \\
\hline Jul 1994 & Farmer(1994). ${ }^{28}$ \\
\hline $\begin{array}{l}20-21 \text { Sep } \\
1994\end{array}$ & $\begin{array}{l}\text { SRG meeting, Hamburg. }{ }^{29} \text { Notes that Farmer's two PhD students will look at adducts and } \\
\text { oxidative damage in smokers and non-smokers. }\end{array}$ \\
\hline Jan 1995 & Field (1995)..$^{30}$ \\
\hline Feb 1995 & Summary of research projects funded by the SRG in 1995. \\
\hline $\begin{array}{l}24-25 \mathrm{Apr} \\
1995\end{array}$ & $\begin{array}{l}\text { SRG meeting, Århus. } \\
\text { "Dr Cooper would be offered a donation to his research group in return for occasional } \\
\text { presentations to the SRG on the state of current science in his field of expertise. The exact } \\
\text { nature of the contract will be discussed with Dr Cooper but may provide a basis for similar } \\
\text { arrangements with other scientists." } \\
\text { Also reports BAT's receipt of the first year report from Farmer's second PhD student. }\end{array}$ \\
\hline $\begin{array}{l}16 \text { Mar } \\
1995\end{array}$ & $\begin{array}{l}\text { Brennan et al (1995). }{ }^{32} \text { Scientists at John Hopkins Medical Center report "molecular proof } \\
\text { that smoking increases the rate of mutation" in the p53 gene". }{ }^{33} \text {. } \\
\text { The Tobacco Institute tells the Los Angeles Times "The Tobacco Institute does not have the } \\
\text { sophisticated resources necessary to evaluate research on gene mutation theories." }\end{array}$ \\
\hline
\end{tabular}




\begin{tabular}{|c|c|}
\hline 1995 & $\begin{array}{l}\text { Krawczak et al (1995). Vijay Kakkar and David Cooper, of the Thrombosis Research } \\
\text { Institute, are co-authors. } \\
\text { "...we have demonstrated here that the bulk of the spectrum of somatic single basepair } \\
\text { substitutions in the TP53 gene strongly resembles that of their germline counterparts seen in } \\
\text { other human genes...it would appear that many TP53 mutations in the soma may have arisen } \\
\text { directly or indirectly as a consequence of endogenous cellular mechanisms (perhaps } \\
\text { including those involved in DNA repair and replication) rather than through the action of } \\
\text { exogenous mutagens." } \\
\text { Funding is acknowledged from the Norwegian Cancer Association and Charter Consolidated } \\
\text { PLC. }\end{array}$ \\
\hline $\begin{array}{l}20 \mathrm{Mar} \\
1995\end{array}$ & $\begin{array}{l}\text { A BAT memo to SRG members }{ }^{35} \text { outlines the findings in Brennan et al (1995). } \\
\text { The memo claims that: "The mutations did not necessarily cause the cancer" and "Overall, in } \\
\text { our opinion this study does not establish a causal link between smoking and cancer." } \\
\text { The memo gives one reference - Krawczak et al. (1995). }\end{array}$ \\
\hline Jul 1995 & $\begin{array}{l}\text { Poulsen \& Loft (1995). The paper suggests that "oxygen species" can cause identical DNA } \\
\text { damage to external chemicals (xenobiotics), such as those in tobacco smoke. }\end{array}$ \\
\hline Dec 1995 & $\begin{array}{l}\text { Farmer(1995). }{ }^{36} \text { The paper emphasises that genetic damage (DNA adducts) could be formed } \\
\text { by internal mechanisms (endogenous processes) rather than by exposure to cancer-causing } \\
\text { chemicals. }\end{array}$ \\
\hline 1996 & $\begin{array}{l}\text { Lawrence et al (1996). }{ }^{37} \text { Farmer is a co-author. } \\
\text { Describes a method for measuring adduct levels. Funding from the UK MRC and from the } \\
\text { Commission of European Communities. }\end{array}$ \\
\hline May 1996 & $\begin{array}{l}\text { Farmer et al (1996). }{ }^{38} \text { Finds "adduct levels in smokers were significantly higher than those in } \\
\text { nonsmokers". }\end{array}$ \\
\hline Jun 1996 & $\begin{array}{l}\text { Loft \& Poulsen (1996). }{ }^{39} \text { A review of cancer risk and oxidative DNA damage. } \\
\text { The paper notes oxidative damage to DNA increases with age and that both ionizing radiation } \\
\text { and smoking can increase damage rates. Suggests protective effects from eating Brussels } \\
\text { sprouts, increasing vitamin C or eating a low-fat diet. }\end{array}$ \\
\hline Jul 1996 & Farmer et al (1996). ${ }^{40}$ \\
\hline Jul 1996 & $\begin{array}{l}\text { Lykkesfeldt et al (1996). }{ }^{41} \text { Poulsen is a co-author. } \\
\text { "These results... strongly suggest that the low ascorbic acid concentrations in [smokers"] } \\
\text { plasma related to smoking per se" [rather than diet]. } \\
\text { Acknowledges funding from BAT and the Danish Environmental Research Programme. }\end{array}$ \\
\hline Aug 1996 & $\begin{array}{l}\text { Poulsen et al (1996). "Oxidative stress to DNA points to a risk for the development of cancer } \\
\text { and premature ageing from extreme exercise." }\end{array}$ \\
\hline Jul 1998 & $\begin{array}{l}\text { Discussion Forum by Krawczak and Cooper is published in the journal Mutagenesis (of } \\
\text { which James Parry is the editor). }{ }^{2}\end{array}$ \\
\hline Aug 1998 & $\begin{array}{l}\text { Philip Morris document re Parry's "long-standing relationship" with them and his proposal } \\
\text { for future work on (i) mutation spectra and (ii) genetic susceptibility. }{ }^{43} \mathrm{PM} \text { had previously } \\
\text { funded Parry in } 1996 \text { to compare the effects of environmental hazards on the respiratory tract } \\
\text { (including passive smoking, diesel fumes and urban pollution). }{ }^{44}, 45\end{array}$ \\
\hline Nov 1998 & $\begin{array}{l}\text { Pfeifer et al (1998). }{ }^{46} \text { Response to the Mutagenesis Discussion Forum. Describes Krawczak } \\
\text { and Cooper's main argument as "erroneous and misleading". }\end{array}$ \\
\hline Mar 1999 & Farmer \& Shuker (1999). ${ }^{47}$ \\
\hline Nov 2000 & $\begin{array}{l}\text { Paschke (2000) published in Mutagenesis. }{ }^{48} \text { Claims no significant differences between p53 } \\
\text { sequences in smoking and non-smoking lung cancer patients. }\end{array}$ \\
\hline $\begin{array}{l}\text { Nov } 2000 \\
\text { to Mar } \\
2001\end{array}$ & $\begin{array}{l}\text { Exchange of letters between Hainaut and Parry regarding the failure to declare tobacco } \\
\text { funding of Paschke's research institution [Personal communication]. }\end{array}$ \\
\hline Nov 2001 & $\begin{array}{l}\text { Hainaut et al's reply to the Paschke's article }{ }^{49} \text { together with a response from Paschke }{ }^{50} \text {, are } \\
\text { published in Mutagenesis. Paschke now declares tobacco funding. }\end{array}$ \\
\hline Nov 2001 & $\begin{array}{l}\text { The last issue of Mutagenesis with Parry as editor in chief. } \\
\text { The journal adopts a new policy on conflicts of interest. }{ }^{51} \text { However, Parry remains on the } \\
\text { editorial board and also becomes acting editor of the European Journal of Genetic and } \\
\text { Molecular Toxicology. }\end{array}$ \\
\hline Jun 2002 & $\begin{array}{l}\text { Lewis et al (2002). }{ }^{53} \text { Parry is a co-author. The paper claims there is no difference in mtDNA } \\
\text { mutations between smokers and non-smokers. }\end{array}$ \\
\hline
\end{tabular}

Genomics, Society and Policy, Vol.5, No.1 (2009) ISSN: 1746-5354

(C) ESRC Genomics Network. 


\footnotetext{
${ }^{1}$ R.E. Thornton, Note for the Tobacco Strategy Group, 2 December, 1993. Bates No. 5025206690672. Available from: http://old.ash.org.uk/html/conduct/pdfs/genetics/srg 93.pdf.Accessed: 31 October, 2008. (Note, there is a discrepancy in the documents as this would imply this work was funded from 1986 not 1987.)

${ }^{2}$ I. Chiba, T. Takahashi, M.M. Nau, D. D’Amico, D.T. Curiel, T. Mitsudomi, D.L. Buchhagen, D.
} Carbone, S. Piantadosi, H. Koga et al, Mutations in the P53 gene are frequent in primary, resected nonsmall cell lung cancer, Oncogene 1990: 5(10), 1603-1610.

${ }^{3}$ Navy Medical Oncology Branch; NCI, Natl Cancer Inst; Ocogene; Ucla School of Medicine; Uniformed Services Univ of the Health SC; Lung Cancer Study Group; John Hopkins Oncology Center; Natl Naval Medical Center; D.L. Buchhagen; D. Carbone; I. Chiba; D.T. Curiel; D. D’Amico; E.C. Holmes; H. Koga; J.D. Minna; T. Mitsudomi; M.M. Nau; S. Piantadosi; P.T. Reissman; D.J. Slamon; T. Takahashi. "Mutations in the P53 gene are frequent in primary, resected non-small cell lung cancer". 19900000/P. Bates: 2028958376-2028958383. Available from: http://tobaccodocuments.org/pm/2028958376-8383.html. Accessed: 31 October, 2008.

${ }^{4}$ R.E. Thornton, Visit to Marie Curie Research Institute, Oxted, Friday 27 September. Memo, 1 October, 1991. Bates No. 300524547-4548. Available from: http://legacy.library.ucsf.edu/tid/ini27b00.

${ }^{5}$ J.K. Field and P.M. Stell, (undated), Proposal for research sponsorship from "BATS": The role of heavy smoking and drinking in association with overexpression and mutations of the P53 gene in squamous cell carcinoma of the head and neck. Bates No. 300524759-4773. Available from: http://old.ash.org.uk/html/conduct/pdfs/genetics/field p53 app.pdf. Accessed: 31 October, 2008. ${ }^{6}$ Anon (Undated), "Investigation of p53 Expression in Head and Neck Cancer". Refers to one of the applicants as JKF (John Field) and notes that Professor Stell and others will provide specimens. http://old.ash.org.uk/html/conduct/pdfs/genetics/stell_p53 rep.pdf. Accessed: 31 October, 2008. ${ }^{7}$ Field, JK, Spandidos, DA, Stell PM (1992), Overexpression of the P53 Gene in Head-and-Neck Cancer, Linked with Heavy Smoking and Drinking, The Lancet, 339, 502-503.

${ }^{8}$ SRG(1992), SRG Research Projects -1992. Bates No. 510100048-0051. Available from: http://old.ash.org.uk/html/conduct/pdfs/genetics/srg proj92.pdf. Accessed: 31 October, 2008. ${ }^{9}$ SRG, Minutes of the SRG meeting, Viking Inn, Montreal, Canada, 5-7 May, 1992. Bates No. 400501290-400501297. Available from: http://old.ash.org.uk/html/conduct/pdfs/genetics/srg 92.pdf. Accessed: 31 October, 2008.

${ }^{10}$ R.E. Thornton, Visit to the Thrombosis Research Unit (TRI), 8 June, 1992. Bates No. 40050128401285. http://old.ash.org.uk/html/conduct/pdfs/genetics/cooper thromb proj.pdf. Accessed: 31 October, 2008.

${ }^{11}$ J.K. Field, Oncogenes and tumour-suppressor genes in sqamous cell carcinoma of the head and neck, European Journal of Cancer B Oral Oncology 1992: 28B(1), 67-76.

${ }^{12}$ M.T. Skaanild and J. Clausen, Method for estimation of benzo[a]pyrene DNA adducts, Analytical Biochemistry 1992: 205, 337-341.

${ }^{13}$ J.M. Slingerland, J.R. Jenkins and S. Benchimol, The transforming and suppressor functions of p53 alleles: Effects of mutations that disrupt phosphorylation, oligomerization and nuclear translocation, The EMBO Journal 1993: 12(3), 1029-1037.

${ }^{14}$ SRG, SRG Projects 1993, Bates No. 300528414-28418. http://old.ash.org.uk/html/conduct/pdfs/genetics/srg_93proj.pdf. Accessed: 31 October, 2008. ${ }^{15}$ J.R. Gosney, S.A. Butt, M.A. Gosney and J.K. Field, Exposure to cigarette smoke and expression of the protein encoded by the 53 gene in bronchial carcinoma, Annals of the New York Academy of Science 1993: 686, 243-247.

${ }^{16}$ D.A. Spandidos, T. Liloglou and J.K. , T, Field, Prognostic significance of oncogenes and tumour suppressor genes in human malignancy, Stem Cells 1993: 11(3), 194-198.

${ }^{17}$ SRG, Minutes of the SRG meeting, Copenhagen, Denmark, 7-9 June, 1993. Bates No. 566401259566401266. http://old.ash.org.uk/html/conduct/pdfs/genetics/srg mins 93 june.pdf. Accessed: 31 October, 2008.

${ }^{18} \mathrm{~J}$. Clausen, Comparison of DNA adduct formation by means of synchronous scanning and by isotope tracers: In-vitro study on formation of DNA adducts in human lymphocytes exposed to benzo[a]pyrene, Cancer Letters 1993: 72(3), 163-167.

Genomics, Society and Policy, Vol.5, No.1 (2009) ISSN: 1746-5354 
${ }^{19}$ R.E. Thornton, Visit to Prof Dr U. Mohr, Dr M. Krawczak and Dr Koch, Medical Technical High School, Hannover, 5-6 September, 1993. Bates No: 500833681-3682. http://tobaccodocuments.org/guildford misc/500833681-3682.html. Accessed: 31 October, 2008. ${ }^{20}$ J.K. Field, Z.P. Pavelic, D.A. Spandidos, P.J. Stambrook, A.S. Jones and J.L. Gluckman, The role of the p53 tumor suppressor gene in sqamous cell carcinoma of the head and neck, Archives of Otolaryngology - Head and Neck Surgery 1993: 119, 1118-1122.

${ }^{21}$ SRG, Minutes of the SRG meeting, New York, US, 28-30 October, 1993. Bates No. 400500863400500868. Available from: http://old.ash.org.uk/html/conduct/pdfs/genetics/srg_mins 93 oct.pdf. Accessed: 31 October, 2008.

${ }^{22}$ R.E. Thornton, Note for the Tobacco Strategy Group, 2 December, 1993. Bates No. 502620669502620672. Available from: http://old.ash.org.uk/html/conduct/pdfs/genetics/srg_93.pdf Accessed: 31 October, 2008.

${ }^{23}$ T.G. Mitchell, BATCo memo to Rudge and Staines, 1 March, 1994. http://old.ash.org.uk/html/conduct/pdfs/genetics/field p53 renewal.pdf. Accessed: 31 October, 2008. ${ }^{24}$ L. Rudge, BATCo memo to Appleton et al., 16 February, 1994. http://old.ash.org.uk/html/conduct/pdfs/genetics/field p53 renewal.pdf. Accessed: 31 October, 2008. ${ }^{25}$ R. Tavares, P. Ramos, J. Palminha, M.A. Bispo, I. Paz, A. Bras, J. Rueff, P.B. Farmer and E. Bailey, Transplacental exposure to genotoxins. Evaluation in haemoglobin of hydroxyethylvaline adduct levels in smoking and non-smoking mothers and their newborns, Carcinogenesis 1994: 15(6), 1271-1274.

${ }^{26}$ J.K. Field, V. Zoumpourlis, D.A. Spandidos and A.S. Jones, P53 expression and mutations in squamous cell carcinoma of the head and neck: Expression correlates with the patients' use of tobacco and alchohol, Cancer Detection and Prevention 1994: 18(3), 197-208.

${ }^{27}$ R. Adamson, A.S. Jones and J.K.Field, Loss of heterozygosity studies on chromosome 17 in head and neck cancer using microsatellite markers, Oncogene 1994: 9(7), 2077-2082.

${ }^{28}$ P.B. Farmer, Carcinogen adducts: Use in diagnosis and risk assessment, Clin Chem 1994: 40 (7 Pt 2), 1438-1443.

${ }^{29}$ SRG, Minutes of SRG meeting, 20-21 September, 1994. Bates No. 500834084-34091. Available from: http://legacy.library.ucsf.edu/tid/eoj30a99/pdf. Accessed: 31 October, 2008.

${ }^{30}$ J.K. Field, The role of oncogenes and tumour-suppressor genes in the aetiology of oral, head and neck squamous cell carcinoma, Journal of the Royal Society of Medicine 1995: 88(1), 35P-39P.

${ }^{31}$ SRG, Minutes of the SRG meeting Árhus, 24-25 April, 1995. Bates No. 500834072-4079. **SCAN.

32 J.A. Brennan, J.O. Boyle, W.M. Koch, S.N. Goodman, R.H. Hruban, Y.J. Eby, M.J. Couch, A.A. Forastiere and D. Sidransky, Association between cigarette smoking and mutation of the p53 gene in squamous-cell carcinoma of the head and neck, New England Journal of Medicine 1995: 332(11): $712-7$.

33 "Researchers report strongest link yet between smoking, cancer", Los Angeles Times, March 16, 1995. Available from: http://legacy.library.ucsf.edu/tid/oql24a99. Accessed: 31 October, 2008.

${ }^{34}$ M. Krawczak, B. Smith-Sorensen, J. Schmidtke, V.V. Kakkar, D.N. Cooper and E. Hovig, Somatic specturm of cancer-associated single base-pair substitutions in the TP53 gene is determined mainly be endogenous mechanisms of mutation and by selection, Human Mutations 1995: 5, 48-57.

${ }^{35}$ L. Rudge, Memo to SRG members, 20 March, 1995. Bates No. 500833908-3911. Available from: http://old.ash.org.uk/html/conduct/pdfs/genetics/srg_smoke_cancer.pdf. Accessed: 31 October, 2008.

${ }^{36}$ P.B. Farmer, Monitoring of human exposure to carcinogens through DNA and protein adduct determination, Toxicol Lett 1995: 82-83,757-762.

${ }^{37}$ R.M. Lawrence, G.M.A. Sweetman, R. Tavares and P.B. Farmer, Synthesis and characterization of peptide adducts for use in monitoring human exposure to acrylonitrile and ethylene oxide,

Teratogenesis, Carcinogenesis, and Mutagenesis 1996: 16, 139-148.

${ }^{38}$ P.B. Farmer, R. Cordero and H. Autrup, Monitoring human exposure to 2-hydroxyethylating carcinogens, Environmental Health Perspectives 1996: 104 Suppl 3, 449-452.

${ }^{39}$ S. Loft and H.E. Poulsen, Cancer risk and oxidative DNA damage in man, Journal of Molecular Medicine 1996: 74(6), 297-312.

${ }^{40}$ P.B. Farmer, O. Sepai, R. Lawrence, H. Autrup, P. Sabro Nielsen et al, Biomonitoring human exposure to environmental carcinogenic chemicals, Mutagenesis 1996: 11(4), 363-381.

${ }^{41}$ J. Lykkesfeldt, H. Prieme, S. Loft and H.E. Poulsen, Effect of smoking cessation on plasma ascorbic acid concentration, British Medical Journal 1996: 313, 91.

${ }^{42}$ M. Krawczak and D.N. Cooper, P53 mutations, benzo[a]pyrene and lung cancer, Mutagenesis 1998: 13 (4), 319-320.

Genomics, Society and Policy, Vol.5, No.1 (2009) ISSN: 1746-5354

(C) ESRC Genomics Network. 
${ }^{43}$ A.R. Tricker, Memo to the SRRC, Scientific Affairs EU/EEMA Regions, Re: Bioinformatics, applications in the identification of the significance of genotoxic activity in cancer induction and progression and in the identification of susceptibility to genotoxins. Proposal submitted by Professor James M. Parry, University of Wales, Swansea, Swansea, United Kingdom, 8 August, 1998. http://old.ash.org.uk/html/conduct/pdfs/genetics/mutagenesis/parry pm.pdf. Accessed: 31 October, 2008.

${ }^{44}$ Philip Morris USA, "External Research Scientific Affairs Eu / Eema Region". 29 October, 1996. Bates: 2063610966-2063611011. http://tobaccodocuments.org/pm/2063610966-1011.html. Accessed: 31 October, 2008.

${ }^{45}$ Philip Morris [No title], 22 August. 1994. Bates: 2050740972-2050741002. http://tobaccodocuments.org/pm/2050740972-1002.html. Accessed: 31 October, 2008.

${ }^{46}$ G.P. Pfeifer, M.F. Denissenko and M-S. Tang, P53 mutations, benzo[a]pyrene and lung cancer: A reply, Mutagenesis 1998: 13 (6), 537-538.

${ }^{47}$ P.B. Farmer and D.E. Shuker, What is the significance of increases in background levels of carcinogen-derived protein and DNA adducts? Some considerations for incremental risk assessment, Mutation Research 1999: 424(1-2), 275-286.

${ }^{48} \mathrm{~T}$. Paschke, Analysis of different versions of the IARC p53 database with respect to GT transversion mutation frequencies and mutation hotspots in lung cancer of smokers and non-smokers, Mutagenesis 2000: 15 (6): 457-458. Available from:

http://old.ash.org.uk/html/conduct/pdfs/genetics/mutagenesis/paschke discussion.pdf. Accessed: 31 October, 2008.

${ }^{49}$ P. Hainaut, M. Olivier and G.P. Pfeifer, TP53 mutation spectrum in lung cancers and mutagenic signature of components of tobacco smoke: Lessons from the IARC TP53 mutation database, Mutagenesis 2001: 16 (6), 551-553.

${ }^{50}$ T. Paschke, Reply to the contribution of Hainaut, Olivier and Pfeifer (TP53 mutation spectrum in lung cancers and mutagenic signature of components of tobacco smoke: Lessons from the IARC TP53 mutation database), Mutagenesis 2001: 16(6), 555-556.

${ }^{51}$ Available from: http://www3.oup.co.uk/jnls/list/mutage/edboards. Accessed: 31 October, 2008.

${ }_{52}^{52}$ Available from: http://www.swan.ac.uk/cget/ejgt1.htm. Accessed: 31 October, 2008.

${ }^{53}$ P.D. Lewis, S.R. Fradley, A.P. Griffiths, P.W. Baxter and J.M. Parry, Mitochondrial DNA mutations in the parotid gland of cigarette smokers and non-smokers, Mutation Research 2002: 518(1), 47-54. 